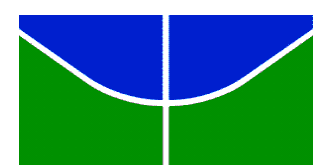

Universidade de Brasília

Faculdade de Ciências da Saúde

Departamento de nutrição

Programa de Pós-Graduação em Nutrição Humana

Guilherme Theodoro de Oliveira

CARACTERIZAÇÃO DE FARINHAS DE DIFERENTES GENÓTIPOS DE SORGO E EFEITO DA PANIFICAÇÃO NOS TEORES DE AMIDO RESISTENTE E ANTIOXIDANTES

Brasília

2016 
Guilherme Theodoro de Oliveira

\section{CARACTERIZAÇÃO DE FARINHAS DE DIFERENTES GENÓTIPOS DE SORGO E EFEITO DA PANIFICAÇÃO NOS TEORES DE AMIDO RESISTENTE E ANTIOXIDANTES}

Dissertação apresentada ao Programa de PósGraduação em Nutrição Humana da Universidade de Brasília, como requisito para obtenção do grau de Mestre em Nutrição Humana.

Orientador:

Professora Doutora Lívia Lacerda de Oliveira Pineli

Coorientador:

Professor Lúcio Flávio de Alencar Figueiredo

Brasília

2016 


\section{Guilherme Theodoro de Oliveira}

\section{CARACTERIZAÇÃO DE FARINHAS DE DIFERENTES GENÓTIPOS DE SORGO E EFEITO DA PANIFICAÇÃO NOS TEORES DE AMIDO RESISTENTE E ANTIOXIDANTES}

Dissertação apresentada ao Programa de PósGraduação em Nutrição Humana da Universidade de Brasília, como requisito para obtenção do grau de Mestre em Nutrição Humana.

Aprovada em:

MEMBROS DA BANCA

Doutora Lívia Lacerda de Oliveira Pineli

(Presidente da Banca - Programa de Pós-Graduação em Nutrição Humana)

Professora Doutora Raquel Braz Assunção Botelho (Membro Interno - Universidade de Brasília)

Professora Doutora Valéria Aparecida Vieira Queiroz (Membro Externo - Embrapa Milho e Sorgo)

Professora Doutora Renata Puppin Zandonadi (Suplente - Universidade de Brasília)

Brasília 
Oliveira, Guilherme Theodoro.

Caracterização de farinhas de diferentes genótipos de sorgo e efeito da panificação nos teores de amido resistente e antioxidantes.

Dissertação de mestrado / Programa de Pós-Graduação em Nutrição Humana, Universidade de Brasília, 2016.

Área de Concentração: Nutrição Humana

Orientador: Lívia Lacerda de Oliveira Pineli

Co-orientador: Lúcio Flávio de Alencar Figueiredo

1 - Sorgo 2 - Panificação 3 - Antioxidantes 4 - Nutrição 5 - Amido Resistente 6 - Centesimal 
Para Márcia, Gabriel e Giselle, por todo o apoio durante esse processo. 


\section{AGRADECIMENTOS}

À professora Lívia Pineli e ao professor Lúcio Figueiredo por acreditarem em meu potencial. Mesmo com tantas atribuições, estiveram disponíveis e dispostos a ajudar. Com eles aprendi a buscar mais que resultados, a ser um pesquisador. São referências profissionais e pessoais para meu crescimento. Obrigado por tudo!

A todos os funcionários dos departamentos de Nutrição, Botânica e Agronomia da Universidade de Brasília, por me ajudarem ativa e passivamente nesse projeto.

Ao técnico Marcos Sodré do laboratório de Ciência e Tecnologia de Alimentos da Universidade Católica de Brasilia pelas orientações e amizade imprescindíveis

Também agradeço a toda equipe da área de Alimentos da Embrapa Milho e Sorgo de Sete Lagoas em especial à Dr. Valéria Vieira e ao pessoal da Embrapa Cerrados de Planaltina com destaque à professora Sônia Celestino, pelo paoio das análises de fibras.

Agradeço à CAPES e à FAP/DF e à Embrapa pelo apoio financeiro.

Por último e não menos importante, gostaria de agradecer ao Programa de PósGraduação em Nutrição Humana por abrirem as portas para que eu pudesse realizar esse sonho.

MUITO OBRIGADO A TODOS! 


\section{RESUMO}

A alta incidência mundial de casos com reações adversas relacionadas ao glúten tem aumentado a demanda por novas fontes alternativas de insumos com qualidade nutricional e tecnológica para a produção de alimentos. Dentre essas alternativas destaca-se o sorgo (Sorghum bicolor. L. Moench), quinto cereal mais produzido no mundo, que apresenta elevada qualidade do ponto de vista nutricional, alta variabilidade genética no que se refere a quantidades de compostos antioxidantes e de amido resistente. Esses podem promover benefícios à saúde, reduzindo o risco de desenvolvimento de doenças crônicas não transmissíveis. Dessa forma, o presente estudo visa avaliar a composição nutricional, assim como compostos bioativos e atividade antioxidante de cinco genótipos de sorgo e uma farinha comercial. Primeiramente, foram avaliados os grãos dos genótipos quanto à sua vitreosidade e peso em 1000 grãos. Posteriormente, foram produzidas farinhas e uma formulação de pão sem glúten com cada genótipo mais o comercial. Foram realizadas análises de umidade, cinzas, proteína bruta, lipídeos, fibra solúvel e insolúvel, amido resistente e amido solúvel, teor de amilose, fenólicos totais, taninos totais e atividade antioxidante por DPPH $\left(\mathrm{IC}_{50}\right)$ e FRAP, tanto nas farinhas quanto nos pães elaborados. Pôde-se observar que as amostras de farinha e pão provenientes do genótipo classificado como testa marrom com tanino BR 305 apresentaram maiores teores de compostos fenólicos (1493 e $469 \mathrm{mg} / 100 \mathrm{~g} \mathrm{MF}$, respectivamente $)$ e taninos $(609,9$ e $188 \mathrm{mg}$ de proantocianidina $/ 100 \mathrm{~g}$ MF, respectivamente), além de maior concentração de amido resistente $(3,8 \mathrm{~g} / 100 \mathrm{~g}$ e $2,4 \mathrm{~g} / 100 \mathrm{~g} \mathrm{MF}$, respectivamente), representando um potencial interessante para a formulação de pães sem glúten do ponto de vista nutricional. Com relação ao teor de amilose nas farinhas, a amostra 116748 apresentou maior fração, com $22,8 \%$. Os teores de umidade $(12,5-14,7 \mathrm{~g} / 100 \mathrm{~g})$, cinzas $(1,02-1,53 \mathrm{~g} / 100 \mathrm{~g})$, proteínas $(8,59-9,54 \mathrm{~g} / 100 \mathrm{~g})$ e lipídeos $(2,14$ - 4,66g/100g) obtiveram pequena variação entre as farinhas. Observou-se uma correlação positiva entre os compostos bioativos e fibras, além de amilose, com vitreosidade. Concluiu-se que existe diferença nas características entre distintos genótipos de sorgo quanto à presença e à atividade de compostos bioativos. Além disso, o processamento térmico tende a diminuir a concentração desses compostos. No entanto, mais estudos devem ser feitos para uma avaliação mais aprofundada objetivando-se também aspectos tecnológicos e sensoriais desta variação. 


\begin{abstract}
The high incidence worldwide of cases with adverse reactions related to gluten has increased the demand for alternative sources of inputs with nutritional and technological quality for food production. Among these alternatives highlight the sorghum (Sorghum bicolor. L. Moench), fifth most cereal produced in the world that has a high quality nutritional point of view, high genetic variability as regards the amounts of antioxidants and resistant starch . These can promote health benefits, reducing the risk of developing chronic diseases. Thus, this study aims to evaluate the nutritional composition, as well as bioactive compounds and antioxidant activity of five genotypes of sorghum and a commercial flour. First, we evaluated the grains of genotypes for their vitreousness and weight of 1000 grains. Subsequently, flours were produced and gluten-free bread formulation with increasingly commercial genotype. moisture analyzes were performed, ash, protein, lipids, soluble and insoluble fiber, resistant starch and soluble starch, amylose content, total phenolics, total tannins and antioxidant activity by DPPH $\left(\mathrm{IC}_{50}\right)$ and FRAP, both in flour as in breads elaborate. It was observed that samples of flour and bread coming from the rated as genotype tests with brown tannin BR 305 showed higher levels of phenolics (1493 and $469 \mathrm{mg} / 100 \mathrm{~g} \mathrm{MF}$, respectively) and tannins (609.9 to $188 \mathrm{mg}$ proanthocyanidin/100g MF, respectively), besides higher concentrations of resistant starch (3.8 and 2.4g / 100g MF, respectively), an interesting potential for the formulation of gluten-free breads nutritional point of view. Regarding the amylose content in flour, sample 116748 showed a higher fraction, with $22.8 \%$. The moisture content $(12.5-14,7 \mathrm{~g} / 100 \mathrm{~g})$, ash $(1.02-1.53 \mathrm{~g} / 100 \mathrm{~g})$, proteins $(8,59-9,54 \mathrm{~g} / 100 \mathrm{~g})$ and lipids $(2.14-466 \mathrm{~g} / 100 \mathrm{~g})$ showed little variation between meals. There was a positive correlation between the fibers and bioactive compounds, and amylose, with vitreousness. It was concluded that there is a difference in characteristics between different genotypes of sorghum for the presence and activity of bioactive compounds. Moreover, heat processing tends to reduce the concentration of these compounds. However, more studies should be done to further evaluation also aiming up technological and sensory aspects of variation.
\end{abstract}




\section{LISTA DE FIGURAS}

Figura 1 - Formação do Glúten na farinha de Trigo............................................... 17

Figura 2 - Produção mundial de sorgo em 2014.....................................................22

Figura 3 - Principais países produtores mundiais de sorgo em 2014 ...................... 23

Figura 4 - Variedades de sorgo com distintas colorações.....................................24

Figura 5 - Teste de receita de pão sem glúten....................................................... 30

Figura 6 - Regressão PLS da composição das farinhas de sorgo e das características físicas dos grãos (vitreosidade e massa de 100 grãos). .49 


\section{LISTA DE TABELAS}

Tabela 1 - Tipo de grão e características do pericarpo dos genótipos utilizados...... 29

Tabela 2 - Proporção dos ingredientes da receita padrão do pão de sorgo............... 31

Tabela 3 - Característica visual e valores de vitreosidade e peso de 100 grãos dos grãos

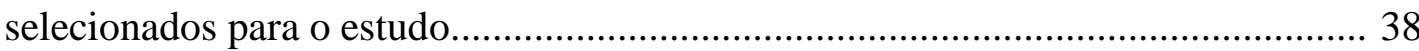

Tabela 4 - Valores de composição, compostos bioativos e atividade antioxidante das farinhas elaboradas em comparação com a comercial. 43

Tabela 5 - Valores de composição estimada, compostos bioativos e atividade antioxidante dos pães elaborados em comparação com o pão comercial..... .48

Tabela 6 - Relação entre as variáveis resposta e as variáveis independentes de vitreosidade (\%) e massa de 1000 grãos $(\mathrm{g})$. 51 


\section{LISTA DE ANEXOS}

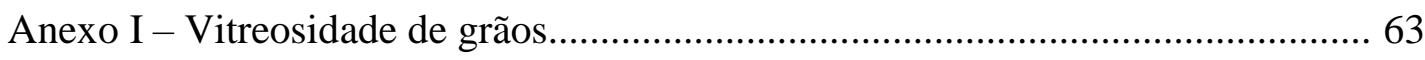

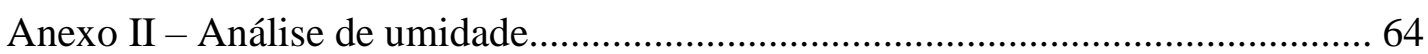

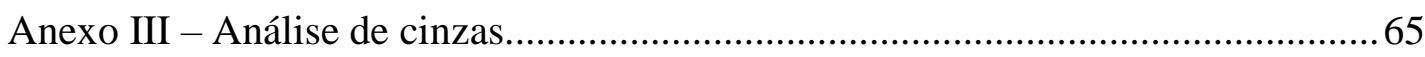

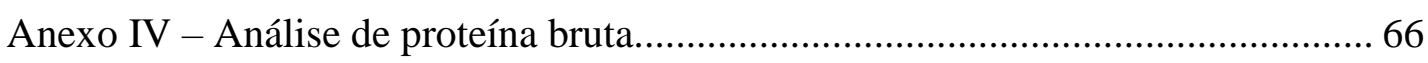

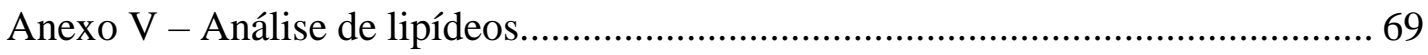

Anexo VI - Análise de fibra alimentar............................................................ 71

Anexo VII - Análise de amido resistente, solúvel e total.......................................78

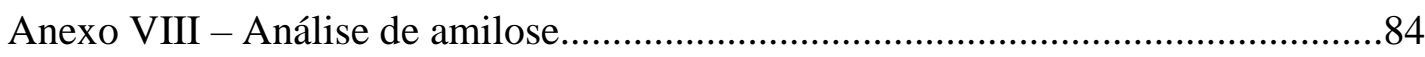

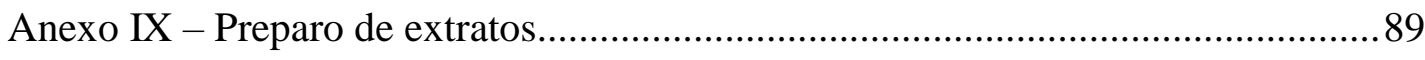

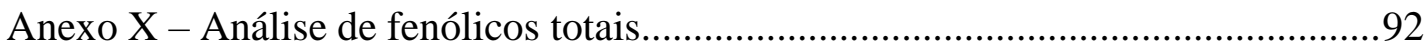

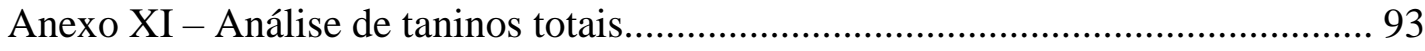

Anexo XII - Atividade antioxidante por DPPH.................................................. 95

Anexo XIII - Atividade antioxidante por FRAP................................................. 98 


\section{SUMÁRIO}

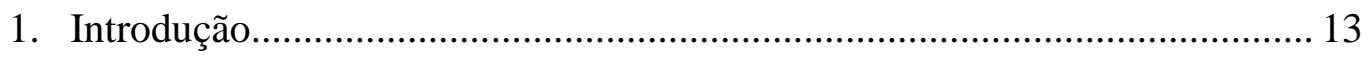

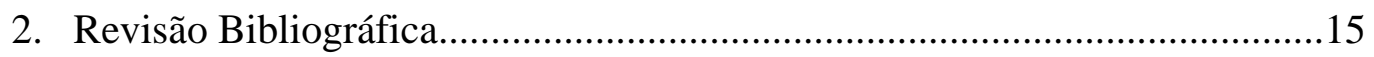

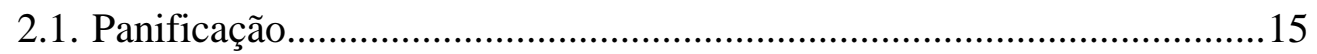

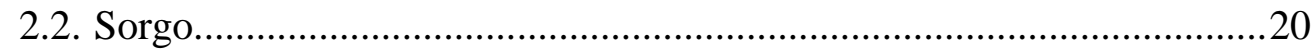

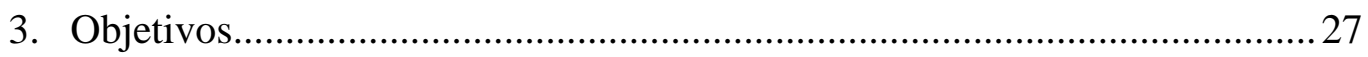

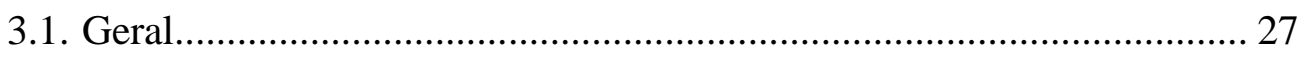

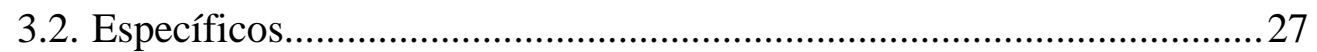

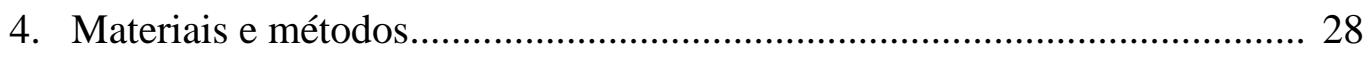

4.1. Elaboração e caracterização das farinhas de sorgo ............................ 28

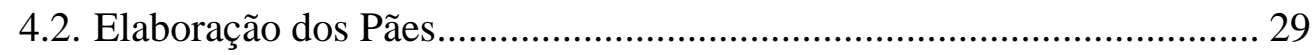

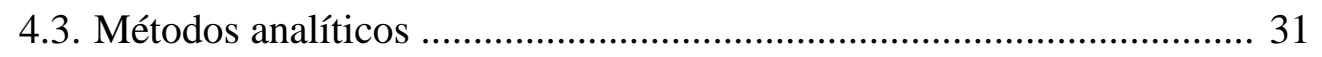

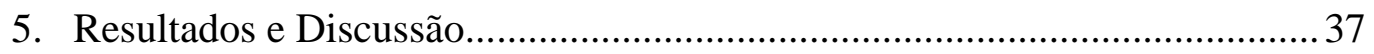

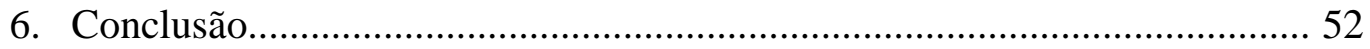

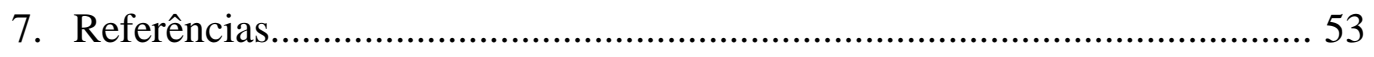

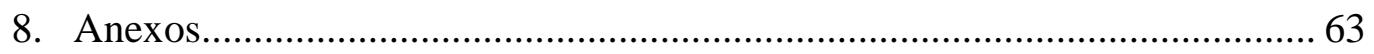

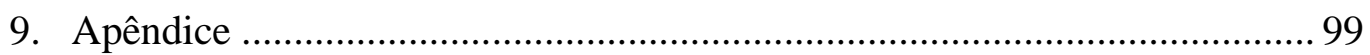




\section{INTRODUÇÃO}

A alta incidência mundial de casos com reações adversas relacionadas ao glúten tem aumentado a demanda por novas fontes alternativas de insumos com qualidade nutricional e tecnológica para a produção de alimentos (FASANO et al., 2008). A substituição da farinha de trigo das preparações por outros farináceos acarreta mudanças sensoriais nos alimentos modificando seu sabor, textura, hidratação e aparência podendo levar a baixos teores de micronutrientes e fibras (ANDRADE et al., 2011).

Além disso, o tratamento das reações adversas ao glúten consiste, principalmente, na adoção de uma dieta isenta de glúten que representa uma drástica mudança no estilo de vida dos pacientes. Por adotarem uma dieta rigorosa durante toda a vida, essas pessoas são obrigadas, muitas vezes, a retirar de sua alimentação produtos como pães, bolos e biscoitos. Estas restrições, consequentemente, levam a uma característica monotonia alimentar (PEREIRA et al., 2013).

Dentre os insumos utilizados para a preparação de produtos isentos de glúten o sorgo pode ser uma alternativa interessante. O sorgo (Sorghum bicolor. L. Moench) é o quinto cereal mais produzido no mundo, entretanto, apenas $35 \%$ dessa produção é utilizada para a alimentação humana (MUTISYA et al., 2009). É reponsável por até $70 \%$ da ingestão calórica de algumas comunidades na África, assim como importante ingrediente de preparações na Índia (EMBRAPA, 2009). Apresenta elevada qualidade do ponto de vista nutricional, sendo basicamente comparável ao milho e ao trigo

(ANGLANI, 1998). Além disso, sua elevada variabilidade genética possibilita a existência de grãos com quantidades superiores de antioxidantes e de amido resistente (DICKO et al., 2006). 
Os antioxidantes podem promover benefícios à saúde, reduzindo o risco de desenvolvimento de doenças crônicas não transmissíveis, devido a sua capacidade de neutralizar os radicas livres. Dessa forma, inibe-se a oxidação de lipídios de membrana, proteínas e carboidratos garantindo o correto funcionamento do organismo. Em longo prazo, previne-se o aparecimento de doenças crônicas, principalmente associadas ao envelhecimento, destacando-se o câncer, a aterosclerose e as doenças inflamatórias (HARBONNE \& WILLIANS, 2000; LIU, 2003; SEIFRIED et al., 2007).

Um estudo de revisão realizado por Pineli et al. (2015) avaliou a utilização do sorgo na produção de pães comerciais. Foi observado que, geralmente, dentre pesquisas envolvendo esse cereal para a panificação são poucos estudos que avaliam sua diversidade acerca de seu potencial antioxidante e demais compostos bioativos.

Dessa forma, o presente estudo visa caracterizar química e nutricionalmente cinco genótipos de sorgo com características fenotípicas variadas (pericarpo branco, bronze e marrom, com e sem taninos) e o efeito do processamento de panificação sobre os nutrientes e os compostos bioativos. 


\section{REVISÃO BIBLIOGRÁFICA}

\subsection{Panificação}

A panificação é considerada como uma das artes culinárias mais antigas da humanidade. Teve papel de destaque na estrutura de importantes civilizações como o antigo Egito, o Império Romano e ainda hoje está fortemente presente na produção alimentícia mundial (FLANDRIN et al., 1998; REVISTA-FI, 2009).

Desde a antiguidade o preparo de pães sempre esteve associado ao plantio do trigo. Essa cultura foi a principal responsável pelo surgimento da agricultura na região do Crescente Fértil, considerada como berço da civilização. No período de 8.000 a.C a 600 d.C, o pão já era elaborado na região da Mesopotâmia. Produzido com grãos triturados rusticamente à base de trigo e outros cereais como cevada e aveia, tinha um formato oval e achatado característico. Esses pães, posteriormente, denominados em inglês por flatbreads, foram os únicos conhecidos pelas civilizações por milênios (RAE, 2008; REVISTA-FI, 2009).

O processo de produção do pão sofreu incontáveis mudanças a partir de sua incorporação a outras culturas. Foi no Egito antigo que a panificação se transformou definitivamente com o desenvolvimento de técnicas para a moagem de grãos e a implementação do processo de fermentação o qual contribuiu para melhores características tecnológicas, principalmente maior maciez (REVISTA-FI, 2009).

Mais tarde, em Roma, conquistou rapidamente todos os extratos da sociedade. Nesse período, tornou-se tão importante na estrutura do império, que obteve papel central no controle social da época. A política do "Pão e Circo" (Panem et circenses originalmente em Latim) constituiu-se em uma prática clientelista onde havia a troca de 
alimentação e entretenimento pelo consentimento da forma de governo vigente (GONÇALVES, 2007).

Com o desenvolvimento das relações de Estado, a utilização da farinha de trigo como principal ingrediente na formulação de pães fortificou-se na Europa entre os séculos X e XIV durante a Idade Média. Nesse período, o trigo adquiriu uma conotação relacionada à "hierarquia do gosto" onde os mais ricos consideram o pão branco como sendo o único à altura de seu nível social, o que acabou impulsionando uma elevação exponencial em sua área cultivável, principalmente na região da Itália (FLANDRIN et al., 1998).

O status que a panificação alcançou na constituição alimentar das culturas da época pôde ser avaliado na ocorrência de episódios como o ocorrido na França em 1775. A chamada "Guerra da Farinha" foi resultado do descontentamento popular frente ao programa econômico do então ministro das finanças Jacques Turgot, que aumentou o preço do pão para evitar a escassez do trigo no mercado interno (FREIXA et al., 2008; GALLO, 2012).

Esses fatores históricos demonstram o papel fundamental da panificação na alimentação. Pela sua importância, essa atividade, até então considerada artesanal, foi uma das primeiras a passar pelo processo de mecanização oriundo da revolução industrial. As principais alterações que influenciaram expressivamente na sua cadeia produtiva foram as fases de amassadura e cozimento, em 1925 (FLANDRIN et al., 1998; FREIXA et al., 2008).

Esse processo consolidou, durante muitos anos, o que podemos chamar de composição mínima do pão como sendo a junção de água, sal e fermento biológico com 
a farinha de trigo. Cada um desses ingredientes possuiu importância tecnológica ao preparo, com destaque à farinha de trigo por se tratar de ser o componente estrutural.

A cultura do trigo sofreu grandes modificações durante seu processo de domesticação. O desenvolvimento tecnológico das espécies selvagens culminou atualmente, em apenas duas espécies que são largamente produzidas mundialmente: Triticum aestivum (trigo comum) e Triticum vulgare (trigo duro), sendo o primeiro responsável por $90 \%$ da produção (PIANA et al., 2008).

O trigo é composto basicamente de carboidratos $(\sim 82 \%)$ e proteínas $(\sim 10 \%)$. Particularmente, sua composição proteica possui elevada importância tecnológica na panificação. Suas proteínas podem ser classificadas de acordo com a solubilidade em: gluteninas, gliadinas, albuminas e globulinas. Desse conjunto destacam-se as gliadinas e a globulinas que ao serem hidratadas e sobre energia mecânica, formam uma massa viscoelástica denominada glúten, que permite proporcionar volume e crocância às preparações (ARAÚJO et al., 2007; FENNEMA, 2010).

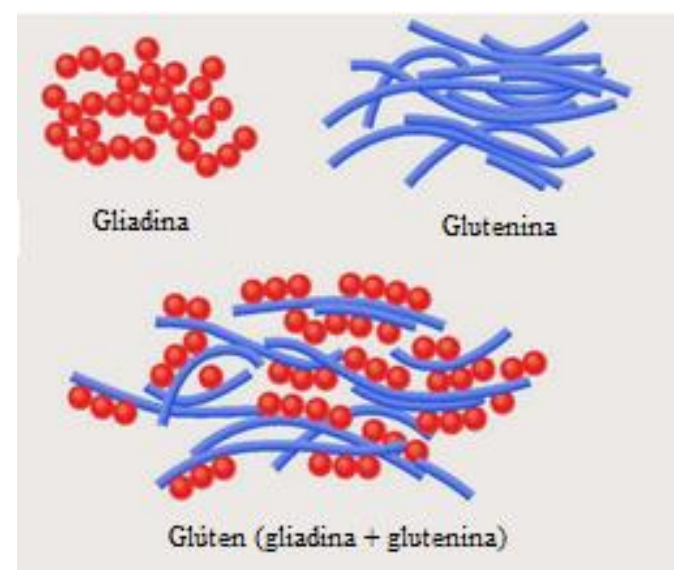

Figura 1: Formação do Glúten na farinha de Trigo Fonte: Produto alimentício, 2013 
Trata-se de uma mistura heterogênea de peptídeos específicos (Figura 01) que, além do trigo, também podem ser encontrados em outros cereais como a cevada (secalina), aveia (avenina) e o centeio (hordeína).

Essas moléculas são incapazes de sofrer hidrólise completa por enzimas digestivas humanas podendo ativar uma resposta inflamatória inapropriada do organismo contra a mucosa do indivíduo, resultando em um quadro sintomático devido a uma das várias reações adversas ao glúten, dentre as quais estão as alergias, a sensibilidade ao glúten ou a doença celíaca (SAPONE et al., 2012). Esse quadro compromete as funções secretoras, digestivas e absortivas do indivíduo comprometendo seu metabolismo (STERN et al., 2001; GRENN et al., 2003; FASANO et al., 2008; KRAUSE, 2010; CRESPO PÉREZ et al., 2012).

Atualmente, as reações adversas ao glúten estão entre as mais comuns do mundo com prevalência mundial de aproximadamente $10 \%$ da população mundial (FASANO et al., 2003). Acomete, principalmente, indivíduos brancos do gênero feminino. Nesse grupo sua ocorrência mais agressiva ao organismo, responsável por $1 \%$ dos casos, é denominada de Enteropatia Sensível ao Glúten, ou mais popularmente de Doença Celíaca (ACELBRA, 2004).

Seu tratamento consiste na exclusão de preparações que contenham ingredientes com glúten da dieta do paciente. Objetiva-se, dessa maneira, a melhora das alterações fisiopatológicas intestinais favorecendo a absorção de nutrientes para recuperar o estado nutricional do paciente (ARAÚJO, 2008). No entanto, a sua remoção da alimentação dos pacientes é uma tarefa de difícil realização, pois preparos com ingredientes que contenham glúten, dentre os quais principalmente o trigo, são consumidos amplamente 
pela população mundial e podendo estar presentes em todas as refeições do indivíduo (ARAÚJO et al., 2010; SAPONE et al., 2012).

Dentre as preparações com maior importância de adaptação para o público com reações adversas ao glúten, o pão constitui-se um alimento de elevada importância cultural em todo o mundo, e o de maior complexidade para adaptação à ausência de glúten. No Brasil, os poucos pães sem glúten encontrados no mercado, em sua maioria não possuem boa qualidade tecnológica, apresentando baixo volume, esfarelamento do miolo e cor pálida (MATOS et al., 2011).

Uma pesquisa realizada em 2012 pela Associação dos Celíacos do Brasil demonstrou que $47 \%$ dos entrevistados apresentou preferência na maior disponibilidade de produtos de panificação seguido por massas com 21\% (ACELBRA, 2012).

De acordo com a legislação brasileira, o pão é o produto obtido pela cocção de uma massa fermentada ou não, preparada com farinha de trigo e/ou outras farinhas que contenham naturalmente proteínas formadoras de glúten, ou adicionadas destas, e água, podendo conter outros ingredientes (ANVISA, 2000).

É desafiadora a substituição do trigo por outros produtos amiláceos sem glúten na panificação. Atualmente, o principal produto utilizado para tal é o arroz. Sua farinha é uma alternativa interessante, pois é hipoalergência, possui sabor suave, coloração branca e boa digestibilidade (SIVARAMAKRISHNAN et al., 2004). Entretanto, por não apresentar em sua constituição proteínas formadoras de glúten, não consegue gerar uma estrutura que mantenha as mesmas características de quando utilizado o trigo (ALMEIDA, 2011). Para suprir essa necessidade tem-se pesquisado a adição de ingredientes como hidrocoloides, emulsificantes, produtos lácteos, proteínas, amido gelatinizado e enzimas, pois busca-se desenvolver uma estrutura similar à rede de glúten 
para manter o gás carbônico produzido na fermentação garantindo volume e crocância adequadas (RAMOS et al., 2011).

$\mathrm{Na}$ busca de outras alternativas mais interessantes para a substituição do trigo nas preparações culinárias, principalmente na panificação, a farinha de sorgo tem se apresentado como promissora, pois sua elevada diversidade e variabilidade genética possibilita a elaboração de farinhas com diferentes nutrientes. Além de possuir sabor suave, os níveis de amido resistente e diferentes teores de amilose e amilopectina, estão relacionadas com a capacidade de geleificação e solubilidade da farinha podendo apresentar-se como importante papel na substituição do glúten nas preparações (LELOUP et al., 1991; CIACCI et al., 2007; PONTIERI et al., 2013).

\subsection{Sorgo}

A constante busca por substitutos ao trigo em preparações culinárias destinados à população com sensibilidade ao glúten permitiu o resgate de diferentes culturas com potencial para alimentação humana. Dentre estas destaca-se o sorgo (Sorghum bicolor L. Moench) por suas características nutricionais, de produtividade e de maior resistência à seca (EMBRAPA, 2009).

Trata-se de uma cultura utilizada no preparo de alimentos desde a antiguidade. Registros arqueológicos sobre sua produção datam desde 3.000 a.C. na região hoje conhecida como Etiópia, época em que houve a introdução e o cultivo de cereais no Antigo Egito (HARLAN et al., 1972; EMBRAPA, 2009).

Foi introduzido no Ocidente em meados do século XIX, sendo utilizado, quase que exclusivamente, como substituto do milho na alimentação animal. No Brasil, sua 
introdução ocorreu em meados do século XX no Sudeste, sendo hoje, cultivado principalmente no Centro Oeste (EMBRAPA, 2009).

O sorgo, assim como outros cereais de elevada importância para o preparo de alimentos (trigo, milho e arroz), pertence à família Poaceae, do gênero Sorghum e caracteriza-se por possuir raízes profundas e ramificadas com grande quantidade de pelos absorventes, o caule alto e espesso dividido em nós e entrenós e folhas lineares, compridas e largas, semelhantes às do milho ao longo de toda a planta (EMBRAPA, 2009).

É considerado resistente à seca, pois envolve simultaneamente os mecanismos de escape e tolerância oriundos de aspectos fisiológicos, bioquímicos e morfológicos. O escape está relacionado com suas raízes características que lhe conferem eficiente captação de água do solo e a tolerância devido à capacidade de modificar o metabolismo para melhor tolerar períodos de estresse (EMBRAPA, 2009).

O sorgo possui qualidade nutricional semelhante ao milho e ao trigo variando de acordo com as condições ambientais existentes durante o cultivo (WANISKA, 2000). Possui quantidades aproximadas de 65 a $80 \%$ de carboidratos, 7 a 15\% de proteínas, 1,5 a 6\% de lipídeos, 1 a 4\% de minerais e umidade entre 8 e $12 \%$ (DICKO et al., 2006).

Atualmente, é o quinto cereal mais produzido no mundo com, aproximadamente, 67,9 milhões de toneladas, após o milho (Zea mays L.) - 1 bilhão de toneladas, arroz (Oryza sativa L.) - 741 milhões de toneladas, trigo (Triticum aestivum L.) - 729 milhões de toneladas e a cevada (Secale cereale L.) - 144 milhões de toneladas (FAOSTAT,2014). 


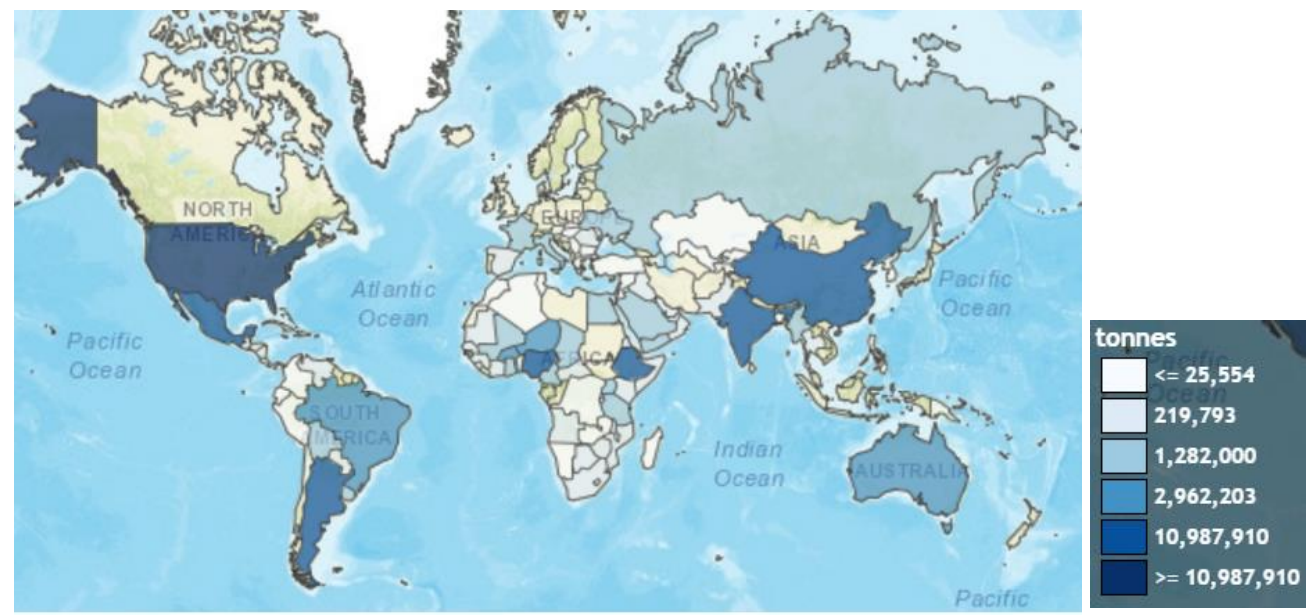

Figura 2: Produção mundial de sorgo em 2014

Fonte: http://faostat3.fao.org

No mundo apenas $35 \%$ de sua produção são destinados para alimentação humana. Mais de 500 milhões de pessoas utilizam o sorgo como alimento base chegando a $70 \%$ da constituição do valor calórico diário em determinadas localidades. Os principais produtos comercializados nessas regiões são pães, tortilhas, cervejas, cuscuz e snacks (MUTISYA et al, 2009).

O Brasil foi o décimo maior produtor mundial em 2014 com aproximadamente 2,3 milhões de toneladas. Sua produção está concentrada nas regiões Sudeste, Sul e Centro-Oeste, mas devido a planta ser altamente adaptativa, principalmente, sob condições de deficiência hídrica, desfavoráveis à maioria dos outros cereais, permite que a cultura seja apta para desenvolvimento e expansão em regiões de cultivo com distribuição irregular de chuvas e em sucessão a culturas de verão (FAOSTAT,2014) como na região do nordeste brasileiro. 


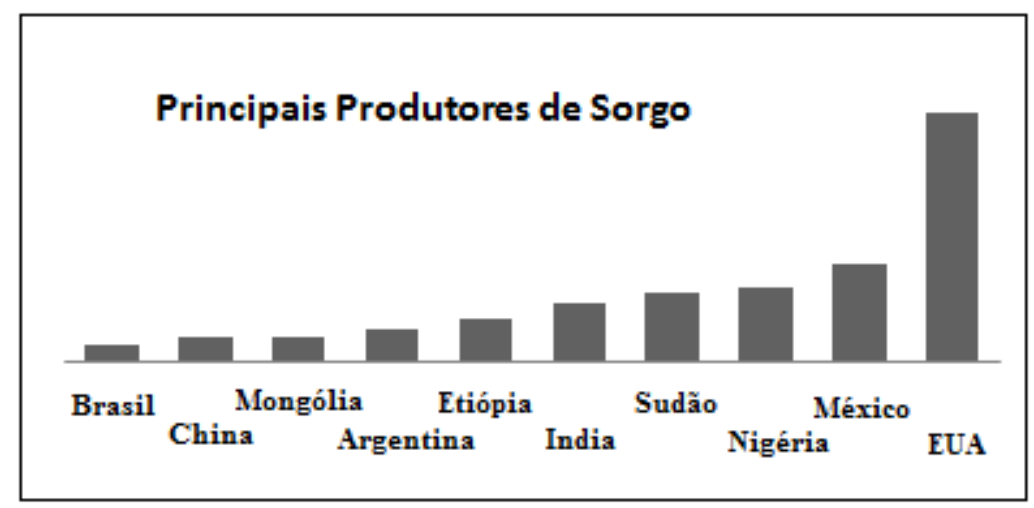

Figura 3: Principais países produtores mundiais de sorgo em 2014

Fonte: http://faostat3.fao.org

A utilização do sorgo para a alimentação humana tem elevado potencial, pois trata-se de uma cultura relativamente barata em relação a outros cereais. Quando comparado ao milho, sua substituição pela farinha de sorgo apresenta uma redução de até $15 \%$ no preço das preparações culinárias (HANCOCK, 2000; MUTISYA et al., 2009). Porém em alguns países, como o Brasil, ele é utilizado quase que exclusivamente para alimentação animal.

Para mudar esse quadro a unidade da Embrapa milho e sorgo, em parceria com diversas entidades de ensino no país, estruturou uma linha de pesquisa voltada ao aproveitamento desse cereal para a alimentação humana e posterior difusão sobre os benefícios do sorgo para os seres humanos (EMBRAPA, 2009).

Devido não apresentar uma proteção natural para as sementes, a planta de sorgo pode produzir substâncias com a finalidade de defesa química contra pássaros, patógenos e outros competidores. Essas substâncias, denominadas compostos fenólicos, são um grupo de antioxidantes considerados como extranutricionais presentes em pequenas quantidades no alimento (KRIS-ETHERTON et al, 2002). Nos vegetais, podem ser divididos em flavonoides ou não-flavonoides e geralmente são responsáveis 
por apresentarem pigmentações variadas possibilitando também papel importante para a atração de polinizadores (SANTOS, 2007).

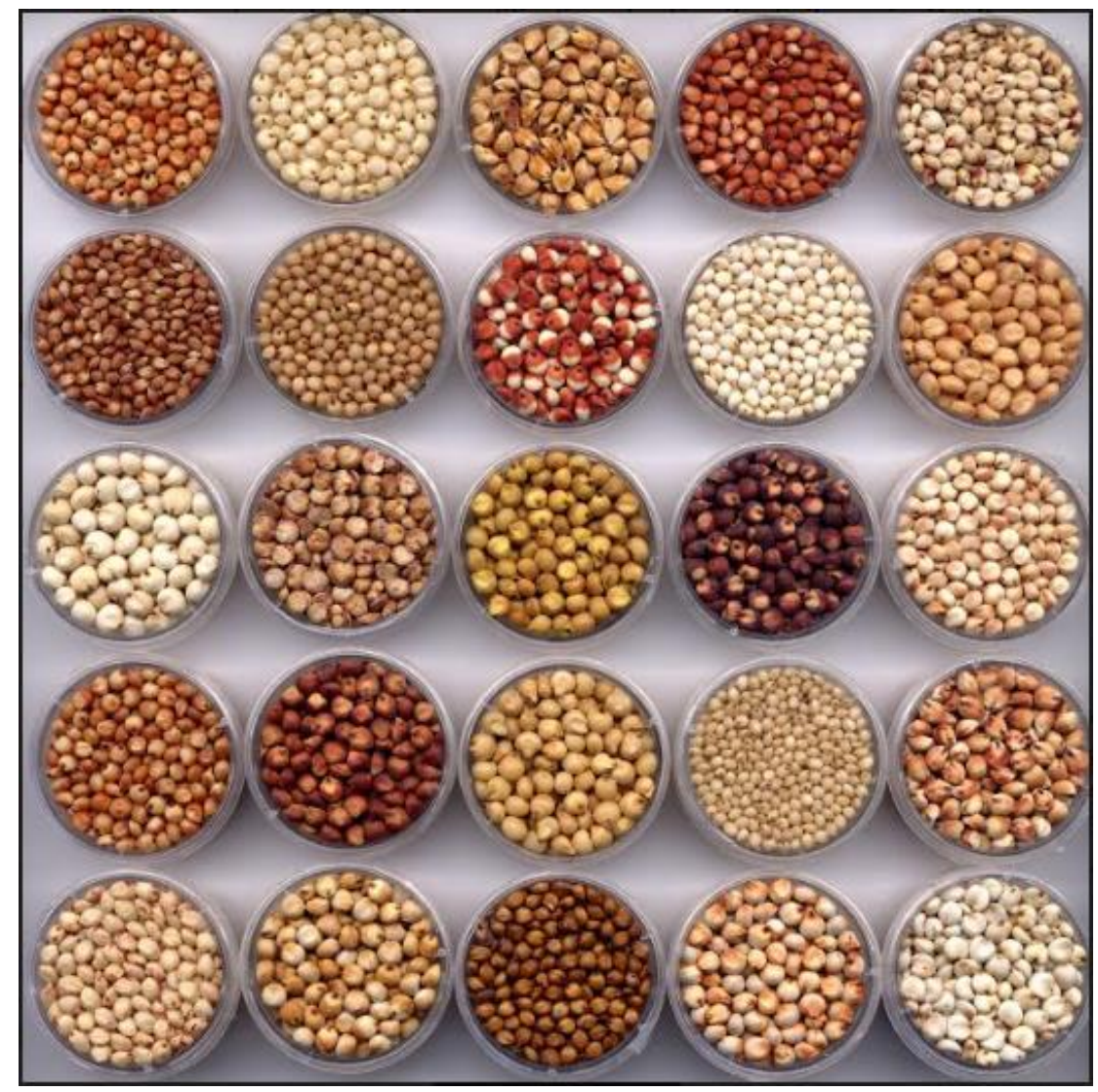

Figura 4: Variedades de sorgo com distintas colorações. Fonte: DE ALENCAR FIGUEIREDO L. F, 2016

Os antioxidantes são compostos bioativos que podem promover benefícios à saúde e reduzir o risco de desenvolvimento de doenças devido a sua capacidade de neutralizar os radicas livres. Esses radicais, constituídos de moléculas ou átomos quimicamente muito reativos, são responsáveis por induzir a oxidação de lipídios de membrana, proteínas e carboidratos prejudicando o correto funcionamento do organismo. O acúmulo de seus efeitos em longo prazo estão relacionados ao aparecimento de doenças crônicas, principalmente associadas ao envelhecimento, 
destacando-se câncer, aterosclerose e doenças inflamatórias (HARBONNE e WILLIANS, 2000; LIU, 2003; SEIFRIED et al, 2007).

Os três maiores grupos de fenólicos relacionados à dieta são os flavonoides, os ácidos fenólicos e os polifenóis (taninos). Com destaque para o terceiro grupo, algumas variedades de sorgo podem apresentar quantidades significativas de taninos em sua constituição (NYACHOTI et al, 1997; Dykes, 2006). Esses lhe proporcionam resistência, no entanto, são adstringentes e podem acarretar problemas de digestibilidade do grão.

Os taninos podem ser classificados em hidrolisáveis e condensados, sendo os condensados, também conhecidos como proantocianidinas, mais facilmente encontrados no grão de sorgo (EMBRAPA, 2009). Por estar relacionado com a pigmentação do grão, podemos encontrar genótipos com coloração variando do branco ao marrom, de acordo com a intensidade desses compostos (Dykes, 2006).

Outras características importantes do grão de sorgo são em relação aos teores de amido resistente e fibras alimentares. As fibras possuem papel ímpar no combate de comorbidades como o Diabetes tipo 2 atuando como redutoras no índice glicêmico, nos níveis de LDL e de triglicerídeos plasmáticos de preparações como as da panificação (QUEIROZ, 2009).

Com a presença de tantos fatores benéficos na constituição de alguns genótipos de sorgo, surge a necessidade de se investigar genótipos mais indicados e com melhor aptidão nutricional para o desenvolvimento de produtos alimentícios, aliado à necessidade de novos insumos para a produção de alimentos voltados ao público crescente com aversões ao glúten. Desse modo, o presente estudo visa a caracterizar física, química e nutricionalmente cinco diferentes genótipos de sorgo, principalmente 
quanto a seus teores de amido resistente e antioxidantes, assim como avaliar o efeito do processamento nas qualidades nutricionais de pães sem glúten. 


\section{OBJETIVOS}

\subsection{Objetivo Geral}

Caracterizar física, química e nutricionalmente cinco diferentes genótipos de sorgo, principalmente quanto a seus teores de amido resistente e antioxidantes, assim como avaliar o efeito do processamento nas qualidades nutricionais de pães sem glúten.

\subsection{Objetivos Específicos}

Elaborar farinhas dos diferentes genótipos de sorgo estudados (1167048 e BR 305 pericarpo marrom com taninos, BRS 330 e BRS 332 - pericarpo bronze sem taninos, CMSXS 180 - pericarpo branco sem taninos);

Caracterizar os aspectos químicos (umidade, cinzas, proteína bruta, lipídeos, fibras solúvel e insolúvel, amido resistente e amido solúvel, teor de amilose, fenólicos totais, taninos totais e atividade antioxiddante por DPPH - $\mathrm{IC}_{50}$ e FRAP) das farinhas à base de sorgo;

Confeccionar pães isentos de glúten à base de sorgo;

Caracterizar os aspectos químicos (amido resistente e amido solúvel, teor de amilose, fenólicos totais, taninos totais e atividade antioxiddante por DPPH - $\mathrm{IC}_{50} \mathrm{e}$ FRAP) das formulações de pães a base de sorgo;

Avaliar o impacto do processo de panificação nos compostos bioativos e na atividade antioxidante das preparações. 


\section{MATERIAIS E MÉTODOS}

O estudo de caráter experimental composto de duas etapas:

1) Análise dos grãos de cinco genótipos de sorgo, elaboração das suas farinhas e análises físicas e químicas, realizadas nos Laboratórios de Microbiologia do Departamento de Botânica (BOT) da Universidade de Brasília (UnB), Laboratório de Ciência e Tecnologia de Alimentos da Embrapa Cerrados em Planaltina - DF e no Laboratório de Ciência e Tecnologia de Alimentos da Universidade Católica de Brasília (UCB) em Taguatinga - DF.

2) Elaboração de cinco formulações de pães sem glúten e análises de teor de compostos fenólicos, taninos, atividade antioxidante in vitro, amilose, amido resistente das farinhas e dos pães, realizadas no laboratório de Técnica Dietética do Curso de Nutrição da Faculdade de Saúde (FS) da UnB, no Laboratório de Análise de Alimentos do Núcleo de Nutrição da UnB e no Laboratório de Tecnologia de Alimentos da Universidade Católica de Brasília (UCB) em Taguatinga - DF.

\subsection{Elaboração e caracterização das farinhas de sorgo}

Para a elaboração das farinhas foram utilizados cinco genótipos de sorgo (1167048 e BR 305 - pericarpo marrom com taninos, BRS 330 e BRS 332 - pericarpo bronze sem taninos, CMSXS 180 - pericarpo branco sem taninos), de diferentes composições nutricionais, produzidos na Embrapa Milho e Sorgo de Sete Lagoas - MG.

Os grãos foram produzidos seguindo as recomendações adequadas de plantio da cultura do sorgo. Antes do plantio a área foi dessecada com aplicação de Glyphosate WG 2 kg/ha. Na semeadura foi feita adubação de $350 \mathrm{~kg}$ de adubo 8-28-16 (NPK) e 
adubação de cobertura com $150 \mathrm{~kg} / \mathrm{ha}$ de Ureia. Para controle de plantas daninhas pósplantio foi aplicado Atrazine na concentração de 3,5 L/ha. A colheita destes parcelões foi feita manualmente. Todo o material foi plantado e colhido no ano de 2014, na área experimental da referida instituição. Após a colheita, foram avaliadas as características de vitreosidade e peso de 1000 grãos.

Tabela 1. Tipo de grão e características do pericarpo dos genótipos utilizados

\begin{tabular}{lcr}
\hline \multicolumn{1}{c}{ Genótipo } & Pericarpo & Tipo \\
\hline Comercial & Branco sem tanino & Híbrido \\
BRS 332 & Bronze sem tanino & Híbrido \\
BR 305 & Marrom com tanino & Híbrido \\
BRS 330 & Bronze sem tanino & Híbrido \\
1167048 & Marrom com tanino & Híbrido \\
CMSXS 180 & Branco sem tanino & Linhagem \\
\hline
\end{tabular}

Os grãos de sorgo previamente selecionados foram triturados em um moinho da marca HAWOS, modelo Muhle 1. Após esse procedimento, foram realizadas análises químicas para determinação da composição centesimal, fenólicos totais, taninos totais, amido resistente, teor de amilose e atividade antioxidante por DPPH e FRAP nas farinhas.

\subsection{Elaboração dos Pães}

Para seleção da receita padrão dos pães com as distintas farinhas de sorgo, foram realizados testes no Laboratório de Técnica Dietética do Curso de Nutrição da Faculdade de Saúde (FS) da Universidade de Brasília (UnB). As receitas foram adaptadas para adequação dos ingredientes que obtivessem melhor resultado tecnológico em um produto de panificação sem glúten (PINELI et al, 2015). 
Posteriormente, foi elaborada com o auxílio do programa Dietbox ${ }^{\circledR}$, para o cálculo dos macronutrientes, a ficha técnica da preparação padrão (Apêndice I). A média do preço dos ingredientes foi levantado em estabelecimentos varejistas da região de Brasília em junho de 2016.

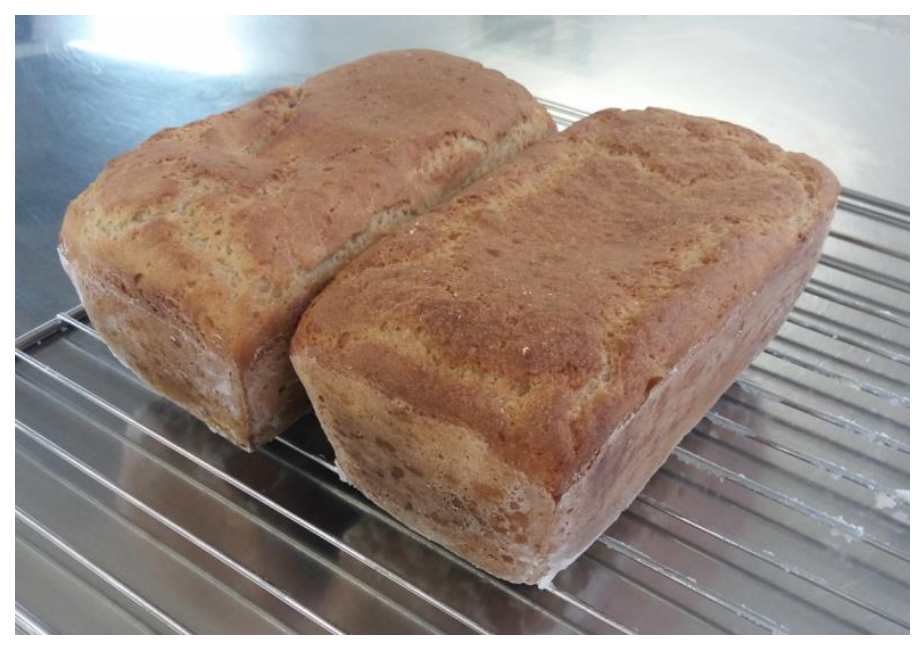

Figura 5: Teste de receita de pão sem glúten.

Uma vez determinada a receita padrão, foram elaborados seis pães com aproximadamente $500 \mathrm{~g}$ cada. Cada preparo divergiu apenas na farinha de sorgo utilizada, sendo cinco dos genótipos elencados para avaliação e uma da farinha comercial de sorgo branco marca Bob's Red Milll (EUA) como padrão. 
Tabela 2. Proporção dos ingredientes da receita padrão do pão de sorgo

\begin{tabular}{lr}
\hline \multicolumn{1}{c}{ Ingredientes } & Quantidade (\%) \\
\hline Farinha de sorgo & 61 \\
Fécula de batata & 28 \\
Polvilho doce & 11 \\
Gelatina em pó sem sabor & 1 \\
Goma xantanta & 1 \\
Açúcar mascavo & 8 \\
Sal & 2 \\
Óleo & 15 \\
Água morna & 91 \\
Ovo inteiro & 15 \\
Clara de ovo & 9 \\
Fermento biológico seco & 3 \\
Açúcar mascavo (para fermento) & 3 \\
Água (para fermento) & 36 \\
\hline
\end{tabular}

O preparo consistiu nas seguintes etapas: ativação do fermento biológico seco, mistura dos ingredientes secos, adição dos demais ingredientes, molde do preparo (formas) e cozimento em forno. Posteriormente todos os pães foram desenformados e esfriaram à temperatura ambiente para serem porcionados em cinco lotes. As amostras foram liofilizadas e armazenadas à temperatura de $-80^{\circ} \mathrm{C}$ até a realização das análises.

\subsection{Métodos analíticos}

A composição centesimal das farinhas foi determinada utilizando-se os métodos descritos a seguir.

\section{Análise de Vitreosidade}

A vitreosidade foi obtida por meio da determinação visual do escore das áreas de endospermas vítreo e farináceo, na secção transversal paralela ao gérmen do grão (Maxson, 1971). A unidade empregada para a vitreosidade dos grãos foi em porcentagem (\%) do grão. 
O escore 1 foi atribuído aos grãos de textura dura (endosperma vítreo), o 2 aos de textura médio dura, o 3 aos de textura média (metade do endosperma vítreo e metade farináceo), o 4 aos de textura médio macia, e o 5 aos de textura macia (endosperma farináceo).

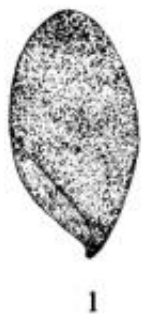

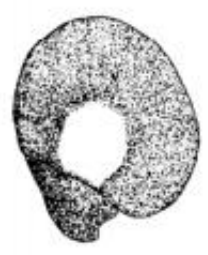

3

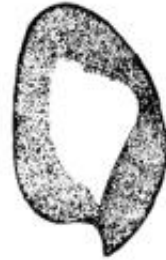

5

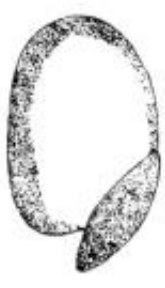

7

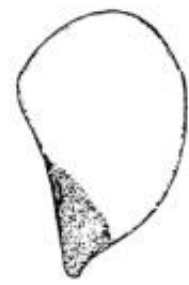

9

Fig. 6. Texture de l'endosperme

\section{Análise do Peso de 1000 Grãos}

Após a seleção dos grãos íntegros, foi realizada a homogeneização do lote e, posteriormente, foram separadas três repetições de 100 grãos, os quais foram pesados em uma balança digital obtendo-se a massa de 1000 grãos por meio da média das pesagens. Posteriormente multiplicou-se o resultado em dez para estimar o peso de 1000 grãos. A unidade utilizada foi em gramas (g).

\section{Análise de Umidade e Cinzas}

$\mathrm{O}$ teor de água (umidade) foi determinado pelo método da secagem a $105^{\circ} \mathrm{C}$ com circulação de ar, de acordo com metodologia da Association of Official Analytical Chemists (AOAC, 1997). As cinzas foram obtidas a partir do princípio da incineração à $500^{\circ} \mathrm{C}$ (AOAC, 1997). A unidade empregada das análises foi em g/100 g.

\section{Análise do Teor de Proteína Bruta}

O teor de proteína bruta foi determinado pelo método de Kjeldahl. Nesse método, determina-se o nitrogênio contido na matéria orgânica, incluindo o nitrogênio 
proteico propriamente dito e outros compostos nitrogenados não proteicos, como aminas, amidas, lecitinas, nitrilas e aminoácidos, mas o nitrogênio, em forma de nitrato e nitrito, não é determinado. Dessa forma o nitrogênio total foi determinado pelo método de Kjeldahl, segundo AOAC (1997), fator de correção de 6,25 e a unidade empregada $\mathrm{g} / 100 \mathrm{~g}$.

\section{Análise do teor de Extrato Etéreo}

O extrato etéreo ou lipídeos totais foram determinados pelo método de extração Soxhlet segundo AOAC (1997) e apresentado na unidade de g/100 g.

\section{Análise do Teor de Fibras Solúveis e Insolúveis}

Para determinação dos teores de fibras solúveis e insolúveis foi empregado o método enzimático que caracteriza quimicamente os carboidratos contidos na fibra após remoção dos carboidratos disponíveis (monossacarídeos, dissacarídeos e amido). A unidade final é dada em g/100 g (AOAC, 2005).

\section{Análise do Teor de Amido Resistente, Amido Solúvel e Amido Total}

A determinação do amido resistente foi realizada utilizando-se o kit da Megazyme, K-SRTAR 09/14, segundo a metodologia da AOAC, Method 2002.02 (McCLEARLY; MONAGHAN, 2002). O princípio do método consiste nas amostras incubadas com $\alpha$-amilase pancreática e amiloglicosidase (AMG) por dezesseis horas a $37^{\circ} \mathrm{C}$, em banho com agitação. Durante este tempo, o amido não resistente é solubilizado e hidrolisado em D-glicose pela ação das duas enzimas combinadas. A reação é finalizada com a adição de um mesmo volume de etanol e os grânulos de amido resistente são recuperados por centrifugação, lavados duas vezes com etanol (50\%), seguido de centrifugação. O líquido livre é removido pela decantação. O amido resistente no grânulo é dissolvido em $\mathrm{KOH} 2 \mathrm{M}$ através de agitação vigorosa em banho 
gelado com agitador magnético. A solução é neutralizada com tampão acetato e o amido é quantitativamente hidrolisado a glicose com a AMG. A quantidade de D-glicose é medida com o reagente glicose oxidase / peroxidase (GOPOD) e esta é a determinação do amido resistente contido na amostra. $\mathrm{O}$ amido não resistente (amido solubilizado) é determinado com os acúmulos de sobrenadantes e das lavagens ao ajustar o volume para 100 mL e por meio da medição do conteúdo de D-glicose com GOPOD.

\section{Análise do Teor de Amilose}

O teor de amisole / amilopectina foi determinado utilizando-se o kit K-AMYL 09/14 da Megazyme (Ireland) segundo método do dimetilsulfóxido (DMSO). As amostras tiveram seu teor de amilose determinado enzimaticamente e analisada usando o reagente glucose/peroxidase (GOPOD). O amido total foi determinado em uma alíquota separada em espectrofotômetro à 510nm.

Preparo de extrato para análises de compostos fenólicos, taninos e atividade antioxidante por FRAP e DPPH

O preparo dos extratos seguiu o protocolo adaptado do método desenvolvido por Singleton e Rossi (1965). Pesou-se 0,5g de amostra (previamente liofilizada e triturada) de cada farinha e pão em triplicata em um tubo Falcon de 15 mL. Adicionou-se, então, $10 \mathrm{~mL}$ de metanol $70 \%$ acidificado com $1 \% \mathrm{HCl}$ e agitado por duas horas em mesa agitadora. Após agitação, as amostras foram deixadas em repouso por doze horas.

Passadas as doze horas, as amostras foram centrifugadas a $4000 \mathrm{rpm}$ por dez minutos e o sobrenadante recolhido em Falcon de 50mL.

Foram realizados quatro extratos, sendo dois de metanol $70 \%$ acidificado com $1 \%$ HCL (uma adição de $10 \mathrm{~mL}$ e outra de $5 \mathrm{~mL}$ ) e duas extrações com acetona $70 \%$ (uma adição de $10 \mathrm{~mL}$ e outra de $5 \mathrm{~mL}$ ). $\mathrm{O}$ volume coletado foi então avolumado com 
água destilada em balão volumétrico de $50 \mathrm{~mL}$ e filtrado com lã de vidro. O acondicionamento das amostras foi em vidro âmbar de $50 \mathrm{~mL}$. Os extratos foram mantidos sob congelamento até o momento das análises.

O preparo dos extratos e as análises foram realizados ao abrigo da luz.

\section{Análise de Compostos Fenólicos Totais}

O teor de compostos fenólicos totais foi realizado pelo método Folin-Ciocalteau de acordo com o descrito por Singleton e Rossi (1965). A amostra foi diluída de acordo com testes prévios, nos quais massas que apresentem maior quantidade de fenólicos têm maior diluição, enquanto outras foram realizadas sem diluição. Foi pipetado $1 \mathrm{~mL}$ de cada extrato em triplicata, adicionado de $1 \mathrm{~mL}$ da solução Folin. Após um minuto, foram adicionados $2 \mathrm{~mL}$ de carbonato de sódio $20 \%$ e $2 \mathrm{~mL}$ de água destilada. Após 30 minutos, a leitura da absorbância foi realizada a $700 \mathrm{~nm}$.

\section{Análise de Taninos Totais}

A análise de Taninos foi realizada de acordo com o método DMAC (BRANDWILLIANS et al., 1995). No qual foram pipetados $70 \mu \mathrm{L}$ de cada extrato e adicionados $210 \mu \mathrm{L}$ do reagente DMAC na microplaca de poliestireno com 96 cavidades.

Após pipetada, a microplaca foi instalada no espectrofotômetro de placas e, após 25 minutos, a leitura foi realizada a $630 \mathrm{~nm}$.

\section{Atividade Antioxidante por DPPH}

A atividade antioxidante foi determinada utilizando o método (DPPH) descrito por BRAND-WILLIAMS et al., (1995). Este método se baseia na redução da absorbância medida a $515 \mathrm{~nm}$ do radical DPPH por antioxidantes. Adicionou-se $0,1 \mathrm{~mL}$ de amostra, depois 3,9 mL da solução DPPH e realizou-se a leitura da absorbância a 515 $\mathrm{nm}$. 


\section{Atividade Antioxidante por FRAP}

O método utilizado para a determinação da atividade antioxidante por FRAP foi a de PULIDO et al. (2000), no qual transfere-se uma alíquota de $90 \mu \mathrm{L}$ de cada extrato para tubos de ensaio em três diluições consecutivas. Neste estudo foram utilizadas as concentrações de amostra de 100\%, 75\%, 50\%, $25 \%$ e 12,5\%, de acordo com testes prévios. Acrescentou-se então $270 \mu \mathrm{L}$ de água destilada e 2,7 mL de reagente FRAP. Os tubos de ensaio foram então colocados em banho maria a $37^{\circ} \mathrm{C}$ por trinta minutos. Passado o período, realizou-se a leitura a $595 \mathrm{~nm}$.

\section{Delineamento Experimental e Análise Estatística}

As análises foram esquematizadas em delineamento inteiramente casualizado, com 6 tipos de farinhas de sorgo (cinco genótipos mais uma comercial) e três repetições (lotes). A unidade experimental das farinhas e pães elaborados foi composta, respectivamente, por uma embalagem de farinha com $300 \mathrm{~g}$ e três unidades de pão de forma de aproximadamente $500 \mathrm{~g}$ de cada genótipo, suficientes para as análises químicas em triplicata. Os dados foram analisados por ANOVA $(p<0,05)$ e no caso de diferença significativa o teste de comparação de médias de Tukey foi aplicado $(p<0,05)$. Posteriormente nos dados foi aplicada regressão multivariada dos Mínimos Quadrados Parciais (PLS - Partial Least Square). Todas as análises estatísticas foram realizadas pelo programa XLSTAT (ADDINSOFT, França). 


\section{RESULTADOS E DISCUSSÃO}

Dada a grande variabilidade genética do sorgo, espera-se que farinhas e grãos de diferentes genótipos apresentem diferenças que impactem nas características nutricionais, tecnológicas e sensoriais dos produtos derivados, como os de panificação. Este estudo focou nos impactos nutricionais associados à variabilidade do sorgo.

A Tabela 3 mostra a característica visual e dados de vitreosidade e peso dos grãos dos genótipos utilizados no estudo. Do lado esquerdo está apresentada a imagem frontal e posterior dos grãos de sorgo. Nessa parte observa-se a pigmentação geral do grão. Como descrito anteriormente, das cinco amostras utilizadas no estudo duas possuem pericarpo com pigmentação marrom escuro (BR 305 e 116748), bronze (BRS 330 e BRS 332) e uma branca (CMSXS 180). Na segunda coluna tem-se o corte transversal de forma a apresentar o interior do grão. A fração esbranquiçada no centro e a fração pigmentada nas extremidades representam a porção farinácea e a porção vítrea do grão respectivamente. 
Tabela 3. Característica visual e valores de vitreosidade e peso de 100 grãos dos grãos selecionados para o estudo.

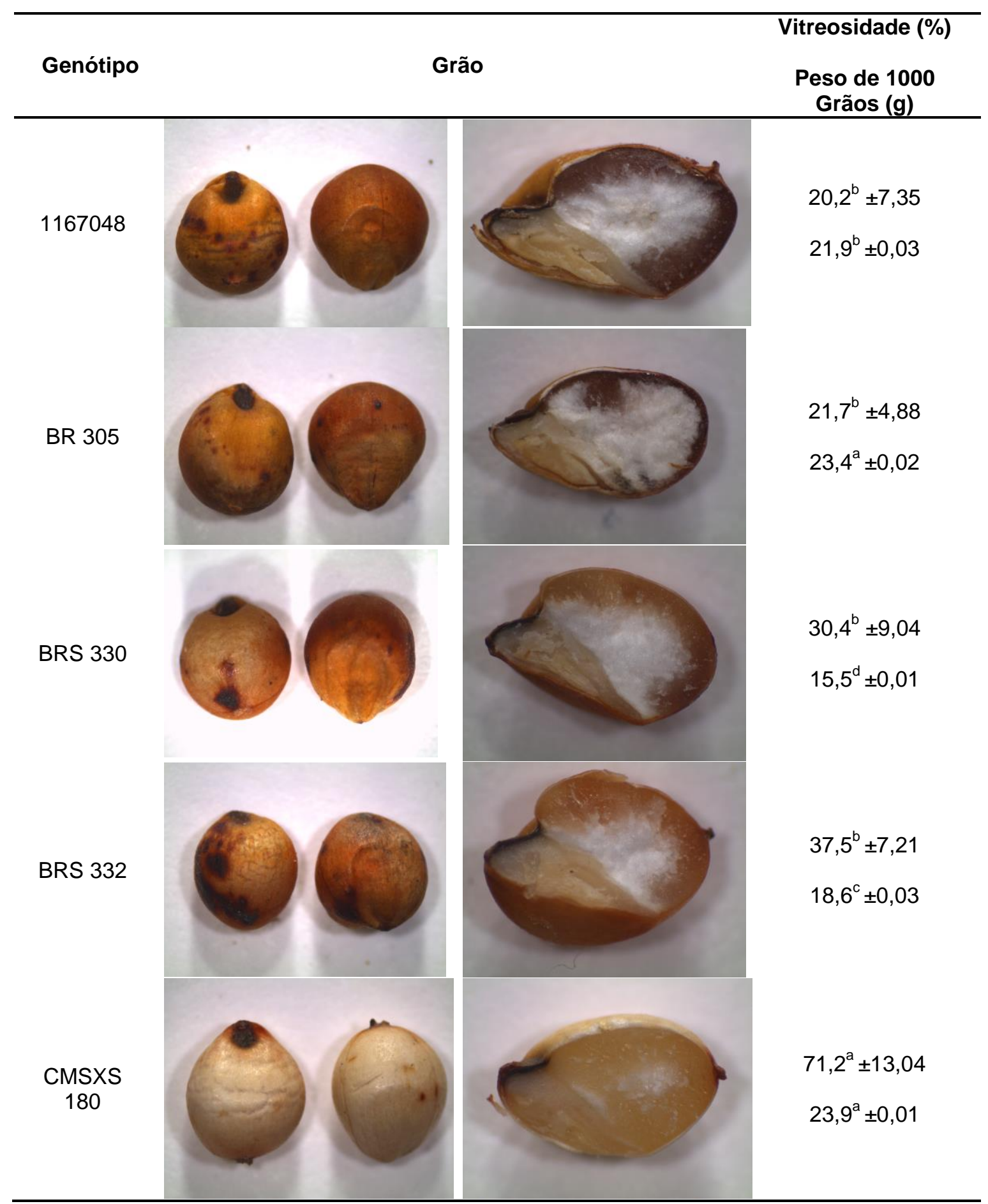

Valores constituem médias \pm desvios padrão $(n=3)$. Em uma mesma coluna, médias com letras iguais não apresentam diferenças significativas pelo teste de Tukey $(\mathrm{p} \leq 0,05)$. 
Com base na distribuição dos grânulos de amido e da matriz de proteínas o endosperma do grão de sorgo pode ser classificado como farináceo ou vítreo. De acordo com a Tabela 3, o genótipo CMSXS 180 apresenta endosperma com maior constituição vítrea. Isso pode ser observado claramente na imagem do grão seccionado, onde observamos uma menor porção esbranquiçada no interior. A vitreosidade mede a proporção de endosperma vítreo no grão e quanto maior essa proporção, mais duro será o grão (CORREA et al., 2002). Antunes et al. (2008) observou a alta correlação $(0,87)$ entre a vitreosidade e densidade do grão, quanto maior a vitreosidade, maior o grau de dureza do grão e menor seu grau farináceo. Segundo Lima et al. (2001), grãos extremamente vítreos como o genótipo CMSXS 180 geralmente estão associados a maior dureza e consecutivamente menor digestibilidade. Esse fator impacta diretamente na qualidade durante a produção da farinha. Os demais genótipos apresentaram percentual de vitreosidade semelhantes entre si. O peso de 1000 grãos variou de 23,9 g para o genótipo CMSX180 e 15,5 g para o BRS 330. As amostras BR 305 e CMSXS 180 apresentaram maior massa dos grãos indicando uma maior densidade quando comparado aos demais. Dessa forma, observa-se que a relação entre essas duas variáveis (vitreosidade e densidade) foi semelhante o apresentado por esses autores. O genótipo CMSXS 180 foi o que apresentou estatisticamente maior vitreosidade $(71,2 \%)$ que os demais analisados assim como maior massa $(23,9 \mathrm{~g} / 100 \mathrm{~g})$. Estudo realizado por Antunes (2008) encontrou valor médio de 21,38g/1000 grãos, dentro do intervalo obtido para este estudo.

Para a composição das farinhas (Tabela 4), observou-se menor teor de água (12,5 g/100g) para o híbrido 1167048 de pericarpo marrom com tanino, e nenhuma 
diferença entre os demais genótipos, variando de $13,7 \mathrm{~g} / 100 \mathrm{~g}$ a $14,7 \mathrm{~g} / 100 \mathrm{~g}$. A farinha produzida a partir do genótipo 1167048 , por apresentar menor concentração de umidade em sua composição, pode resultar na menor proliferação microbiológica, visto que a água é um dos fatores primordiais para o desenvolvimento de organismos patogênicos (JUNIOR, et al., 2013).

O híbrido 1167048 e a linhagem CMSXS 180 foram os que apresentaram uma proporção estatisticamente inferior de proteínas. Um estudo realizado por Queiroz (2015) avaliou a composição nutricional de 100 genótipos de sorgo, diferentes dos analisados no presente estudo, apresentou teores de proteínas com variação de 8,6 a 18,9 g/100g. Outro estudo, Galle (2012), mostrou que o teor proteico do sorgo pode variar em média de 7,8 a 12,9g/100g. Dessa forma, os valores encontrados nesse estudo estão dentro do intervalo relatado.

A farinha do cultivar BR 305 foi a que apresentou maior teor de fibras insolúveis, cerca de $63 \%$ maior do que o teor da farinha de sorgo comercial (controle), que possui a menor quantidade deste tipo de fibra. Ao se comparar com a farinha de trigo integral, com média de $38 \mathrm{~g}$ de fibras insolúveis e $4 \mathrm{~g}$ de fibras solúveis em $100 \mathrm{~g}$ de farinha, os valores encontrados para o sorgo são $50 \%$ inferiores. No entanto, quando comparados a produtos com maiores teores de fibras como a aveia $(9,5 \mathrm{~g}$ de fibras insolúveis) e largamente utilizada na produção alimentícia, o sorgo apresenta maiores quantidades de fibras insolúveis (FIBRAS, 1999; ABOUBACAR et al., 2006). As fibras possuem papel ímpar no organismo humano, são responsáveis por aumentar o volume do conteúdo gástrico retardando seu esvaziamento e proporcionando uma saciedade prolongada. Além disso, atuam no controle insulinêmico e estimulam a mobilidade intestinal (GIUNTINI, 2003). Para fibras solúveis, os maiores teores foram encontrados 
para a farinha comercial e para a cultivar marrom com taninos BRS 305 que, em média foram 7,7 vezes maiores que o menor teor encontrado para a cultivar bronze sem tanino BRS 330. Os demais genótipos apresentaram teores intermediários de fibras solúveis. Uma maior quantidade de hidrocoloides como as fibras solúveis é benéfica na produção de pães, pois as fibras presentes na formulação podem contribuir para a retenção de umidade dos pães durante o assamento, contribuindo positivamente para o volume das preparações. Moraes et al., (2015) ao analisar a composição da farinha de sorgo, elaborada com um genótipo de pericarpo marrom, encontrou quantidade de fibras totais de aproximadamente $11,53 \mathrm{~g} / 100 \mathrm{~g}$, inferior aos valores encontrados nesse estudo.

A amostra CMSXS 180 de sorgo de pericarpo branco apresentou maior quantidade de amido solúvel do que as demais. Trata-se de uma farinha elaborada com sorgo branco sem taninos. No outro extremo, o genótipo BR 305, pericarpo marrom com tanino, apresentou quantidade muito inferior de amido solúvel que o esperado, o que pode ser resultado de alguma interferência de outros compostos, como o próprio tanino, ao se complexar com o amido. De acordo com Sullins \& Rooney (1975), grãos com uma maior porção de endosperma vítreo apresentam teores elevados de proteínas e consecutivamente diminuição da porção de amido disponível para a degradação enzimática. Todavia, a linhagem CMSXS 180 apresentou maior teor de amido e maior teor de amido solúvel, sugerindo que outros fatores não avaliados pelos autores podem estar mais associados à vitreosidade do endosperma.

O genótipo BR 305 também apresentou elevado valor de amido resistente em sua constituição $(4,34 \mathrm{~g} / 100 \mathrm{~g})$ quando comparado aos demais genótipos analisados. Teixeira (2016) ao analisar o teor de amido resistente em 49 genótipos de sorgo encontrou uma variação expressiva com valores entre 0,31 e 65,65 g/100g por amostra. 
A linhagem 116748 apresentou a maior concentração de amilose (19,6 g/100g). Farinhas provenientes de trigo e milho, em geral, possuem teores mais elevados de amilose (26 a $30 \mathrm{~g} / 100 \mathrm{~g})$. Essa estrutura influencia no poder geleificante do amido e na viscosidade das preparações, devido sua elevada solubilidade em água, podendo contribuir na retenção dos gases oriundos da fermentação (DAMODARAN; PARKIN, FENNEMA, 2010). Dessa forma, espera-se que essa linhagem apresente um melhor desenvolvimento da massa quando comparada as demais.

O teor de compostos fenólicos totais do cultivar BR 305 foi $81 \%$ mais elevado do que o híbrido experimental marrom com taninos 1167048. Não houve diferença entre os genótipos de pericarpos bronze e brancos, incluindo a farinha comercial, para esta variável, cujos teores foram em média 7,7 vezes inferiores à farinha de 1167048. Ao contrário dos cereais convencionais como trigo e arroz, o sorgo tem se apresentado como fonte de antioxidantes em função da presença de compostos fenólicos em sua composição (GÜLÇIN, 2010; AWIKA, 2009). Do mesmo modo, os genótipos BR 305 e 1167048 apresentaram as maiores concentrações de taninos com 609,9 e 350,5mg de proantocianidina/100g, respectivamente. Na literatura são encontrados estudos utilizando a metodologia de catequinas para quantificar o teor de taninos condensáveis no sorgo. Moraes et al. (2015) apresentou teor médio de 0,54mg de CatE/g ${ }^{-1}$.

Ao se analisar a atividade antioxidante pelo método DPPH (BRANDWILLIANS et al., 1995) o resultado foi expresso em IC $_{50}$, concentração necessária de antioxidante para reduzir em $50 \%$ o radical DPPH, de modo que, quanto menor o $\mathrm{IC}_{50}$, maior é a atividade antioxidante da farinha de sorgo utilizada. 
Tabela 4. Valores de composição, compostos bioativos e atividade antioxidante das farinhas elaboradas em comparação com a comercial

\begin{tabular}{|c|c|c|c|c|c|c|c|c|c|c|c|c|c|}
\hline \multirow[b]{2}{*}{ Genótipo } & \multirow{2}{*}{$\begin{array}{l}\text { Umidade } \\
\text { ( } \mathrm{g} / 100 \mathrm{~g})\end{array}$} & \multirow{2}{*}{$\begin{array}{l}\text { Cinzas } \\
(\mathrm{g} / 100 \mathrm{~g})\end{array}$} & \multirow{2}{*}{$\begin{array}{l}\text { Proteínas } \\
\text { (g/100g) }\end{array}$} & \multirow{2}{*}{$\begin{array}{l}\text { Lipídios } \\
\text { (g/100g) }\end{array}$} & \multicolumn{2}{|c|}{ Fibras $(\mathrm{g} / 100 \mathrm{~g})$} & \multicolumn{2}{|c|}{ Amido $(\mathrm{g} / 100 \mathrm{~g})$} & \multirow{2}{*}{$\begin{array}{l}\text { Amilose } \\
(\%)\end{array}$} & \multirow{2}{*}{$\begin{array}{c}\text { Fenólicos } \\
\text { Totais } \\
\text { (mg/100g) }\end{array}$} & \multirow{2}{*}{$\begin{array}{l}\text { Taninos } \\
\text { Totais (mg } \\
\text { de } \\
\text { proantociani } \\
\text { dina/100g) }\end{array}$} & \multirow{2}{*}{$\begin{array}{c}\text { DPPH EC50 } \\
(\mu \mathrm{g} \text { Teq } / \mathrm{g})\end{array}$} & \multirow{2}{*}{$\begin{array}{c}\operatorname{FRAP}(\mu \mathrm{M} \\
\text { trolox/g) }\end{array}$} \\
\hline & & & & & Insolúveis & Solúveis & $\begin{array}{c}\text { Resistent } \\
\mathrm{e}\end{array}$ & Solúvel & & & & & \\
\hline Comercial & $\begin{array}{l}14,3^{A} \\
\pm 0,14\end{array}$ & $\begin{array}{l}1,38^{A B} \\
\pm 0,17\end{array}$ & $\begin{array}{l}9,31^{A} \\
\pm 0,05\end{array}$ & $\begin{array}{l}2,75^{C} \\
\pm 0,17\end{array}$ & $\begin{array}{l}10,50^{\circ} \\
\pm 0,03\end{array}$ & $\begin{array}{l}2,24^{A} \\
\pm 0,26\end{array}$ & $\begin{array}{l}0,01^{\mathrm{E}} \\
\pm 0,01\end{array}$ & $\begin{array}{l}60,4^{\mathrm{B}} \\
\pm 0,22\end{array}$ & $\begin{array}{l}9,89^{\mathrm{C}} \\
\pm 0,49\end{array}$ & $\begin{array}{c}134^{C} \\
\pm 4,20\end{array}$ & $10,6^{\mathrm{C}} \pm 1,26$ & $18,6^{A} \pm 3,49$ & $35,1^{\mathrm{D}} \pm 7,50$ \\
\hline BRS 332 & $\begin{array}{l}14,5^{\mathrm{A}} \\
\pm 0,05\end{array}$ & $\begin{array}{l}1,37^{A B} \\
\pm 0,13\end{array}$ & $\begin{array}{l}9,52^{\mathrm{A}} \\
\pm 0,17\end{array}$ & $\begin{array}{l}3,39^{\mathrm{B}} \\
\pm 0,05\end{array}$ & $\begin{array}{l}12,30^{\mathrm{C}} \\
\pm 0,23\end{array}$ & $\begin{array}{l}1,16^{\mathrm{B}} \\
\pm 0,00\end{array}$ & $\begin{array}{l}0,67^{\mathrm{C}} \\
\pm 0,03\end{array}$ & $\begin{array}{l}58,1^{\mathrm{C}} \\
\pm 0,86\end{array}$ & $\begin{array}{l}16,6^{b} \\
\pm 0,11\end{array}$ & $\begin{array}{l}218^{\mathrm{C}} \\
\pm 2,80\end{array}$ & $21,4^{\mathrm{C}} \pm 0,00$ & $20,3^{A} \pm 3,96$ & $113,6^{\mathrm{C}} \pm 16,7$ \\
\hline BR 305 & $\begin{array}{l}14,2^{\mathrm{A}} \\
\pm 0,00\end{array}$ & $\begin{array}{l}1,53^{\mathrm{A}} \\
\pm 0,03\end{array}$ & $\begin{array}{l}9,35^{\AA} \\
\pm 0,06\end{array}$ & $\begin{array}{l}2,14^{\mathrm{D}} \\
\pm 0,16\end{array}$ & $\begin{array}{l}17,10^{\mathrm{A}} \\
\pm 0,54\end{array}$ & $\begin{array}{l}2,71^{\mathrm{A}} \\
\pm 0,42\end{array}$ & $\begin{array}{l}3,80^{\AA} \\
\pm 0,01\end{array}$ & $\begin{array}{l}17,6^{\mathrm{D}} \\
\pm 0,17\end{array}$ & $\begin{array}{l}14,6^{\mathrm{b}} \\
\pm 0,43\end{array}$ & $\begin{array}{l}1493^{\mathrm{A}} \\
\pm 11,7\end{array}$ & $609,9^{A} \pm 1,27$ & $4,40^{\mathrm{B}} \pm 0,18$ & $802,0^{A} \pm 12,3$ \\
\hline BRS 330 & $\begin{array}{l}13,7^{\mathrm{A}} \\
\pm 0,00\end{array}$ & $\begin{array}{l}1,21^{\mathrm{BC}} \\
\pm 0,05\end{array}$ & $\begin{array}{l}9,54^{\mathrm{A}} \\
\pm 0,16\end{array}$ & $\begin{array}{l}3,11^{\mathrm{BC}} \\
\pm 0,17\end{array}$ & $\begin{array}{l}14,10^{\mathrm{B}} \\
\pm 0,01\end{array}$ & $\begin{array}{l}0,32^{\mathrm{C}} \\
\pm 0,03\end{array}$ & $\begin{array}{l}0,89^{\mathrm{B}} \\
\pm 0,06\end{array}$ & $\begin{array}{l}60,3^{\mathrm{B}} \\
\pm 0,11\end{array}$ & $\begin{array}{l}11,1^{\mathrm{c}} \\
\pm 0,29\end{array}$ & $239^{\mathrm{C}} \pm 14,9$ & $20,7^{\mathrm{C}} \pm 1,26$ & $21,8^{\mathrm{A}} \pm 2,87$ & $121,7^{\mathrm{C}} \pm 11,3$ \\
\hline 1167048 & $\begin{array}{l}12,5^{\mathrm{B}} \\
\pm 0,08\end{array}$ & $\begin{array}{l}1,31^{\mathrm{AB}} \\
\pm 0,08\end{array}$ & $\begin{array}{l}8,59^{\mathrm{B}} \\
\pm 0,20\end{array}$ & $\begin{array}{l}3,36^{\mathrm{B}} \\
\pm 0,19\end{array}$ & $\begin{array}{l}14,20^{\mathrm{B}} \\
\pm 0,31\end{array}$ & $\begin{array}{l}1,56^{\mathrm{B}} \\
\pm 0,15\end{array}$ & $\begin{array}{l}0,35^{\mathrm{D}} \\
\pm 0,03\end{array}$ & $\begin{array}{l}59,5^{\mathrm{BC}} \\
\pm 1,15\end{array}$ & $\begin{array}{l}10,3^{c} \\
\pm 0,25\end{array}$ & $\begin{array}{c}824^{\mathrm{B}} \\
\pm 17,0\end{array}$ & $350,5^{\mathrm{B}} \pm 10,2$ & $6,05^{\mathrm{B}} \pm 0,11$ & $400,1^{B} \pm 45,7$ \\
\hline $\begin{array}{c}\text { CMSXS18 } \\
0\end{array}$ & $\begin{array}{l}14,7^{\mathrm{A}} \\
\pm 0,18\end{array}$ & $\begin{array}{l}1,02^{\mathrm{C}} \\
\pm 0,01\end{array}$ & $\begin{array}{l}8,66^{\mathrm{B}} \\
\pm 0,11\end{array}$ & $\begin{array}{l}4,66^{A} \\
\pm 0,12\end{array}$ & $\begin{array}{l}12,70^{\mathrm{C}} \\
\pm 0,07\end{array}$ & $\begin{array}{l}1,21^{\mathrm{B}} \\
\pm 0,12\end{array}$ & $\begin{array}{l}0,00^{\mathrm{E}} \\
\pm 0,00\end{array}$ & $\begin{array}{l}65,9^{A} \\
\pm 0,10\end{array}$ & $\begin{array}{l}19,6^{\mathbf{a}} \\
\pm 0,08\end{array}$ & $\begin{array}{r}173^{\mathrm{C}} \\
\pm 4,80\end{array}$ & $16,0^{\mathrm{C}} \pm 0,93$ & $17,6^{A} \pm 0,82$ & $62,6^{\mathrm{D}} \pm 5,0$ \\
\hline
\end{tabular}

Comercial White Tanin Free - WTF, BRS 332 Bronze Tanin Free - BZTF, BR 305 Brown Tanin - BT, BRS 330 Bronze Tanin Free - BZTF, 1167048 Brown Tanin - BT,

CMSXS 180 White Tanin Free - WTF. Valores constituem médias \pm desvios padrão $(\mathrm{n}=3)$. Em uma mesma coluna, médias com letras iguais não apresentam diferenças significativas pelo teste de Tukey $(\mathrm{p} \leq 0,05)$. 
Dada a complexidade em se analisar a atividade antioxidante dos materiais orgnânicos há a necessidade de se comparar, no mínimo, dois métodos distintos (CHOI, et al., 2002). Desse modo, os métodos utilizados nesse estudo foram o de DPPH (IC 50 e FRAP. As amostras BR 305 e 1167048 se destacaram frente às demais farinhas com

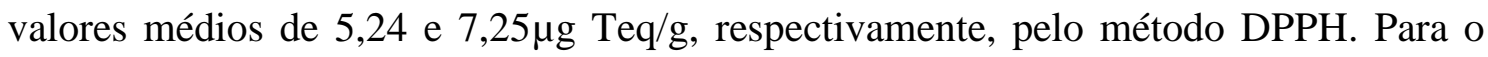
método FRAP, observou-se maior atividade da farinha elaborada com o genótipo BR $305(802,0 \mu \mathrm{M}$ Trolox/g). Esses resultados se devem, provavelmente, ao maior teor de taninos, compostos altamente antioxidantes, nesses dois genótipos. Um estudo realizado por Moraes et al. (2005) avaliou a atividade antioxidante por FRAP de três farinhas distintas de farinha de sorgo de pericarpo marrom (genótipo SC 21) provenientes do grão integral $\left(90,74 \mu \mathrm{M}\right.$ Trolox $\left./ \mathrm{g}^{-1}\right)$, polido $\left(10,62 \mu \mathrm{M}\right.$ Trolox $\left./ \mathrm{g}^{-1}\right)$ ou do farelo $(307,4$ $\mu \mathrm{M}$ Trolox $/ \mathrm{g}^{-1}$ ). Dessa forma, a atividade antioxidante obtida, principalmente do híbrido BR 305, foi semelhante ao apresentado por Moraes et al. (2005) para o grão integral. Pressupõe-se que esses dois genótipos são semelhantes quanto a sua atividade antioxidante.

\section{Efeito do processamento}

$\mathrm{Na}$ Tabela 5 são apresentados os dados determinados e estimados de composição, compostos bioativos e atividade antioxidante dos pães de sorgo. Foi utilizada a Tabela de Composição dos Alimentos (TACO), disponibilizada pela Universidade de Campinas (Unicamp), para a estimativa da composição dos pães. Os demais valores estimados foram calculados extrapolando-se os dados de composição das farinhas elaboradas com os diferentes genótipos, abordado anteriormente. Os valores estimados de proteínas e lipídeos não apresentaram grande variação (4\% para proteínas e 13\% para lipídeos). 
No entanto, para fibras a amostra BRS 332 apresentou valor $46 \%(5,83 \mathrm{~g} / 100 \mathrm{~g})$ superior que a amostra CMSXS 180. Preparações de pães sem glúten com diferentes concentrações de polvilho e farinha de arroz, obteve valor médio de $5 \mathrm{~g} / 100 \mathrm{~g}$ de fibras alimentares (NADAL, 2013). Outro estudo que avaliou 5 marcas de pão italiano sem glúten apresentou valores de fibras entre 3,2 e 6,3g/100g (LAUREATI, 2012). Onyango et al. (2009), ao utilizar um genótipo de sorgo com pericarpo vermelho para a formulação de pães encontrou quantidade de $1 \mathrm{~g} / 100 \mathrm{~g}$ de fibras totais, resultado muito inferior ao estimado no presente estudo.

Os pães elaborados com a farinha comercial e o genótipo 1167048 foram os que apresentaram estatisticamente maiores valores de amilose perante os demais, $18,1 \% \mathrm{e}$ 17,8\%, respectivamente. Em comparação com a composição das farinhas, o acréscimo significativo no teor de amilose deve se dever à adição de ingredientes como a fécula de batata e o polvilho doce por apresentarem quantidades consideráveis de amilose em sua constituição, aproximadamente $20 \%$ e $25 \%$, respectivamente. Com relação ao teor de amido resistente, houve diferença significativa da preparação com a farinha elaborada com o genótipo BR 305 em relação aos demais pães $(2,54 \mathrm{~g} / 100 \mathrm{~g})$. Um estudo realizado por Liljeberg et al. (1995), avaliou a influência do tratamento térmico e o tempo na formação de amido resistente na produção de pães. Esse estudo demonstrou que baixas temperaturas, assim como, elevado tempo de preparo são fator que contribuem positivamente para o aumento no teor de amido resistente nas preparações. De acordo com Walter et al. (2005), o amido resistente nos alimentos pode ser classificado em três tipos, sendo eles, amido fisicamente inacessível (Tipo 1), grânulos de amido resistente (Tipo 2) e amido retrogradado (Tipo 3). Desses, o Tipo 3 está relacionado diretamente com o aumento no teor de amido resistente relatado por Liljeberg na panifinação, pois 
ao ser submetido a um processo envolvendo calor e umidade o teor de amilose sofre retrogradação formando amido resistente (WALTER et al., 2005). O teor de amido resistente determinado nas preparações foi superior ao valor o estimado utilizando-se a composição das farinhas de sorgo. Entre os fatores prováveis, a retrogradação da amilose, alterações na interação com taninos (BARROS et al., 2012) ou a interferência do amido resistente de outros ingredientes podem ser destacados.

Os genótipos BR 305 e 116748 obtiveram teor de fenólicos totais de 469 e $320 \mathrm{mg} / 100 \mathrm{~g}$ e taninos de 188 e $103,6 \mathrm{mg}$ de proantocianidina/100g, respectivamente. Essas linhagens se destacaram frente aos demais por apresentarem teor de taninos até 18,8 vezes maior que os outros pães. Com relação à atividade antioxidante por DPPH, avaliando-se o efeito do processamento dessa variável pode-se observar que as amostras em sua maioria apresentaram mesmos valores de atividade antioxidante entre as linhagens estudadas e também inferior ao encontrado nas farinhas. Pode-se sugerir que a alta temperatura empregada no preparo dos pães pode ser responsável pela diminuição de sua atividade antioxidante (HAMAMA \& NAWAR, 1991). Morais (2011), avaliou a atividade antioxidante de 7 variedades dentre as quais coincidiu com os resultados encontrados nesse estudo. Ele observou queda significativa em todas variáveis $(36 \%$ a $86 \%$ ) com a realização de tratamento térmico em estufa e posterior produção de pipoca.

No entanto, quando avaliamos a atividade antioxidante pelo método FRAP, a amostra de pão produzida com o genótipo BR 305 obteve um grau de atividade estatisticamente superior aos demais. Khan et al. (2015) avaliou o impacto da atividade antioxidante in vivo de preparações com sorgos bronze e branco. Foram elaboradas duas formulações de massa com $30 \%$ de sorgo e comparadas a uma formulação padrão sem sorgo. Os resultados encontrados sugeriram um aumento de marcadores plasmáticos de 
antioxidantes e estresse oxidativo nos sujeitos estudados que ingeriram a preparação com sorgo bronze. Esse resultado condiz com o encontrado no presente estudo.

Cardoso et al. (2015), avaliou o conteúdo e a estabilidade de compostos e capacidade antioxidante pelo método ORAC de três ganótipos de sorgo (SC 319, SC 291, B.DLO 357) após tratamento térmico em forno convencional ou extrusão. O genótipo SC 391 foi o único a apresentar teor estatisticamente superior de fenólicos totais. Observou-se que a cocção em forno convencional não apresentou diminuição estatística considerável quando comparado ao grão cru. Sua capacidade antioxidante foi melhor preservada do que quando extrusado. Isso condiz com o presente estudo e presume-se que sua manutenção esta intrinsicamente relacionada ao genótipo utilizado e ao processamento empregado. 
Tabela 5. Valores de composição estimada, compostos bioativos e atividade antioxidante dos pães elaborados em comparação com o pão comercial

\begin{tabular}{|c|c|c|c|c|c|c|c|c|c|c|c|c|c|}
\hline \multirow[t]{2}{*}{ Genótipo } & \multirow{2}{*}{$\begin{array}{c}\text { Proteínas } \\
(\mathrm{g} / 100 \mathrm{~g})\end{array}$} & \multirow{2}{*}{$\begin{array}{l}\text { Lipídios } \\
\text { (g/100g) }\end{array}$} & \multirow{2}{*}{$\begin{array}{c}\begin{array}{c}\text { Fibras } \\
(\mathrm{g} / 100 \mathrm{~g})\end{array} \\
\text { Estimado }\end{array}$} & \multicolumn{2}{|c|}{$\begin{array}{l}\text { Amido Resistente } \\
\qquad(\mathrm{g} / 100 \mathrm{~g})\end{array}$} & \multirow{2}{*}{$\begin{array}{c}\text { Amido } \\
\text { Solúvel } \\
\text { (g/100g) } \\
\text { Determinado }\end{array}$} & \multirow{2}{*}{$\begin{array}{c}\text { Amilose (\%) } \\
\text { Determinado }\end{array}$} & \multicolumn{2}{|c|}{$\begin{array}{c}\text { Fenólicos Totais (mg } \\
\text { AGE/100g) }\end{array}$} & \multicolumn{2}{|c|}{$\begin{array}{c}\text { Taninos Totais (mg } \\
\text { PE/100g) }\end{array}$} & \multirow{2}{*}{$\begin{array}{l}\text { DPPH EC50 } \\
(\mu \mathrm{g} / \mathrm{g})\end{array}$} & \multirow{2}{*}{$\begin{array}{c}\begin{array}{c}\text { FRAP }(\mu \mathrm{M} \\
\text { trolox } / g)\end{array} \\
\text { Determinado }\end{array}$} \\
\hline & & & & Determinado & Estimado & & & Determinado & Estimado & Determinado & Estimado & & \\
\hline Comercial & $5,60^{*}$ & $5,11^{*}$ & $4,79^{*}$ & $0,00^{\mathrm{L}} \pm 0,00$ & $0,00^{*}$ & $55,9^{A} \pm 3,95$ & $18,1^{A} \pm 0,16$ & $0,00^{\mathrm{E}} \pm 0,00$ & $45,6^{*}$ & $10,4^{\mathrm{U}} \pm 0,21$ & $3,06^{*}$ & $14,0^{\mathrm{B}} \pm 1,13$ & $29,1^{\mathrm{U}} \pm 6,0$ \\
\hline BRS332 & $5,80^{*}$ & $4,79^{*}$ & $5,83^{\star}$ & $1,86^{\mathrm{B}} \pm 0,16$ & $0,23^{*}$ & $48,3^{\mathrm{B}} \pm 1,16$ & $15,6^{\mathrm{C}} \pm 0,06$ & $226^{\mathrm{C}} \pm 8,80$ & $49,3^{*}$ & $20,9^{\mathrm{C}} \pm 1,60$ & $7,01^{*}$ & $15,9^{A} \pm 0,57$ & $84,3^{\mathrm{C}} \pm 3,0$ \\
\hline BR305 & $5,85^{*}$ & $5,04^{*}$ & $4,43^{*}$ & $2,54^{A} \pm 0,07$ & $1,29^{*}$ & $47,8^{\mathrm{B}} \pm 1,82$ & $15,6^{\mathrm{C}} \pm 0,19$ & $469^{A} \pm 14,4$ & $590,7^{*}$ & $188,0^{A} \pm 8,55$ & $211,7^{*}$ & $14,1^{B} \pm 0,28$ & $217,6^{\mathrm{A}} \pm 22,7$ \\
\hline BRS330 & $5,85^{*}$ & $5,11^{*}$ & $4,20^{*}$ & $0,42^{\mathrm{C}} \pm 0,01$ & $0,30^{*}$ & $49,1^{\mathrm{B}} \pm 0,15$ & $15,1^{\mathrm{D}} \pm 0,18$ & $227^{\mathrm{C}} \pm 2,60$ & $56,4^{*}$ & $18,3^{\mathrm{CD}} \pm 1,05$ & $7,31^{*}$ & $14,4^{\mathrm{AB}} \pm 0,16$ & $126,8^{\mathrm{B}} \pm 19,2$ \\
\hline 1167048 & $5,62^{*}$ & $5,44^{*}$ & $4,30^{*}$ & $1,64^{\mathrm{B}} \pm 0,20$ & $0,12^{*}$ & $47,2^{\mathrm{B}} \pm 0,71$ & $17,8^{\mathrm{A}} \pm 0,24$ & $320^{\mathrm{B}} \pm 11,5$ & $298,4^{*}$ & $103,6^{\mathrm{B}} \pm 4,63$ & $121,8^{*}$ & $13,1^{\mathrm{B}} \pm 0,20$ & $127,5^{\mathrm{B}} \pm 0,2$ \\
\hline CMSXS180 & $5,79^{*}$ & $4,95^{\star}$ & $3,99^{*}$ & $0,28^{\mathrm{C}} \pm 0,04$ & $0,00^{*}$ & $48,1^{\mathrm{B}} \pm 2,46$ & $16,6^{\mathrm{B}} \pm 0,29$ & $175^{\mathrm{D}} \pm 11,1$ & $15,9^{*}$ & $12,5^{\mathrm{CD}} \pm 1,06$ & $5,42^{*}$ & $13,9^{\mathrm{B}} \pm 1,18$ & $54,8^{\mathrm{D}} \pm 0,5$ \\
\hline
\end{tabular}

Valores constituem médias \pm desvios padrão $(n=3)$. Em uma mesma coluna, médias com letras iguais não apresentam diferenças significativas pelo teste de Tukey $(p \leq 0,05)$. Valores com * contituem estimativa da composição baseada na Tabela Brasileira de Composição dos alimentos. 
Análise de regressão PLS foi conduzida para avaliação das correlações entre as vitreosidade e o peso de 1000 grãos, e as variáveis de composição e atividade antioxidante das farinhas (Figura 6). Trata-se de uma técnica de análise de dados multivariados que relaciona a matriz de dados $\mathrm{X}$ (variável independente) com uma resposta Y (variável resposta) permitindo encontrar vetores base representando a relação entre as variáveis (WESTAD, 2004). Desse modo, as variáveis próximas umas das outras no mapa gerado estão inter-relacionadas e as variáveis mutuamente distantes não estão relacionadas, ou estão negativamente relacionadas.

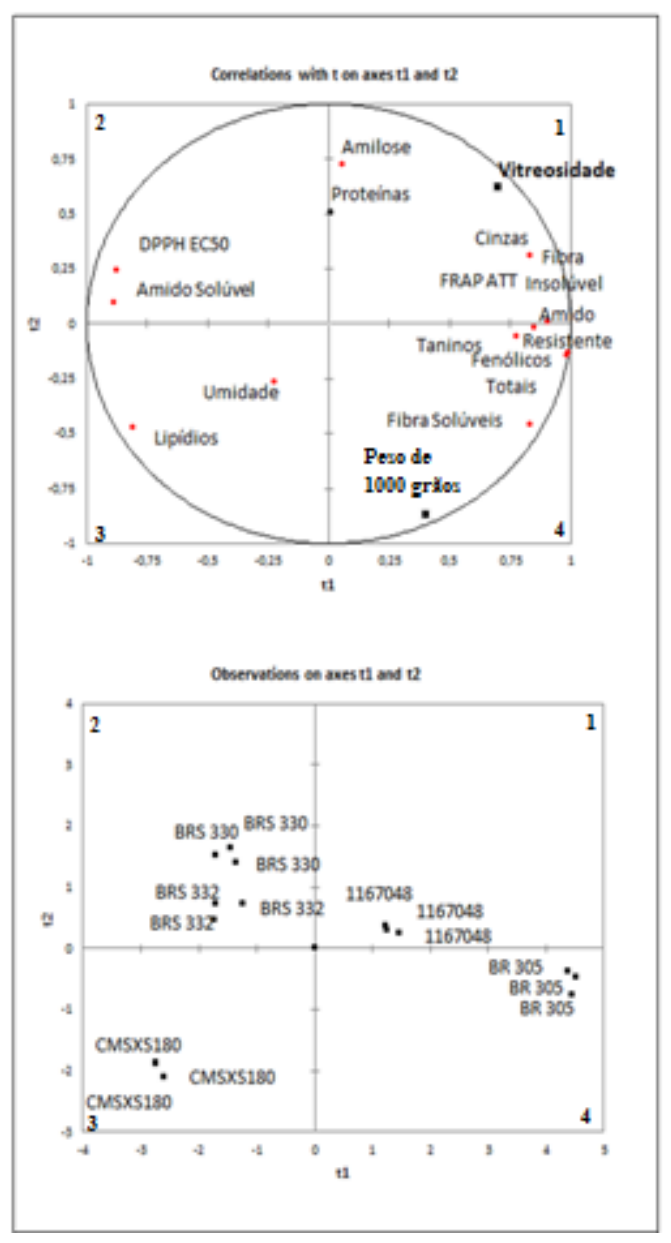

Figura 6. Regressão PLS da composição das farinhas de sorgo e das características físicas dos grãos (vitreosidade e massa de 100 grãos). 
Na parte superior da figura está apresentado o gráfico referente à relação entre as variáveis independentes (vitreosidade e peso de 1000 grãos) e as variáveis resposta (composição e atividade antioxidante). No primeiro quadrante, observou-se uma associação entre vitreosidade, cinzas, proteínas e o teor de amilose. Essa relação está quantificada na Tabela 6, onde estão presentes os parâmetros do modelo da regressão. A associação entre cinzas apresentou-se como sendo mais positiva que as demais $(32,087)$ e lipídeos como sendo a mais negativa $(-5,469)$. Esse resultado confirma o apresentado anteriormente de que a vitreosidade está relacionada com uma maior densidade do grão e menor porção farinácea.

Com relação ao peso de 1000 grãos, no quadrante 4, observa-se possivel correlação com o teor de fibras solúveis, no entanto, ao se analisar os dados da tabela 6 não se observou associação consideravelmente positiva ou negativa. Dessa forma, podese concluir que essa variável não está relacionada diretamente com a composição nutricional e no teor de antioxidantes para esse tipo de alimento

Também pode-se observar na primeira dimensão do mapa (quadrantes 1 e 4) que os compostos bioativos (compostos fenólicos, taninos, amido resistente e fibras) assim como com a atividade antioxidante por FRAP apresentaram-se aglomerados. Deve-se observar que a atividade antioxidante, por tratar-se de uma metodologia por $\mathrm{IC}_{50}$ (quantidade de amostra necessária para diminuir a oxidação), apresentou-se oposta aos demais dados por ser inversamente proporcional. 
Tabela 6. Relação entre as variáveis resposta e as variáveis independentes de vitreosidade (\%) e massa de 1000 grãos (g)

Parâmetros do Modelo

\begin{tabular}{lcc}
\hline \multicolumn{1}{c}{ Variável } & $\begin{array}{c}\text { Vitreosidade } \\
(\%)\end{array}$ & $\begin{array}{c}\text { Massa de 100 } \\
\text { Grãos (g) }\end{array}$ \\
\hline Intercept & 30,887 & 4,532 \\
Umidade (g/100g) & $-5,289$ & 0,016 \\
Cinzas (g/100g) & 32,087 & $-0,158$ \\
Proteínas (g/100g) & 5,261 & $-0,263$ \\
Lipídios (g/100g) & $-5,469$ & 0,118 \\
Fibra Insolúvel (g/100g) & $-0,038$ & $-0,016$ \\
Fibra Solúveis (g/100g) & $-0,843$ & 0,151 \\
Amido Resistente (g/100g) & 0,124 & $-0,012$ \\
Amido Solúvel (g/100g) & $-0,010$ & $-0,001$ \\
Amilose (g/100g) & 2,396 & $-0,026$ \\
Fenólicos Totais (mg/100g) & 0,002 & 0,000 \\
Taninos (mg de & 0,006 & 0,000 \\
proantocianidina/100g) & & $-0,009$ \\
DPPH EC50 ( $\mu \mathrm{M}$ Teq/g) & $-0,059$ & 0,000 \\
FRAP ATT (mM Teq/ g) & 0,006 & \\
\hline
\end{tabular}

Na parte inferior da Figura 6 está representada a associação entre os diferentes genótipos utilizados. Como o esperado, houve associação positiva entre as cultivares com as mesmas pigmentações. Os genótipos com pericarpo marrom (BR 305 e 1167048) e com pericarpo bronze (BRS 332 e BRS 330) apresentaram-se opostos ao genótipo de pericarpo branco (CMSXS 180).

Com base nos dados obtidos com a regressão, observa-se que os genótipos com pericarpo de coloração semelhante tendem a apresentar parâmetros próximos de composição. Esse fator é importante, pois pode vir a nortear estudos futuros para estabelecimento de aptidões tecnológicas para genótipos com determinadas características físicas e químicas. 


\section{CONCLUSÃO}

Os genótipos de sorgo BR 305 e 116748 apresentaram elevada concentração de compostos bioativos (fenólicos totais e taninos totais) e consecutivamente atividade antioxidante (DPPH e FRAP). O BR 305 se sobressaiu por também apresentar valores superiores de fibras e amido resistente. Observou-se redução na atividade antioxidante após o preparo dos pães. Seus teores mais elevados de amido resistente também indicam potencial para a produção de pães sem glúten. Dessa forma, as diferenças entre os genótipos de sorgo quanto à presença e atividade de compostos bioativos foram mapeadas e monitoradas da farinha aos pães produzidos. O preparo dos pães diminuiu sua concentração, cabendo considerar que os pães genótipos com maior retenção de compostos antioxidantes eram provenientes de farinhas mais ricas nestes compostos e, portanto, sua aplicação deve ser recomendada para avaliação da funcionalidade deste alimento. No entanto, mais estudos devem ser feitos objetivando-se também aspectos tecnológicos e sensoriais da variação da composição das farinhas sobre a qualidade dos pães. 


\section{REFERÊNCIAS}

AACC International. 2000. Approved Methods of the American Association of Cereal Chemists, 10th Ed. Methods 76-13 and 76-31. The Association: St. Paul, MN.

ABOUBACAR A., YAZICI N., HAMAKER B. R. Extent of decortication and quality of flour, couscous and porridge made from different sorghum cultivars. International Journal of Food Science and Tecnology, 41(6), 698-703, 2006.

ACELBRA - Associação dos Celíacos do Brasil. A Doença Celíaca de hoje. Disponível em: < http://www.acelbra.org.br/2004/doencaceliaca.php>. Acesso em: 5 de fev. 2015.

ADAMS, J.; WILLIAMS, A.; LANCASTER, B.; FOLEY, M. Advantages and uses of check-all-that-apply response compared to traditional scaling of attributes for salty snacks. In 7th Pangborn sensory science symposium, 12-16 August 2007, Minneapolis, USA.

ALMEIDA, O. P. Pão de forma sem glúten a base de farinha de arroz. 2011. 289 f. Tese (Doutorado em Tecnologia de Alimentos) - Faculdade de Engenharia de Alimentos, Universidade Estadual de Campinas, Campinas, 2011.

ANDRADE, A. A.; COELHO, S.V. ; MALTA, Hélia Lucila ; JORGE, M.N. . Avaliação sensorial de panificação enriquecidos com farinha de feijão branco para pacientes celíacos. Nutrir Gerais - Revista Digital de Nutrição, v. 05, p. 727-739, 2011.

ANGLANI, C. Sorghum carbohydrates - A review. Plant Foods Human .utr., v. 52, p. 77-83, 1998.

ANVISA - Agência Nacional de Vigilância Sanitária, Resolução RDC nº 90, 2000. Regulamento técnico de padrão de identidade e qualidade do pão. www.anvisa.gov.br Acesso em janeiro de 2015.

AOAC.“Official Methods of Analysis,"Association of Official Analytical Chemists methods, AOAC 16th Edition. Washington DC. 1995. 
AOAC.“Official Methods of Analysis”, Association of Official Analytical Chemists methods, AOAC 20th Edition. Washington DC. 2002.

ARAÚJO H, ARAÚJO W, BOTELHO R, ZANDONADI R. Celiac disease, eating habits and practices and life quality of life. Rev Nutr Campinas 2010; 23: 467-474.

ARAÚJO, H. M. C. Impacto da doença celíaca na saúde, nas práticas alimentares e na qualidade de vida dos celíacos. 2008. 97 f. Tese (Mestrado em Nutrição Humana) Programa de Pós Graduação em Nutrição Humana, Universidade de Brasília, Distrito Federal. 2008.

ARAÚJO, W.M.C.; MONTEBELLO, N.P.; BOTELHO, R.B.A.; BORGO, L.A. Alquimia dos Alimentos. Brasília: Editora Senac-DF, 2007.

ARES, G.; ETCHEMENDY, E.; ANTÚNEZ, L.; VIDAL, L.; IMÉNEZ, A.; JAEGER, S. R.. Visual attention by consumers to check-all-that-apply questions: Insights to support methodological development. Food Quality and Preference, v. 32, p. 210-220, 2014.

AWIKA, J. M.; ROONEY, L. W. Sorghum phytochemicals and their potential aspects on human health. Phytochemistry, Elmsford, v. 65, p. 1199-1221, 2004.

AWIKA, J. M.; YANG, L.; BROWNING, J. D.; FARAJ, A. Comparative antioxidant, antiproliferative and phase II enzyme inducing potential of sorghum (Sorghum bicolor) varieties. LWT - Food Science and Technology. v. 42, p. 1041-1046, 2009.

BÉCUE-BERTAUT, M.; PAGES, J. Multiple factor analysis and clustering of a mixture of quantitative, categorical and frequency data. Computational Statistics \& Data Analysis, v. 52, p. 3255-3268, 2008.

BARROS, F.; AWIKA, J. M. ; ROONEY, L. W. . Interaction of Tannins and Other Sorghum Phenolic Compounds with Starch and Effects on in Vitro Starch Digestibility. Journal of Agricultural and Food Chemistry, v. 60, p. 11609-11617, 2012.

BOSWELL, S. E. Development of gluten-free bread baking methods utilizing sorghum flour, 2010, p. 4-9, Tese (Mestrado em Ciências) Texas A\&M University, Estados Unidos. 
BRAND-MILLER, J.; et al. Glycemic index, postprandial glycemia, and the shape of the curve in healthy subjects: analisys of a database of more than 1000 foods. American Journal Clinical Nutrition, v.89, n. 1, p. 97-105, 2009.

BRAND-WILLIAMS, W.; CUVELIER, M.E.; BERSET, C. Use of a free radical method to evaluate antioxidant activity, Food Science and Technology, v.28, p. 25-30, 1995.

CARDOSO, L.M.; PINHEIRO, S.S.; DA SILVA, L.H.; MENEZES, C.B.; CARVALHO, C.W.P.; TARDIN, F.D.; QUEIROZ, V.A.V.; MARTINO, H.S.D.; PINHEIRO-SANT'ANA, H.M. Tocochromanols and carotenoids in sorghum (Sorghum bicolor L.): Diversity and stability to the heat treatment. Food Chemistry, v. 172, p. 900-908, 2015.

CHOI CW, KIM SC, HWANG SS, CHOI BK, AHN HJ, LEE MY, PARK SH, KIM SK 2002. Antioxidant activity and free radical scavenging capacity between Korean medicinal plants and flavonoids by assay-guided comparison. Plant Sci 163: 1161-1168 CORREA, C.E.S.; SHAVER,, R.D.; PEREIRA, M.N.; LAUER, J.G.; KOHN, K. Relationship Between Corn Vitreousness and Ruminal In Situ Starch Degradability. Journal of Dairy Science, v.85, p. 3008-3012, 2002.

CORREIA, A. I. L.. Contribuição para a melhoria da qualidade nutricional do sorgo, 2010, p. 11-38, Tese (Doutorado em Bioquímica) Universidade de Aveiro, Portugal.

CRESPO PÉREZ L, CASTILLEJO DE VILLASANTE G, CANO RUIZ A, LEÓN F. Non-dietary therapeutic clinical trials in coeliac disease. European Journal of Internal Medicine. 2012;23(1):9-14.

DAMODARAN, S.; PARKIN, K. L.; FENNEMA, O. R. Química de Alimentos de Fennema. 4. ed., Porto Alegre: Artmed, 2010. 900 p.

DEGÁSPARI, C. H.; WASZCZYNSKYJ, N. Propriedades Antioxidantes de Compostos Fenólicos. Revista Visão Acadêmica, Curitiba, v. 5, n.1, p. 33-40, 2004.

DEMETRA: Alimentação, Nutrição \& Saúde, v. 8, p. 125-136, 2013. 
DICKO, M.H., GRUPPEN, H., TRAORÉ, A.S., VORAGEN, A.J., BERKEL, W. (2006) Sorghum grain as human food in Africa: relevance of content of starch and amylase activities. African Journal of Biotechnology, 5(5):384-395

DLAMINI, N. R.; TAYLOR, J.R.N.; ROONEY, L.W. The effect of sorghum type and processing on the antioxidant properties of African sorghum-based foods. Food Chemistry. v. 105, p.1412-1419, 2007.

EMBRAPA. Cultivo do sorgo. Disponível em: <http://www.cnpms.embrapa.br/publicacoes/sorgo_4_ed/ecofisiologia.htm>. Acesso em: 27 de jan. 2015.

FARREL, R.J.; KELLY, C.P. Celiac Sprue. New England Journal of Medicine. 2002; 346 (3): $180-7$

FASANO A, ARAYA M, BHATNAGAR S, CAMERON D, CATASSI C, DIRKS M, et al. Federation of International Societies of Pediatric Gastroenterology, Hepatology, and nutrition consensus report on celiac disease. J Pediatr Gastroenterol Nutr 2008; 47: 214-219.

FASANO A, BERTI I, GERARDUZZI T. Prevalence of celiac disease in at-risk and not-at-risk groups in the Unites States: a large multicenter study. Arch Intern Med 2003; 163: 286-92.

FENNEMA, O. R., DAMODARAN, S., PARKIN, K. L. Química de Alimentos de Fennema. Porto Alegre: Artmed, 4, p.235, 2010.

FIBRAS: Aditivos \& Ingredientes, São Paulo, n. 4, p. 24-25, set./out. 1999 apud POSSAMAI, T. N. Elaboração de pão de mel com fibra alimentar proveniente de diferentes grãos, sua caracterização físico-química, microbiológica e sensorial. 69p. Dissertação (Mestrado em Tecnologia dos Alimentos), Universidade Federal do Paraná, Curitiba, 2005.

FLANDRIN, J.L.; MONTANARI, M. História da alimentação. São Paulo: Estação Liberdade, 1998.

FREIXA, D.; CHAVES, G. Gastronomia no Brasil e no Mundo. São Paulo: Senac, 2008 . 
GALlE S, SCHWAB C, DAL BELLO F, COFFEY A, GÄNZLE M, ARENDT E. Influence of in-situ synthesized exopolysaccharides on the quality of gluten-free sorghum sourdough bread. Int J Food Microbiol 2012; 155: 105-112.

GALLO, M. Revolução Francesa: Volume I - O povo e o Rei (1774 - 1793). Editora: L\&PM, 2012. p.214-223.

GIUNTINI E. B., LAJOLO F. M., MENEZES E.W. Potencial de fibra alimentar em países íbero-americanos: alimentos, produtos e resíduos. Archivos Latino Americanos de Nutrición. Caracas, v.53., n. 1, p. 14-20, mar. 2003.

GONÇALVES, J.W. Pão e Circo, ou a morte do outro. Ver. Biblos, Rio Grande, v.21, p. 125-131, 2007.

GOÑI, I.; GARCIA, A.A.; SAURA-CALIXTO, F. A starch hydrolysis procedure to estimate glycemic index. Nutr Res. 1997; 17(3):427-37.

GREEN, P.H.; JABRI, B. Coeliac disease. Lancet 2003; 362: 383-91.

GÜLÇIN,I.; HUYUT, Z.; ELMASTAS,M.; ABOUL-ENEIN, H.Y. Radical scavenging and antioxidant activity of tannic acid. Arabian Journal of Chemistry. v. 3, p. 43-53, 2010.

HAMANA A. A., NAWAR W. W. Thermal decomposition of some phenolic antioxidants. Journal of Agricultural and Food Chemistry. V. 34, n. 4, p.1063-1069, 1991.

HARBONE, J. B. WILliANS, C. A. Advances in flavonoid research since 1992. Phytochemistry, v. 55, p. $481-504,2000$.

JUNIOR, C.D; VIVAS, D.V et al. Avaliação microbiológica de silagens de sorgo exclusivo ou em consórcio com gramíneas. Zootecnia do Futuro: Produção Animal Sustentável. São Paulo, Brasil, 2013.

KHAN I., YOUSIF A. M., JOHNSON S. K., GAMLATH S. Acute effect of sorghum flour-containing pasta on plasma total polyphenols, antioxidant capacity and oxidative stress markers in healthy subjects: A randomised controlled trial. Clinical Nutrition 34 (2015) $415 \mathrm{e} 421$ 
KUMAR V., ABBAS A.K., FAUSTO N.; MITCHELL R.N. Robbins patologia básica. 8. ed. Elsevier, 2005. 815p.

LILJEBERG H., AKERBERG A., BJIIRCK I. Resistant starch formation in bread as influenced by choice of ingredients or baking conditions. Food Chemistry, Vol. 56, No. 4, 389-394, 1996

LIMA, G. J. M. M. Grãos de Alto Valor Nutricional para a produção de Aves e Suínos: oportunidades e perspectivas. In: A PRODUÇÃO ANIMAL NA VISÃO DOS BRASILEIROS, 2001, Piracicaba, SP. Anais... Piracicaba: SBZ, 201. p. 178-194.

LIU, R. H. (2003). Health benefits of fruit and vegetables are from additive and synergistic combinations of phytochemicals. American Journal of Clinical Nutrition, 78, $517 \mathrm{~S}-520 \mathrm{~S}$.

MAHAN, L. KATHLEEN E STRUMP ESCOTT SYLVIA. KRAUSE: Alimentos, Nutrição e Dietoterapia. 12. ed. São Paulo: editora Elsevier, 2010. 681-686p.

MATOS, M.E. and ROSELL, C.M. Chemical composition and starch digestability of diferente gluten-free breads. Plant food for Human nutrition, v.66:p.224-230. 2011.

MAXSON, E.D.; FRYAR, W.B., ROONEY, L.W; KRISHNAPRASAD, M.N. Milling properties of sorghum grain with different proportions of corneous to floury endosperm. Cereal Chem., v.48, p.478-490, 1971.

MERRILL, A.L., WATT, B.K., 1973. Energy Value of Foods, Basis and Derivation (Revision). Agric. Handbook No. 74. US Department of Agriculture, Washington, DC.

MORAES É. A. Atividade antioxidante, qualidade proteica e potencial funcional de genótipos de sorgo disponíveis à alimentação humana. Dissertação (Mestrado), Viçosa, MG, 2011.

MORAES E. A., MARINELI R. S., LENQUISTE S. A., STEEL C. J., MENEZES C. B., QUEIROZ V. A. V., JÚNIOR M. R. M. Sorghum flour fractions: Correlations among polysaccharides, phenolic compounds, antioxidant activity and glycemic index. Food Chemistry 180 (2015) 116-123 
MOSKOWITZ, H.R. Product testing and sensory evaluation of foods - marketing and R \& D approaches. Westport: Food \& Nutrition Press, 1993.

MUTISYA, J., SUN, C., ROSENQUIST, S., BAGUMA, Y., JANSSON, C. (2009) Diurnal oscillation of SBE expression in sorghum endosperm. Journal of Plant Physiology, Stuttgart, 166:428-434

NOZELLA, E. Determinação de taninos em plantas com potencial forrageiro para ruminantes. 2001. 72f. Dissertação (Mestrado) - ESALQ, USP, Piracicaba, 2001.

ONYANGO C, UNBEHEND G, LINDHAUER M. Effect of cellulose-derivatives and emulsifiers on creep-recovery and crumb properties of gluten-free bread prepared from sorghum and gelatinised cassava starch. Food Res Int 2009; 42: 949-955.

PAREYT B., FINNIE S. M., PTUSEYS J. A., DELCOUR J. A. Lipids in bread making: sources, interactions, and inpact on bread quality. Journal of Cereal Science, v.54, p. 266-279, 2011.

PEREIRA, B. S.; PEREIRA, B. S.; CARDOSO, E. S.; MENDONÇA, J. O. B.; SOUSA, L. B.; SANTOS, M. P.; ZAGO, L.; FREITAS, S. M. L. Análise físico-química e sensorial do pão de batata isento de glúten enriquecido com farinha de chia. Demetra, Rio de Janeiro. V.8, p.125-136, 2013.

PIANA, C.F.B., CARVALHO, F.I.F. Trigo In: BARBIERI, R.L., STUMPF, E.R.T. Origem e Evolução de Plantas Cultivadas. Embrapa, p. 821-851, 2008.

PINELLI, L.L.O; ZANDONADI, R.P.; BOTELHO, R.B.A.; OLIVEIRA, V. R.; FIGUEIREDO, L.F.A. The use of sorghum to produce gluten-free breads: A systematic review. J Adv Nutr Hum Metab 2015; 2: e944.

PREICHARDT, L. D.; VENDRUSCOLO, C. T. ; GULARTE, M. A. ; MOREIRA, A. S. . Efeito da goma xantana nas características sensoriais de bolos sem glúten. Revista brasileira de tecnologia agroindustrial, v. 03, p. 70-76, 2009.

PRIOR, R.L.; FAN, E.; JI, H.; HOWELL, A.; NIO, C.; PAYNE, M.J.; REED, J. Multilaboratory validation of a standard method for quantifying proanthocyanidins in cranberry powders. Journal of the Science of Food and Agriculture, v.90, p. 1473-1478, 2010. 
PULIDO, R.; BRAVO, L.; SAURA-CALIXTO, F. Antioxidant activity of dietary as determined by a modified ferric reducing/antioxidant power assay. Journal Agriculture and Food Chemistry, v.48, p. 3396-3402, 2000.

QUEIROZ, V. A. V., C. S. D. SILVA, C. B. D. MENEZES, R. E. SCHAFFERT, F. F. M. GUIMARAES, L. J. M. GUIMARAES, P. E. D. O. GUIMARAES AND F. D. TARDIN. "Nutritional composition of sorghum [sorghum bicolor (L.) Moench] genotypes cultivated without and with water stress." Journal of Cereal Science 65: 103 $11,2015$.

QUEJI, M. F. D ; SCHEMIN, M. H.; TRINDADE, J. L. F. . Propriedades reológicas da massa de farinha de trigo adicionada de alfa-amilase. Publicado UEPG. Ciências Exatas e da Terra, Ciências Agrárias e Engenharias, v. 12, p. 21-29, 2006.

R.C. ANTUNES , N.M. RODRIGUEZ , L.C. GONÇALVES , J.A.S. RODRIGUES , L.G.R. PEREIRA, D.O. FONTES , I. BORGES , A.L.C.C. BORGES , E.O.S. SALIBa. Valor nutritivo de grãos de sorgo com diferentes texturas do endosperma para leitões. Arq. Bras. Med. Vet. Zootec., v.60, n.3, p.713-718, 2008

RAE, P.R. A história do trigo. Disponível em: <http://www.abitrigo.com.br >. Acesso em: 30 de julho de 2015.

RAMOS D. P., LEONEL M., LEONEL S. Amido resistente em farinhas de banana verde. v.20, n.3, p. 479-483, jul./set. 2009

RAMOS; RESENDE, P.F.. Influência de emulsificantes e da enzima transglutaminase no desenvolvimento de pães modeláveis sem glúten / Priscila Silva Rezende Ramos. Rio de Janeiro, 2013. 80 f.: il. color. ; $21 \mathrm{~cm}$

REVISTA-FI. Panificação: os ingredientes enriquecedores. Disponível em: <http://www.revista-fi.com/materias/114.pdf>. Acesso em: 1 de mar de 2015.

ROONEY, L. W.; AWIKA, J. M. Overview of products and health benefits of specialty sorghums. Cereal Foods World, v. 50, p. 109-2004

SAPONE A, BAI J, CIACCI C, DOLINSEK J, GREEN P, HADJIVASSILIOU M. Spectrum of gluten-related disorders: consensus on new nomenclature and classification. BMC Medicine 2012; 10: 13. 
SEIFRIED, H. E.; ANDERSON, D.E.; FISHER, E. I.; MILNER, J. A. A review of the interaction among dietary ontioxidants and reactive oxygen species. Journal of Nutritional Biochemistry, v. 18, p. 567-579, 2007.

SILVA, M. R., SILVA, M. A. A. P. Aspectos nutricionais de fitatos e taninos. Rev. Nutr., Campinas, 12(1): 5-19, jan./abr., 1999

SINGER C. S. Propriedades físico-químicas, reológicas, entalpicas e de panificação da farinha obtida de trigo inrradiado. São Paulo, 2006. 106p. Dissertação de Mestrado Engenharia Química - Escola Politécnica - Universidade de São Paulo.

SINGLETON, V.L.; ROSSI, J. A. Colorimetry of total phenolics with phosphomolybdic phosphotungstic acid reagents. American Journal of Enology and Viticulture, v, 16, p. 144-158,1965.

Sistemas de Produção de Sorgo. Embrapa Milho e Sorgo, n 2, $5^{\text {a }}$ edição. ISSN 1679012X, Versão Eletrônica. Set./2009 disponível em: <http://sistemasdeproducao.cnptia.embrapa.br/FontesHTML/Sorgo>. Acesso em: 12 de março de 2015.

SIVARAMAKRISHNAN, H. P.; SENGE, B.; CHATTOPADHYAY, P. K. Rheological properties of rice dough for making rice bread. Journal of Food Engineering, Kidlington, v. 62, n. 1, p. 37-45, 2004.

STERN, M.; CICLITIRA, P.; VAN ECKERT, R. Analysis and clinical effects of gluten in coeliac disease. European Journal Gastroenterol Hepatol 2001; 13: 741-7.

SULLINS, R. D.; ROONEY, L. W. Ligth and scanning electron microscopy studies of waxy and nonwaxy endosperm sorghum varieties. Cereal Chemistry, St. Paul, v. 52, n. 3, p. 361-366, May/June 1975.

TEIXEIRA N. C., QUEIROZ V. A. V., ROCHA M. C., AMORIM A. C. P., SOARES T. A. O., MONTEIRO M. A. M. , Menezes C. B., Schaffert R. E., Garcia M. A. V. T., JUNQUEIRA R. G. Resistant starch content among several sorghum (Sorghum bicolor) genotypes and the effect of heat treatment on resistant starch retention in two genotypes. Food Chemistry 197 (2016) 291-296 
TEIXEIRA, N. Doença Celíaca Atualizada. 2012. 47 f. Tese (Mestrado em Medicina) Ciclo de Estudos Integrados, Universidade da Beira Interior, Portugal. 2012.

WANISKA, R. D.; ROONEY, L. W. Strutcture and chemistry of the sorghum caryopsis. In: Sorghum: origin, history, technology and production. Hoboken: Wiley, p. 649-688, 2000.

WESTAD F. PLS regression for analysing two or more data tables: an overview of different approaches. Norwegian Food Research Institute, p. 47, 2004.

WOLEVER, T. et al. Measuring the glycemic index of foods: interlaboratory study. American Journal of Clinical Nutrition, v. 87, n. 1, p. 247S-257S, 2008. 


\section{ANEXO I}

\section{$\underline{\text { Vitreosidade de grãos }}$}

\section{- Objetivo}

Determinar o percentual vítreo do grão de sorgo

\section{- Procedimento}

Selecionar 9 grão íntegros da amostra a ser analisada. Com um estilete, realizar um corte transversal na porção central do grão cuidadosamente para não fragmenta-lo.

Posteriormente avaliar visualmente, utilizando a figura 1, e determinar o grau da porção vítrea (escura) do grão.

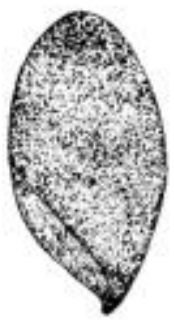

1

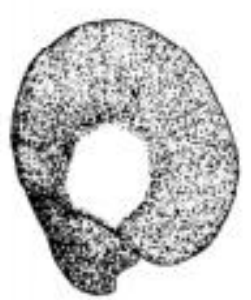

3

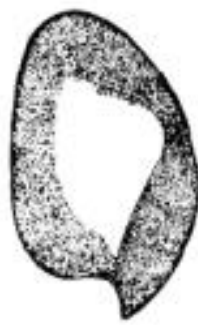

5

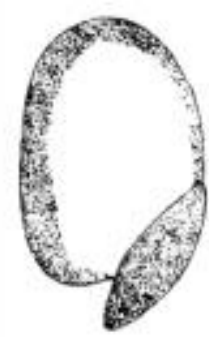

7

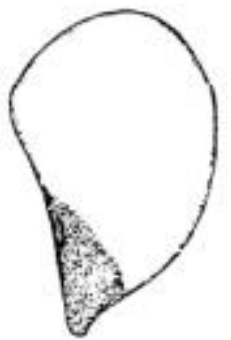

9

Fig. 6. Texture de l'endosperme

Frigura 01: Diferentes níveis de vitreosidade no grão.

Fonte: Descripteurs du Sorgho, Rome 1993.

\begin{tabular}{cc}
\hline Grau & Porção \\
\hline 1 & $100 \%$ \\
3 & $75 \%$ \\
5 & $50 \%$ \\
7 & $25 \%$ \\
9 & $0 \%$ \\
\hline
\end{tabular}




\section{ANEXO II}

\section{Análise de Umidade}

\section{- Objetivo}

Determinação do teor de umidade pelo método de gravimetria.

\section{- Referências Normativas}

Fonte: IAL. Instituto Adolfo Lutz. Normas analíticas do Instituto Adolfo Lutz: métodos químicos e físicos de composição de alimentos. 3. ed. São Paulo, 1985. v.1.

- Materiais e equipamentos:

Placa de petri

Dessecador

Estufa $65^{\circ} \mathrm{C}$ Com circulação de ar

Balança analítica - precisão $( \pm 0,0001 \mathrm{~g})$

Espátula de pesagem

\section{- Procedimento:}

Na placa de petri, pesar aproximadamente cinco gramas da amostra úmida em balança analítica e anotar o peso (P1).

Levar a placa de petri para a estufa à $65^{\circ} \mathrm{C}$ por $24 \mathrm{~h}$.

Tirar a placa da estufa e imediatamente colocar no dessecador para esfriar por 30 minutos.

Pesar a anotar os dados (P2).

- Cálculos:

$$
\mathrm{g} / 100 \mathrm{~g} \text { de umidade }=[(\mathrm{P} 1-\mathrm{P} 2) \mathrm{x} 100] / \mathrm{PA}
$$

Onde:

PA: peso da amostra úmida $(\sim 5 \mathrm{~g})$ 


\section{ANEXO III}

\section{Análise de Cinzas}

\section{- Objetivo}

Determinação do teor de sais inorgânicos no resíduo de fibra.

- Referências Normativas

Fonte: IAL. Instituto Adolfo Lutz. Normas analíticas do Instituto Adolfo Lutz: métodos químicos e físicos de composição de alimentos. 3. ed. São Paulo, 1985. v.1

- Materiais

Cadinho de porcelana previamente aquecido em forno Mufla a $550^{\circ} \mathrm{C}$ e tarado

Dessecador

Mufla $550^{\circ} \mathrm{C}$

Balança analítica - precisão $( \pm 0,0001 \mathrm{~g})$

Espátula de pesagem

Pinça para cadinho

\section{- Procedimento}

Pesar o cadinho previamente preparado (P1).

Pesar exatamente em torno de $3 \mathrm{~g}$ da amostra no cadinho.

Anotar o peso.

Incinerar em forno Mufla inicialmente a $50^{\circ} \mathrm{C}$ e a cada 20 minutos aumentar mais $50^{\circ} \mathrm{C}$ até atingir $550^{\circ}$.

Deixar incinerar até obter cinzas brancas $(\sim 3 \mathrm{~h})$.

Esfriar em dessecador e pesar (P2).

- Cálculo de cinzas

$$
\mathrm{g} / 100 \mathrm{~g} \text { de cinzas }=[(\mathrm{P} 2-\mathrm{P} 1) \times 100] / \mathrm{PA}
$$

Onde:

$\mathrm{CZ}=$ teor de cinzas

PA: peso da amostra úmida $(\sim 3 \mathrm{~g})$ 


\section{ANEXO IV \\ Procedimento de Análise de Proteína Bruta}

\section{- Objetivo}

Determinação do teor de proteína bruta - Kjeldahl.

\section{- Referências Normativas}

Fonte: AOAC."Official Methods of Analysis,"Association of Official Analytical Chemists methods, AOAC 16th Edition. Washington DC. 1995.

- Materiais

Balança analítica (precisão $0,1 \mathrm{mg}$ )

Papel vegetal

Bloco digestor (até $400^{\circ} \mathrm{C}$ )

Tubos de digestão macro

Dispensete

Destilador de Nitrogênio/Proteína

Bureta digital de 25 ou $50 \mathrm{~mL}$

Cilindro graduado de $1000 \mathrm{~mL}$

- Reagentes e soluções:

Ácido sulfúrico concentrado P.A. - (H2 SO4)

$200 \mathrm{~g}$ de sulfato de sódio P.A. - (Na2 SO4)

$20 \mathrm{~g}$ de sulfato de cobre P.A. - (CuSO4)

$2 \mathrm{~g}$ de selênio P.A - (Se)

Solução de hidróxido de sódio $40 \%$ - $(\mathrm{NaOH})$

Solução fatorada de ácido sulfúrico 0,05M - (H2 SO4)

Solução indicadora: $0,1 \%$ de verde de bromocresol $+0,2 \%$ de vermelho de metila

Solução de ácido bórico 5\% - (H3 BO3)

\section{- Preparo das soluções:}

Padronização da solução de Ácido sulfúrico 0,05M:

Pesar em erlenmeyer de $250 \mathrm{~mL}$, ao décimo de miligrama, cerca de $0,1 \mathrm{~g}$ de carbonato de sódio previamente seco. Adicionar algumas gotas de solução indicadora. Titular com solução de ácido sulfúrico 0,05 molar.

$$
\mathrm{M}=[(\mathrm{m} \times \text { pureza }) /(105,989 \times \mathrm{v})] \times 1000
$$


Onde:

$\mathrm{M}=$ molaridade da solução de $\mathrm{H} 2 \mathrm{SO} 4$

$\mathrm{m}(\mathrm{g})=$ peso de carbonato de sódio

$105,989=$ peso molecular do carbonato de sódio

$\mathrm{v}(\mathrm{ml})=$ volume de $\mathrm{H} 2 \mathrm{SO} 4$ gasto na titulação

Catalisador:

Triturar $350 \mathrm{~g}$ de sulfato de potássio P.A. e $0,35 \mathrm{~g}$ de selênio P.A., até obter mistura homogênea.

Solução de hidróxido de sódio 40\%:

Dissolver $800 \mathrm{~g}$ de $\mathrm{NaOH}$ em água destilada num balão volumétrico de 2L.

Solução de ácido bórico 5\%:

Dissolver $50 \mathrm{~g}$ de ácido bórico grau reagente em aproximadamente $500 \mathrm{~mL}$ de água destilada. Aquecer até que todo o ácido seja dissolvido. Esfriar e avolumar para $1000 \mathrm{~mL}$

Solução indicadora:

Dissolver 0,1 $\mathrm{g}$ de verde de bromocresol e avolumar para $100 \mathrm{~mL}$ com etanol 95\%. Dissolver 0,1 g de vermelho de metila e avolumar para $100 \mathrm{~mL}$ com etanol $95 \%$. Juntar as duas soluções e homogeneizar.

\section{- Procedimento:}

Adicionar cerca de $0,7 \mathrm{~g}$ de catalisador no tubo de digestão. Transferir cuidadosamente, com o auxílio de uma espátula apropriada, $3 \mathrm{~g}$ de amostra seca para o tubo de digestão Kjeldhal. Acrescentar $12 \mathrm{~mL}$ de ácido sulfúrico P.A.]

Colocar todos os tubos no bloco digestor e ajustar a temperatura para $100^{\circ} \mathrm{C}$, depois elevar $50^{\circ} \mathrm{C}$ a cada 30 minutos até $350^{\circ} \mathrm{C}$.

Deixar digerir até que o conteúdo do tubo se torne claro (verde ou azul claro e límpido). Após atingir este fase, deixar em digestão por mais 1 hora e esfriar até temperatura ambiente.

Levar o tubo de digestão ao destilador.

Adicionar $30 \mathrm{~mL}$ de solução de ácido bórico a $5 \%$ em erlenmeyer de 250 ou 300 mL, em seguida, no mínimo 4 gotas de indicador e colocar na saída do destilador.

Colocar $25 \mathrm{~mL}$ da solução de $\mathrm{NaOH} 40 \%$ no copo dosador do destilador, aguardar o início da produção de vapor e adicionar de uma só vez a solução de $\mathrm{NaOH}$ ao conteúdo do tubo de digestão.

Destilar até a virada da solução indicadora de rosa para verde. Após a virada, aguardar mais 10 minutos e interromper a destilação. 
Titular o destilado com a solução de $\mathrm{H} 2 \mathrm{SO} 4$ 0,05 molar padronizada até viragem de verde para rosa.

- Cálculo de Proteína (Ptn):

$$
\text { Ptn }=M \times V \times 0,028 \times F_{\text {alimento }}
$$

Onde:

$\mathrm{M}=$ molaridade do ácido sulfúrico utilizado

$\mathrm{V}=$ volume gasto de ácido

Falimento $=$ fator de conversão de proteína para alimentos $(6,25)$ 


\section{ANEXO V \\ Procedimento de Análise de Lipídeos}

\section{- Objetivo}

Determinação rápida de extrato etéreo utilizando extrator a alta temperatura

\section{- Referências Normativas}

Fonte: AOCS. American Oil Chemists' Society. Official Method Am 5-04, Rapid determination of oil/fat utilizing high temperature solvent extraction. Urbana: Official Methods and Recommended Pratices of the American Oil Chemists' Socity, 2005.

- Materiais e equipamentos:

Peneira 5 mesh $(4 \mathrm{~mm})$

Dessecador

Espátula de aço inox

Marcador para retroprojetor com tinta permanente

Papel toalha

Peneira

Pinça

Proveta de $250 \mathrm{~mL}$

Saquinhos Ankom® (Filter bag) XT4

Seladora

Suporte para pesagem

Suporte para extração

Balança analítica - precisão $( \pm 0,0001 \mathrm{~g})$

Estufa ajustada para $(102 \pm 2)^{\circ} \mathrm{C}$

Extrator de Gordura (Ankom ${ }^{\circledR}$ modelo XT10)

Termômetro com faixa de $60^{\circ} \mathrm{C}$ a $110^{\circ} \mathrm{C}$

- Reagentes e soluções:

Éter de petróleo, P.A.

\section{- Procedimento:}

O procedimento para determinação de extrato etéreo sob alta pressão e alta temperatura está descrito a seguir e está conforme proposto por AOCS (2005) e ANKOM (2009a).

Registrar o número da amostra em cada saquinho XT4 utilizando um marcador para retroprojetor com tinta permanente 
Pesar de 1,000 a 1,020 g de amostra, anotar o peso (P1) e selar o saquinho XT4 (filtro), utilizando uma seladora

Colocar as amostras para secar em estufa a $(102 \pm 2){ }^{\circ} \mathrm{C}$ por $3 \mathrm{~h}$, em uma peneira com malha de $4 \mathrm{~mm}$. Esta etapa pode ser usada na determinação da matéria seca

Deixar as amostras esfriando em dessecador até atingir a temperatura ambiente e pesar (P2)

Acomodar as amostras no equipamento e, com o auxílio de uma proveta, adicionar $200 \mathrm{~mL}$ de éter de petróleo no compartimento de extração e $150 \mathrm{~mL}$ de éter de petróleo no tubo de teflon

Em seguida, ligar o equipamento e selecionar o tempo de extração desejado (30 min, 40 min ou 50 min para avaliação)

Selecionar a temperatura de extração $\left(90^{\circ} \mathrm{C}\right)$

Após completar o processo de extração, retirar as amostras do extrator com o auxílio de uma pinça, acomodá-las na peneira de malha de $4 \mathrm{~mm}$, e colocar as amostras para secagem em estufa a $(102 \pm 2){ }^{\circ} \mathrm{C}$ por $30 \mathrm{~min}$

Deixar as amostras esfriando em dessecador até atingir a temperatura ambiente e pesar (P3).

\section{- Cálculos:}

$\mathrm{EE} \%=[(\mathrm{P} 2-\mathrm{P} 3) \times 100 / \mathrm{P} 1$ 


\section{ANEXO VI \\ Procedimento de Análise de Fibra Alimentar}

\section{- Objetivo}

Determinar o teor de fibra alimentar solúvel e insolúvel em produtos alimentícios

\section{- Referências Normativas}

Fonte: AOAC - 2005, método 985.29 (AOAC INTERNATIONAL, 2005)

- Materiais e equipamentos:

Balança analítica (precisão de $0,1 \mathrm{mg}$ )

Banho Dubnoff com regulagem de temperatura até $100^{\circ} \mathrm{C}$

Refrigerador mantido de $0-5^{\circ} \mathrm{C}$

Potenciômetro (pHmetro ou titulador automático) e padrões de calibração ( $\mathrm{pH}=7$ e $\mathrm{pH}=4$ )

Sistema de filtração à vácuo

Estufa à $105^{\circ} \mathrm{C}$

Mufla a $525-550^{\circ} \mathrm{C}$

Placa de aquecimento

Bécher de $400 \mathrm{~mL}$ de forma alta

Bécher de $1000 \mathrm{~mL}$ de forma alta

Papel de alumínio

Dessecador

Pipetador para $0,1 \mathrm{~mL}$ e $1 \mathrm{~mL}$ e ponteiras

Provetas graduadas de $50 \mathrm{~mL}$ e $500 \mathrm{~mL}$

Pipeta graduada de $10 \mathrm{~mL} \cdot$ Kitasato

Cadinho com placa de vidro sinterizado - Marca Pyrex de porosidade 40-60 ASTM, capacidade de $50 \mathrm{~mL}$

- Reagentes e soluções:

Acetona - $\mathrm{CH} 3(\mathrm{CO}) \mathrm{CH} 3$

Etanol a $95 \%$ - (C2H5OH)

Celite (auxiliar de filtração) - terra diatomácea com 87,5\% de SiO2 , 1,0\%; $\mathrm{Al} 2 \mathrm{O} 3$;

$6,6 \% \mathrm{CaO} ; 0,4 \% \mathrm{Fe} 2 \mathrm{O} 3$ e $1,5 \% \mathrm{Na} 2 \mathrm{O}+\mathrm{K} 2 \mathrm{O}$

Fosfato dibásico de sódio - (Na2HPO4)

Fosfato monobásico de sódio - (NaH2PO4 )

Solução de ácido clorídrico $5 \%$ - $(\mathrm{HCl})$

Solução de hidróxido de sódio $5 \%$ - $(\mathrm{NaOH})$

Enzimas:

a) alfa-amilase termo-estável - Termamyl - referência Sigma A-3306

b) protease - referência Sigma P-3910 
c) amiloglucosidase - referência Sigma A-9913 ou kit Sigma contendo as 3 enzimas TDF 100A

\section{- Procedimento:}

\section{1 - Fibra Insolúvel:}

Amostras que contêm mais de $10 \%$ de lipídios devem ser desengorduradas previamente com éter de petróleo. Caso se tenha necessidade de extrair a gordura de amostras úmidas, deve-se, primeiramente, realizar a determinação de umidade e registrar o resultado. Em seguida, deve-se determinar o teor de gordura por extração Soxhlet. O resultado do extrato etéreo obtido deve ser registrado.

\section{Lembrar que este procedimento deve ser computado no cálculo final.}

Ligar o banho Dubnoff, e fixá-lo em uma temperatura entre 95 e $100^{\circ} \mathrm{C}$. Verificar o nível da água, completando, se necessário, sempre com água destilada.

Separar 10 cadinhos para a análise ( 5 para fibra insolúvel e 5 para fibra solúvel) e adicionar $1 \mathrm{~g}$ de celite em cada cadinho. Colocá-los na mufla, ligá- la e ajustar a temperatura para $525-550^{\circ} \mathrm{C}$. Deixar na mufla por 1 hora, desligá-la e aguardar até que temperatura alcance $150^{\circ} \mathrm{C}$. Retirar os cadinhos para dessecador, esfriar até temperatura ambiente e pesar.

Observar que, para manter a vida útil do cadinho, deve-se ter cuidado em seu manuseio. O cadinho não deve ser exposto a mudanças bruscas de temperatura. $O$ aquecimento deve ocorrer de maneira gradual, assim como o resfriamento. Sugere-se o uso de mufla com programação de aquecimento e resfriamento.

Pesar, no mínimo 3 replicatas de amostra de $1 \mathrm{~g}$, com precisão de $0,1 \mathrm{mg}$, em bécher de forma alta de $400 \mathrm{~mL}$. As pesagens das porções teste não devem diferir mais do que $20 \mathrm{mg}$. Adicionar $50 \mathrm{~mL}$ da solução tampão fosfato $(\mathrm{pH}=6)$ em cada bécher e cobrir com papel alumínio. Usar mais 2 bécheres para o branco.

Colocar os 5 bécheres no banho-maria à $95-100^{\circ} \mathrm{C}$ e ligar a agitação $(100 \mathrm{rpm})$ por 20 minutos para gelatinizar o amido.

Parar a agitação, retirar o papel de alumínio e adicionar $0,1 \mathrm{~mL}$ da enzima Termamyl com o auxílio do pipetador. Cobrir novamente os bécheres com a folha de alumínio, ligar a agitação $(100 \mathrm{rpm})$ e mantê-los a $95-100^{\circ} \mathrm{C}$ por 35 minutos.

Remover as amostras do banho e deixar esfriar à temperatura ambiente. Caso necessite acelerar o resfriamento, colocar os bécheres em um banho de gelo em bandeja.

Calibrar o potenciômetro de acordo com o manual de calibração do equipamento. Remover os papéis de alumínio e mergulhar o eletrodo no bécher contendo a amostra. Ajustar o $\mathrm{pH}$ de cada amostra para 7,5 $\pm 0,1$. Usar inicialmente 2,0 a 2,5 $\mathrm{mL}$ de $\mathrm{NaOH}$ $5 \%$ para que se aproxime o máximo do valor desejado, depois ajustar gota a gota.

\section{Obs.: caso seja necessário ajustar o pH com $\mathrm{HCl} 5 \%$.}

Adicionar $0,1 \mathrm{~mL}$ da solução de protease. 
Cobrir os bécheres com papel de alumínio incubando sob contínua agitação (100 rpm), em banho-maria à $60^{\circ} \mathrm{C}$ por 30 minutos.

Remover as amostras do banho e resfriar à temperatura ambiente. Caso necessite acelerar o resfriamento, colocar os bécheres num banho de gelo em bandeja.

Remover os papéis alumínio. Mergulhar o eletrodo no bécher contendo a amostra.

Ajustar o pH de cada amostra para 4,3 $\pm 0,3$. Usar inicialmente $2,0 \mathrm{~mL}$ de $\mathrm{HCl} 5 \%$, para que se aproxime o máximo do valor desejado, depois ajustar gota a gota.

\section{Obs.: caso seja necessário ajuste o pH com $\mathrm{NaOH} 5 \%$.}

Adicionar $0,1 \mathrm{~mL}$ da solução de amiloglucosidase sob agitação e cobrir o bécher com papel de alumínio.

Incubar por 30 minutos com agitação $(100 \mathrm{rpm})$ em banho-maria à $60^{\circ} \mathrm{C}$.

Instalar o sistema de filtração conforme mostrado na figura 1: kitasato, funil, adaptadores de borracha e cadinhos filtrantes com celite tarados. Ligar o sistema na tubulação de vácuo.

Antes de iniciar a filtração das amostras, adicionar (aplicando vácuo) em cada cadinho etanol suficiente para formar um leito homogêneo de celite no interior do mesmo.

Filtrar as amostras através do sistema de filtração com o cadinho com filtro sinterizado + celite usando vácuo. Transferir quantitativamente todo o resíduo do bécher usando solução tampão fosfato. Usar o menor volume possível, a fim de prevenir um grande aumento do volume final.

Obs.: em algumas amostras um filme parecido com uma goma pode se formar impedindo a filtração. Caso isto ocorra, deve-se romper este filme com o auxílio de uma espátula ou bastão, sem, no entanto, alterar o leito de celite.

Nesta etapa obteremos 2 tipos de resíduos: 2 provenientes do branco e 3 provenientes da amostra.

\section{2 - Fibra Solúvel:}

Transferir quantitativamente o filtrado do kitasato para um bécher de $1000 \mathrm{~mL}$.

Lavar o resíduo 2 vezes com $15 \mathrm{~mL}$ de etanol 95\%, e depois 2 vezes com $15 \mathrm{~mL}$ de acetona. Colocar os cadinhos com os resíduos obtidos em estufa convencional a 100$105^{\circ} \mathrm{C}$ por 1 hora. Esfriar e pesar. Manter os cadinhos em dessecador para posterior determinação de cinzas e proteína.

Aquecer etanol $95 \%$ em banho-maria em placa de aquecimento ou em banho Dubnoff a $60^{\circ} \mathrm{C}$.

Adicionar o etanol aquecido em volume equivalente a 4 vezes o volume do filtrado.

Cobrir todos os bécheres com novas folhas de alumínio e deixar o precipitado se formar à temperatura ambiente por 1 hora.

Instalar o sistema de filtração conforme mostrado nas figuras 2 e 3: kitasato, funil, adaptadores de borracha e cadinhos filtrantes com celite tarados. Ligar o sistema na tubulação de vácuo. Antes de iniciar a filtração das amostras, adicionar alguns mililitros de etanol (aplicando vácuo) em cada cadinho de modo a formar um leito homogêneo de celite no interior do mesmo. 
Filtrar as amostras através do sistema de filtração com o cadinho com filtro sinterizado + celite usando vácuo. Transferir quantitativamente todo o resíduo do bécher usando etanol $95 \%$.

Lavar o resíduo 2 vezes com $15 \mathrm{~mL}$ de etanol 95\% e depois 2 vezes com $15 \mathrm{~mL}$ de acetona.

Obs.: em algumas amostras um filme parecido com uma goma pode se formar impedindo a filtração. Caso isto ocorra, deve-se romper este filme com o auxílio de uma espátula ou bastão, sem, no entanto, alterar o leito de celite

Transferir o filtrado do kitasato para a bombona de resíduos de solventes orgânicos.

Colocar os cadinhos com os resíduos obtidos em estufa convencional a $100^{\circ} \mathrm{C}$ por 1 hora. Esfriar e pesar.

Da precipitação da fibra insolúvel, selecionar 2 cadinhos de resíduo e 1 de branco para determinação de cinzas. Da precipitação da fibra solúvel, selecionar 2 cadinhos de resíduo e 1 de branco para determinação de cinzas. Da mesma forma serão selecionados os resíduos das fibras e brancos para a determinação de proteína.

Desta etapa serão obtidos os seguintes valores: peso do cadinho contendo cinzas do resíduo de fibra insolúvel da amostra; peso do cadinho contendo cinzas do resíduo de fibra solúvel da amostra; peso do cadinho contendo cinzas do resíduo de branco da análise de fibra insolúvel e peso do cadinho contendo cinzas do resíduo de branco da análise de fibra solúvel. Nos demais resíduos de fibra solúvel, fibra insolúvel, branco da fibra insolúvel e branco da fibra solúvel, serão obtidos os respectivos valores de proteína

\section{3 - Análise de Proteína}

\section{- Objetivo}

Determinar o teor de proteína total nos resíduos de fibra solúvel, insolúvel, branco de fibra insolúvel e branco de fibra solúvel e respectivos alimentos em geral.

\section{- Referência Normativa}

AACC -1995 (AMERICAN ASSOCIATION OF CEREAL CHEMISTS, 1995), método 46-13 modificado (catalisador sulfato de sódio ( $\mathrm{Na} 2 \mathrm{SO} 4)$, sulfato de cobre (CuSO4) e selênio(Se); titulante (H2 SO4 0,05M).

\section{- Materiais}

Balança analítica (precisão 0,1 mg)

Papel vegetal

Bloco digestor (até $400^{\circ} \mathrm{C}$ )

Tubos de digestão macro

Dispensete

Destilador de Nitrogênio/Proteína

Bureta digital de 25 ou $50 \mathrm{~mL}$

Cilindro graduado de $1000 \mathrm{~mL}$ 


\section{- Reagentes e soluções:}

Ácido sulfúrico concentrado P.A. - (H2 SO4)

$200 \mathrm{~g}$ de sulfato de sódio P.A. - (Na2 SO4)

$20 \mathrm{~g}$ de sulfato de cobre P.A. - (CuSO4)

$2 \mathrm{~g}$ de selênio P.A - (Se)

Solução de hidróxido de sódio $40 \%$ - $(\mathrm{NaOH})$

Solução fatorada de ácido sulfúrico $0,05 \mathrm{M}$ - (H2 SO4)

Solução indicadora: $0,1 \%$ de verde de bromocresol $+0,2 \%$ de vermelho de metila

Solução de ácido bórico 5\% - (H3 BO3)

\section{- Preparo das soluções:}

Padronização da solução de Ácido sulfúrico 0,05M:

Pesar em erlenmeyer de $250 \mathrm{~mL}$, ao décimo de miligrama, cerca de $0,1 \mathrm{~g}$ de carbonato de sódio previamente seco. Adicionar algumas gotas de solução indicadora. Titular com solução de ácido sulfúrico 0,05 molar.

$$
\mathrm{M}=[(\mathrm{m} \times \text { pureza }) /(105,989 \times \mathrm{v})] \times 1000
$$

Onde:

$\mathrm{M}=$ molaridade da solução de $\mathrm{H} 2 \mathrm{SO} 4$

$\mathrm{m}(\mathrm{g})=$ peso de carbonato de sódio

105,989 = peso molecular do carbonato de sódio

$\mathrm{v}(\mathrm{ml})=$ volume de $\mathrm{H} 2 \mathrm{SO} 4$ gasto na titulação

Catalisador:

Triturar $350 \mathrm{~g}$ de sulfato de potássio P.A. e 0,35 g de selênio P.A., até obter mistura homogênea.

Solução de hidróxido de sódio 40\%: 2L.

Dissolver 800 g de $\mathrm{NaOH}$ em água destilada num balão volumétrico de

Solução de ácido bórico 5\%:

Dissolver $50 \mathrm{~g}$ de ácido bórico grau reagente em aproximadamente $500 \mathrm{~mL}$ de água destilada. Aquecer até que todo o ácido seja dissolvido. Esfriar e avolumar para $1000 \mathrm{~mL}$

Solução indicadora:

Dissolver $0,1 \mathrm{~g}$ de verde de bromocresol e avolumar para $100 \mathrm{~mL}$ com etanol 95\%. Dissolver $0,1 \mathrm{~g}$ de vermelho de metila e avolumar para $100 \mathrm{~mL}$ com etanol 95\%. Juntar as duas soluções e homogeneizar. 


\section{- Procedimento:}

Adicionar cerca de $0,7 \mathrm{~g}$ de catalisador no tubo de digestão. Transferir cuidadosamente, com o auxílio de uma espátula apropriada, o material do cadinho (celite + resíduo) para o tubo de digestão Kjeldhal. Acrescentar $12 \mathrm{~mL}$ de ácido sulfúrico P.A.]

Realizar a análise de um branco para cada bateria de amostras.

Colocar todos os tubos no bloco digestor e ajustar a temperatura para $100^{\circ} \mathrm{C}$, depois elevar $50^{\circ} \mathrm{C}$ a cada 30 minutos até $350^{\circ} \mathrm{C}$.

Deixar digerir até que o conteúdo do tubo se torne claro (verde ou azul claro e límpido). Após atingir este fase, deixar em digestão por mais 1 hora e esfriar até temperatura ambiente.

Levar o tubo de digestão ao destilador.

Adicionar $30 \mathrm{~mL}$ de solução de ácido bórico a $5 \%$ em erlenmeyer de 250 ou 300 $\mathrm{mL}$, em seguida, no mínimo 4 gotas de indicador e colocar na saída do destilador.

Colocar $25 \mathrm{~mL}$ da solução de $\mathrm{NaOH} 40 \%$ no copo dosador do destilador, aguardar o início da produção de vapor e adicionar de uma só vez a solução de $\mathrm{NaOH}$ ao conteúdo do tubo de digestão.

Destilar até a virada da solução indicadora de rosa para verde. Após a virada, aguardar mais 10 minutos e interromper a destilação.

Titular o destilado com a solução de H2 SO4 0,05 molar padronizada até viragem de verde para rosa.

Desta etapa serão obtidos os seguintes valores: teor de proteínas do resíduo de fibra insolúvel da amostra; teor de proteínas do resíduo de fibra solúvel da amostra; teor de proteínas do resíduo de branco da análise de fibra insolúvel e teor de proteínas do resíduo de branco da análise de fibra solúvel.

\section{- Cálculo de Proteína (Ptn):}

$$
\text { Ptn }=\mathrm{M} \times \mathrm{V} \times 0,028 \times \mathrm{F}_{\text {alimento }}
$$

Onde:

$\mathrm{M}=$ molaridade do ácido sulfúrico utilizado

$\mathrm{V}=$ volume gasto de ácido

Falimento $=$ fator de conversão de proteína para alimentos $(6,25)$

\section{4 - Análise de Cinzas}

\section{- Objetivo}

Determinação do teor de sais inorgânicos no resíduo de fibra.

- Referências Normativas

AOAC 2005, $18^{\mathrm{a}}$ ed. - métodos: 923.03 (AOAC INTERNATIONAL, 2005) 
- Materiais

Cadinho de placa de vidro sinterizada com resíduo de fibra solúvel e insolúvel e branco

Mufla a $525-550^{\circ} \mathrm{C}$

Dessecador com sílica gel

Balança analítica (precisão de $0,1 \mathrm{mg}$ )

Pinça tenaz

\section{- Procedimento}

Colocar os cadinhos em mufla, ligá-la e ajustar a temperatura para $525-550^{\circ} \mathrm{C}$. Deixar aproximadamente por 5 horas, desligar a mufla e aguardar até que alcance $150^{\circ} \mathrm{C}$. Retirar os cadinhos para dessecador, esfriar até temperatura ambiente e pesar.

- Cálculo de cinzas

$$
\mathrm{Cz}=\mathrm{P} 1-\mathrm{P}
$$

Onde:

$\mathrm{CZ}=$ teor de cinzas

\section{5 - Cálculo final de Fibras}

- Cálculo da correção do branco da análise de fibra solúvel e insolúvel

$$
\text { Correção do Branco }=\mathrm{P}_{\mathrm{rb}}-\mathrm{Ptn}_{\mathrm{b}}-\mathrm{Cz}_{\mathrm{b}}
$$

Onde:

$\mathrm{PR}_{\mathrm{b}}$ (cadinho de resíduo de branco $\left.-\mathrm{P} 1\right)=$ massa dos resíduos do branco após secagem em estufa

$\operatorname{Ptn}_{\mathrm{b}}=$ teor de proteína calculado para o branco

$\mathrm{Cz}_{\mathrm{b}}=$ massa de cinzas obtida do branco

\section{- Cálculo da Fibra Alimentar Solúvel ou Insolúvel}

$$
\% \mathrm{FA}=\left[\left(\mathrm{P}_{\mathrm{ra}}-\mathrm{Ptn}_{\mathrm{a}}-\mathrm{Cz}_{\mathrm{a}}-\text { Correção do Branco }\right) / \mathrm{Pa}\right] \times 100
$$

Onde:

$\%$ FA - teor de fibra alimentar por $100 \mathrm{~g}$ de amostra

$\mathrm{PRa}=\mathrm{Pr}-\mathrm{P} 1=$ média dos resíduos das amostras

Ptna $=$ correção de proteínas

$\mathrm{Cza}=$ média das cinzas das amostras

Correção do branco = média dos resíduos obtidos

$\mathrm{Pa}=$ média dos pesos da amostra em gramas 


\section{ANEXO VII \\ Procedimento de Análise de Amido Resistente, Amido Solúvel e Amido Total}

\section{- Objetivo}

Determinação do teor amido resistente, amido solúvel e amido total através do métido enzimático.

\section{- Referências Normativas}

Megazyme International Ireland. Resistent Starch Assay Procedure - KRSTAR09/14 disponível em: < www.megazyme.com >.

ASSOCIATION OF OFFICIAL ANALYTICAL CHEMISTS. Official methods of analysis of AOAC.17th ed. Washington, 2002. $1 \mathrm{v}$.

\section{- Materiais e equipamentos:}

Moinho com abertura de peneira de 1,0 $\mathrm{mm}$

Balança analítica com a aproximação de $0,0001 \mathrm{~g}$

Agitador de tubos (vortex)

Suporte para tubos

Banho-maria com agitação a $37^{\circ} \mathrm{C}$

Centrífuga com capacidade de rotação de 3.000 x g

Banho-maria a $50{ }^{\circ} \mathrm{C}$

Espectrofotômetro UV/Visível operando a $510 \mathrm{~nm}$

pHmetro

Agitador magnético e recipiente para banho de gelo

Balões volumétricos de $1,0 \mathrm{~L}, 2,0 \mathrm{~L}$ e $100 \mathrm{~mL}$

Béqueres de 2,0 L e 1,0 L

Barras magnéticas de $15 \mathrm{~mm}$ x $5 \mathrm{~mm}$

Pipetas graduadas de vidro de $20,0 \mathrm{~mL}$

Pipetadores para volumes de $8 \mathrm{~mL}, 5 \mathrm{~mL}, 4 \mathrm{~mL}, 3 \mathrm{~mL}$ e $2 \mathrm{~mL}$

Micropipetas para volumes de $1000 \mu \mathrm{L}$ e $100 \mu \mathrm{L}$

Tubos de ensaio de vidro $16 \mathrm{~mm}$ x $100 \mathrm{~mm}$, capacidade $14 \mathrm{~mL}$

Tubo para centrífuga em polipropileno de $50 \mathrm{~mL}$

Parafilme

Temporizador digital

- Reagentes e soluções:

Acetato de sódio

Ácido acético

Ácido maleico

Álcool etílico 99\%

Azida sódica 
Cloreto de cálcio di-hidratado

Hidróxido de potássio

Hidróxido de sódio

Kit para determinação de Amido Resistente (K-RSTAR, Megazyme) composto por:

- Frasco 1: Amiloglicosidase $\left(3.300 \mathrm{U}\right.$ mL-1, estável a $4{ }^{\circ} \mathrm{C}$ por mais de três anos)

- Frasco 2: $\alpha$-Amilase pancreática (Pancreatina, 3 unid. Ceralpha/mg, estável a $-20^{\circ} \mathrm{C}$ por mais de três anos)

- Frasco 3: Concentrado para preparo de tampão para GOPOD (após diluição: tampão fosfato de potássio $1,0 \mathrm{~mol} \mathrm{L-1,} \mathrm{pH} 7,4$; ácido $\rho$ hidroxibenzoico $0,22 \mathrm{~mol} \mathrm{L-1}$; azida sódica $0,4 \%(\mathrm{p} / \mathrm{v})$, estável a $4{ }^{\circ} \mathrm{C}$ por mais de quatro anos)

- Frasco 4: Reagente com enzimas GOPOD (após diluição: glicose oxidase 12.000 U L-1; peroxidase $650 \mathrm{U} \mathrm{L}-1$; 4-aminoantipirine 0,4 mol L-1, estável a $-20{ }^{\circ} \mathrm{C}$ por mais de cinco anos)

- Frasco 5: Solução padrão de D-Glicose $(1,0 \mathrm{mg} / \mathrm{mL}$ em ácido benzóico $0,2 \%$, estável à temperatura ambiente por mais de cinco anos)

- Frasco 6: Controle para Amido Resistente (conteúdo de amido resistente descrito no frasco, variável entre lotes, estável em temperatura ambiente por mais de cinco anos).

\section{- Preparo das soluções:}

Tampão maleato de sódio (100 mmol L-1, pH 6,0) mais cloreto de cálcio 5 mmol L1 e azida sódica $0,02 \%(\mathrm{p} / \mathrm{v})$ :

Em béquer de 2,0 L, dissolver 23,2 g de ácido maleico em $1.600 \mathrm{~mL}$ de água destilada e ajustar o pH para 6,0, com solução de hidróxido de sódio 4,0 mol L-1 $(160 \mathrm{~g} / \mathrm{L})$. Adicionar $0,74 \mathrm{~g}$ de cloreto de cálcio dihidratado e $0,4 \mathrm{~g}$ de azida sódica e dissolver. Transferir para balão volumétrico de 2,0 L e ajustar o volume com água destilada. Solução estável por 12 meses a $4{ }^{\circ} \mathrm{C}$.

Tampão acetato de sódio 1,2 mol L-1, pH 3,8:

Adicionar 69,6 mL de ácido acético glacial $(1,05 \mathrm{~g} / \mathrm{mL})$ em $800 \mathrm{~mL}$ de água destilada e ajustar o pH para 3,8 usando solução de hidróxido de sódio 4,0 mol L-1. Transferir para balão volumétrico de 1,0 L e ajustar o volume com água destilada. Solução estável por 12 meses à temperatura ambiente.

Tampão acetato de sódio 100 mmol L-1, pH 4,5

Adicionar 5,8 mL de ácido acético glacial em $900 \mathrm{~mL}$ de água destilada e ajustar o pH para 4,5, usando solução de hidróxido de sódio 4,0 mol L-1. Transferir para balão volumétrico de $1,0 \mathrm{~L}$ e ajustar o volume com água destilada. Solução estável por dois meses a $4{ }^{\circ} \mathrm{C}$.

Hidróxido de potássio 2,0 mol L-1:

Adicionar 112,2 g de hidróxido de potássio em $900 \mathrm{~mL}$ de água deionizada e dissolver sob agitação. Transferir para balão volumétrico de $1,0 \mathrm{~L}$ e ajustar o 
volume com água deionizada. Solução estável por mais de dois anos à temperatura ambiente.

Álcool etílico 50\% (v/v):

Adicionar $500 \mathrm{~mL}$ de etanol $99 \%$ em $500 \mathrm{~mL}$ de água destilada. Solução estável por mais de dois anos à temperatura ambiente.

Amiloglicosidase (AMG) diluída 300 U mL-1:

Homogeneizar 2,0 mL da amiloglicosidase concentrada (Frasco 1) em 20,0 $\mathrm{mL}$ de tampão maleato de sódio $(0,1 \mathrm{~mol} \mathrm{L-1,} \mathrm{pH} \mathrm{6,0),} \mathrm{obtendo} \mathrm{volume} \mathrm{final} \mathrm{de}$ 22,0 mL. Dividir em alíquotas de 5,0 mL em tubos de polipropileno e congelar. Solução estável por cinco anos a $-20{ }^{\circ} \mathrm{C}$. Estável também durante repetidos ciclos de congelamento e descongelamento.

$\alpha$-Amilase pancreática $10 \mathrm{mg} / \mathrm{mL}$ e amiloglicosidase $3 \mathrm{U} \mathrm{mL}-1$ :

Imediatamente antes do uso, suspender $1,0 \mathrm{~g}$ de $\alpha$-amilase pancreática (Frasco 2) em $100 \mathrm{~mL}$ de tampão maleato de sódio (100 mmol L-1, pH 6,0) e agitar em vortex durante cinco minutos. Adicionar $1,0 \mathrm{~mL}$ de amiloglicosidase diluída (300 U mL-1) e misturar bem. Centrifugar por dez minutos a $3.000 \mathrm{x} \mathrm{g}$. Usar o sobrenadante no dia de seu preparo.

Nota: É aconselhável preparar aproximadamente a quantidade necessária para as amostras analisadas no dia, evitando assim o desperdício das enzimas.

Reagente GOPOD (reagente de determinação de glicose)

Em balão volumétrico de 1,0 L, dissolver o conteúdo do Frasco 3 (concentrado para tampão) em água destilada e aferir o volume. Usar $20 \mathrm{~mL}$ desta solução para dissolver o conteúdo do Frasco 4 (reagente enzimas GOPOD) e, quantitativamente, transferir para béquer de 1,0 L contendo o restante da solução tampão para GOPOD, já diluída (usar a solução tampão para lavar o Frasco 4). Armazenar em frasco âmbar ou coberto por papel alumínio. Estável por três meses à temperatura de $2{ }^{\circ} \mathrm{C} \mathrm{a} 5{ }^{\circ} \mathrm{C}$, ou por mais de 12 meses a $-20{ }^{\circ} \mathrm{C}$. Dividir em alíquotas antes de armazenar a $-20{ }^{\circ} \mathrm{C}$, pois, uma vez descongelada, a solução deve ser imediatamente usada. Quando recém-preparado, o reagente pode apresentar cor amarelo-claro ou rosa-claro. O reagente desenvolve coloração rosa-escuro após dois a três meses a $4{ }^{\circ} \mathrm{C}$. A absorbância desta solução deve ser menor que 0,05 quando lida a $510 \mathrm{~nm}$, usando água destilada como branco.

- Procedimento 
Nota: É recomendável analisar uma amostra controle (Frasco 6) a cada procedimento para conferir a exatidão dos resultados

\section{1 - Hidrólise enzimática e solubilização do amido não resistente (ANR)}

Pesar a amostra, previamente moída, em triplicata de $100 \mathrm{mg} \pm 5 \mathrm{mg}$ cada, em tubo para centrífuga de $50 \mathrm{~mL}$.

Adicionar 4,0 mL de solução de $\alpha$-amilase pancreática $(10 \mathrm{mg} / \mathrm{mL})$ contendo amiloglicosidase (3 U mL-1), recém-preparada.Tampar bem os tubos e vedar com parafilme.

Incubar em banho-maria a $37^{\circ} \mathrm{C}$ e $100 \mathrm{rpm}$, por 16 horas.

Retirar os tubos do banho-maria, adicionar 4,0 mL de álcool etílico $99 \%$ e agitar vigorosamente durante 15 segundos em agitador de tubos a $1.200 \mathrm{rpm}$.

Centrifugar a $3.000 \mathrm{x}$ g por dez minutos.

Retirar cuidadosamente o sobrenadante com auxílio de um pipetador de 5,0 mL e transferir para balão volumétrico de $100 \mathrm{~mL}$ (reservar para a determinação de amido não resistente).

Ressuspender o precipitado em $8,0 \mathrm{~mL}$ de álcool etílico $50 \%$ e agitar durante dez segundos em agitador de tubos $1.200 \mathrm{rpm}$.

Centrifugar a 3.000 x g por dez minutos. Retirar o sobrenadante, com cuidado para não suspender o precipitado e transferir para o balão volumétrico de $100 \mathrm{~mL}$ reservado para ANR. Repetir esta etapa.

Após a segunda lavagem com álcool etílico $50 \%$, colocar o tubo contendo o precipitado (amido resistente) na capela de exaustão para evaporar o álcool remanescente.

Nota: O precipitado será utilizado para a determinação do amido resistente (AR) e os sobrenadantes (reunidos) para a determinação do amido não resistente (ANR) ou amido solúvel.

\section{2 - Determinação do amido resistente (AR)}

Adicionar uma barra magnética dentro de cada tubo contendo o precipitado e colocar em banho de gelo sobre um agitador magnético. Em seguida, acrescentar, sob agitação, 2,0 mL de solução de hidróxido de potássio 2,0 mol L-1 e deixar sob agitação

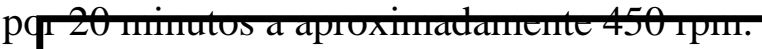

Nota: Verificar se todo o precipitado foi dissolvido, sem a formação de grumos.

Retirar as amostras do banho de gelo e, ainda sob agitação (aproximadamente 200 rpm) da placa, acrescentar 8,0 mL de tampão acetato de sódio 1,2 mol L-1 (pH 3,8).

Acrescentar $100 \mu \mathrm{L}$ de amiloglicosidase concentrada (3.300 U mL-1) e incubar em banhomaria a $50{ }^{\circ} \mathrm{C}$ por 30 minutos (agitar em agitador de tubos a cada dez minutos). 
Medir o volume final de cada réplica da amostra com o auxílio de pipeta graduada de vidro de 20,0 $\mathrm{mL}$ e anotar; retornar a solução para o tubo (normalmente o volume final é de $10,3 \mathrm{~mL}$ ).

Centrifugar a $3.000 \mathrm{x}$ g por dez minutos.

- Pipetar em duplicata $100 \mu \mathrm{L}$ do sobrenadante de cada réplica da amostra para tubos de ensaio.

- Preparar um branco com $100 \mu \mathrm{L}$ de tampão acetato de sódio 0,1 M (pH 4,5).

- Pipetar em triplicata $100 \mu \mathrm{L}$ do padrão D-glicose (Frasco 5) para tubos de ensaio.

Adicionar 3,0 mL de reagente GOPOD aos tubos contendo a amostra, o branco e o padrão glicose. Agitar em agitador de tubos a $1.200 \mathrm{rpm}$ por apenas cinco segundos.

Incubar em banho-maria a $50{ }^{\circ} \mathrm{C}$ por 20 minutos.

Medir a absorbância da amostra (AbsAR) e do padrão glicose (AbsGLI) em espectrofotômetro a $510 \mathrm{~nm}$.

Importante: Se a leitura de AbsAR for acima de 1,3000, o teor de AR da amostra será maior que $10 \%$ e poderá ocorrer erro pelo desvio da Lei de LambertBeer. Então será necessário efetuar uma diluição, transferindo todo o conteúdo do tubo, após tratamento com amiloglicosidase, para balão volumétrico de $100 \mathrm{~mL}$ e completando o volume com água destilada. Transferir uma alíquota de aproximadamente $10 \mathrm{~mL}$ para outro tubo de centrífuga de $50 \mathrm{~mL}$ e centrifugar, continuando com o procedimento anteriormente descrito.

\section{3 - Determinação do amido não resistente (ANR) ou solúvel}

Completar até $100 \mathrm{~mL}$, com tampão acetato de sódio 0,1 mol L-1 (pH 4,5), os balões volumétricos contendo os sobrenadantes obtidos da hidrólise enzimática e subsequentes lavagens com álcool etílico e homogeneizar.

Transferir alíquotas de $100 \mu \mathrm{L}$ em duplicata para tubos de ensaio, acrescentar $10 \mu \mathrm{L}$ amiloglicosidase diluída (300 U mL) e agitar manualmente.

Preparar um branco com $110 \mu \mathrm{L}$ de tampão acetato de sódio 0,1 mol L-1 (pH 4,5).

Incubar em banho-maria a $50{ }^{\circ} \mathrm{C}$ por 20 minutos.

Adicionar 3,0 $\mathrm{mL}$ do reagente GOPOD preparado e agitar em agitador de tubos a $1.200 \mathrm{rpm}$ por cinco segundos.

Incubar em banho-maria a $50{ }^{\circ} \mathrm{C}$ por 20 minutos.

Medir a absorbância das amostras (AbsANR) em espectrofotômetro a $510 \mathrm{~nm}$.

\section{- Cálculo}

Amido Resistente (g/100 g):

$\mathrm{AR}=(\operatorname{AbsAR}) \times(\mathrm{F}) \times(\mathrm{Vf} / 0,1) \times(1 / 1000) \times(100 / \mathrm{PS}) \times(162 / 180)$

$\mathrm{AR}=(\mathrm{AbsAR}) \times(\mathrm{F}) \times(\mathrm{Vf} / \mathrm{PS}) \times 0,90$ 


\section{Amido Não Resistente (g/100 g):}

ANR $=($ AbsANR $) \times(F) \times(100 / 0,1) \times(1 / 1000) \times(100 / P S) \times(162 / 180)$

$$
\mathrm{ANR}=(\mathrm{Abs} A N R) \times(\mathrm{F} / \mathrm{PS}) \times 90
$$

\section{Amido Total (g/100g):}

AT = Amido Não Resistente (g/100 g) + Amido Resistente (g/100 g)

Onde:

$\mathrm{F}$ = fator de conversão da absorbância do padrão glicose (AbsGLI) para microgramas

$\mathrm{F}=100 /$ (média das AbsGLI)

Vf = volume final medido da amostra no tubo ou $100 \mathrm{~mL}$ após diluição (para amostras com Abs acima de 1,3000 ou 10\% de AR)

$1 / 1000=$ conversão de microgramas para miligramas

$\mathrm{PS}=$ peso seco da amostra analisada

PS $=($ peso fresco das amostras $) \times(100-$ umidade $) / 100$

100/PS = fator para obter o resultado de AR e ANR em porcentagem $(\mathrm{g} / 100 \mathrm{~g})$

$162 / 180$ = fator de conversão da D-glicose livre obtida em D-glicose anidra (como ocorre no amido). 


\section{ANEXO VIII \\ Procedimento de Análise de Amido Amilose e Amilopectina}

\section{- Objetivo}

Determinação do teor de amilose e amilopectina através do método enzimático.

- Referências Normativas

Megazyme International Ireland. Amylose/Amylopectin. Assay Procedure - KAMYL09/14 disponível em: < www.megazyme.com >.

\section{- Materiais e equipamentos:}

Frasco volumétrico $(25 \mathrm{~mL})$

Tubos de ensaio de vidro (16 x $120 \mathrm{~mm}, 15 \mathrm{~mL})$ com tampa rosqueável

Micropipetas, de 50-1000 uL

Tubos Eppendorf $(2,0 \mathrm{~mL})$

Banho-maria a $95^{\circ} \mathrm{C}$

Balança analítica com a aproximação de $0,0001 \mathrm{~g}$

Agitador de tubos (vortex)

Centrífuga com capacidade de rotação de 14.000 x g

Espectrofotômetro UV/Visível operando a $510 \mathrm{~nm}$

Temporizador digital

Suporte para tubos

Balões volumétricos de 1,0 L, 2,0 L e $100 \mathrm{~mL}$

Béqueres de 2,0 L e 1,0 L

Barras magnéticas de $15 \mathrm{~mm}$ x $5 \mathrm{~mm}$

Tubo Falcon para centrífuga em polipropileno de $50 \mathrm{~mL}$

Parafilme

\section{- Reagentes e soluções:}

Acetato de sódio

Ácido acético Glacial

Azida sódica

Etanol 95\%

Cloreto de Sódio

Cloreto de cálcio di-hidratado

Cloreto de Magnésio hexahidratado

Cloreto de Manganês tetrahidratado

Dimetil Sulfóxido DMSO

Hidróxido de sódio

Kit para determinação de Amilose/Amilopectina (Megazyme) composto por: 
- Frasco 1 : Reagente Con A. Estável por $>5$ anos a $-20{ }^{\circ} \mathrm{C}$.

- Frasco 2: Amiloglucosidase [200 U em p-nitrofenilo $\beta$-maltósido ( i. e. $3.300 \mathrm{U}$ de amido a $\mathrm{pH} 4,5$, a $\left.40^{\circ} \mathrm{C}\right)$ ], mais $\alpha$-amilase fúngica $(500 \mathrm{U}$ de Reagente Ceralpha a pH 5,0 e $40^{\circ} \mathrm{C}$ ) , 2 ml. Estável por $>5$ anos a $4^{\circ} \mathrm{C}$.

- $\quad$ Frasco 3: Reagente Padrão GodPod . Tampão (50 mL, pH 7,4) , azida sódica e ácido p-hidroxibenzóico $(0,095 \%$ w/v). Estável durante > 4 anos a $4^{\circ} \mathrm{C}$.

- Frasco 4: GodPod Reagente enzimas. Congelar. Estável por > 5 anos $\mathrm{a}-20^{\circ} \mathrm{C}$.

- $\quad$ Frasco 5 : D-Glicose solução padrão (5 mL, 1,0mg/ml) em 0,2 \% (w/v) de ácido benzóico. Estável por > 5 anos à temperatura ambiente.

- Frasco 6: amostra de referência, Amido (com conteúdo especificado

- de amilose). Estável por $>5$ anos à temperatura ambiente.

\section{- Preparo das soluções:}

Tampão Acetato de Sódio (100 mM , pH 4,5):

Adicionar 5,9 mL de ácido acético glacial $(1,05 \mathrm{~g} / \mathrm{mL})$ a $900 \mathrm{ml}$ de água

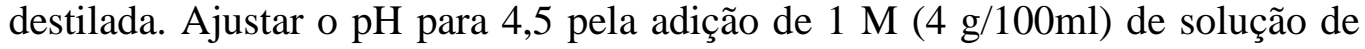
hidróxido de sódio (aprox. $30 \mathrm{ml}$ é necessário). Adicionar $0,2 \mathrm{~g}$ de azida de sódica e ajustar o volume a 1L. Estável por > 2 anos à temperatura ambiente.

Concentrado Con A Solvente (6,4 de sódio 600 mM, pH tampão de acetato)

Dissolver 49,2 $\mathrm{g}$ de acetato de sódio anidro, 175,5 g de cloreto de sódio, 0,5 $\mathrm{g}$ de $\mathrm{CaCl} 22 \mathrm{H} 2 \mathrm{O}, 0,7 \mathrm{~g}$ de $\mathrm{MgCl} 26 \mathrm{H} 2 \mathrm{O}$ e $0,7 \mathrm{~g}$ de $\mathrm{MnCl} 24 \mathrm{H} 2 \mathrm{O}$ em $900 \mathrm{~mL}$ de água destilada . Ajustar o $\mathrm{pH}$ para 6,4 por adição de ácido acético glacial e, em seguida ajustar o volume para 1L com água destilada. Estável durante 2 semanas a $4^{\circ} \mathrm{C}$.

NOTA: Ao preparar esta mistura tampão, é essencial que o pH seja ajustado muito cuidadosamente. Se o $\mathrm{pH}$ cair significativamente abaixo de 6,4 poderá formar um precipitado. Consequentemente, este reagente deverá ser descartado e um novo lote preparado.

Con A Solvente (concentração de trabalho)

Diluir $30 \mathrm{ml}$ do concentrado Con A solvente ajustado para $100 \mathrm{ml}$ com água destilada. Use no dia da preparação.

Reagente Com A:

Homogeneizar o conteúdo do Frasco 1 em 50,0 mL do Com A Solvente (concentração de trabalho). Dividir em alíquotas de $2,0 \mathrm{~mL}$ em tubos de polipropileno e congelar. Solução estável por cinco anos a $-20{ }^{\circ} \mathrm{C}$. 
Amiloglicosidase (AMG) diluída 300 U mL-1:

Homogeneizar 2,0 mL da amiloglicosidase concentrada (Frasco 2) em 20,0 $\mathrm{mL}$ de tampão maleato de sódio $(0,1 \mathrm{~mol} \mathrm{~L}-1, \mathrm{pH} 4,5)$, obtendo volume final de 22,0 mL. Dividir em alíquotas de 2,0 mL em tubos de polipropileno e congelar. Solução estável por cinco anos a $-20{ }^{\circ} \mathrm{C}$. Estável também durante repetidos ciclos de congelamento e descongelamento.

Reagente GOPOD (reagente de determinação de glicose)

Em balão volumétrico de 1,0 L, dissolver o conteúdo do Frasco 3 (concentrado para tampão) em água destilada e aferir o volume. Usar $20 \mathrm{~mL}$ desta solução para dissolver o conteúdo do Frasco 4 (reagente enzimas GOPOD) e, quantitativamente, transferir para béquer de 1,0 L contendo o restante da solução tampão para GOPOD, já diluída (usar a solução tampão para lavar o Frasco 4). Armazenar em frasco âmbar ou coberto por papel alumínio. Estável por três meses à temperatura de $2{ }^{\circ} \mathrm{C}$ a $5{ }^{\circ} \mathrm{C}$, ou por mais de 12 meses a $-20{ }^{\circ} \mathrm{C}$. Dividir em alíquotas antes de armazenar a $-20{ }^{\circ} \mathrm{C}$, pois, uma vez descongelada, a solução deve ser imediatamente usada. Quando recém-preparado, o reagente pode apresentar cor amarelo-claro ou rosa-claro. O reagente desenvolve coloração rosa-escuro após dois a três meses a $4{ }^{\circ} \mathrm{C}$. A absorbância desta solução deve ser menor que 0,05 quando lida a $510 \mathrm{~nm}$, usando água destilada como branco.

\section{- Procedimento}

Nota: É recomendável analisar uma amostra controle (Frasco 6) a cada procedimento para conferir a exatidão dos resultados

\section{1 - Pré-tratamento do amido}

Pesar a amostra, previamente moída, em triplicata de 20-25 mg $\pm 0,1 \mathrm{mg}$ cada, em tubo para centrífuga de $15 \mathrm{~mL}$.

Adicionar $1 \mathrm{ml}$ de DMSO ao tubo, agitando -o suavemente em baixa velocidade no vortex . Tapar o tubo e colocar em água fervente até que a amostra esteja completamente dissolvida (aprox. $1 \mathrm{~min}$ ).

Misture vigorosamente o conteúdo do tubo no vortex e coloca-lo em água fervente durante 15 min.

Deixar esfriar a temperatura ambiente por 5 min e adicionar $2 \mathrm{~mL}$ de $95 \%$ (v/v) de etanol. Agitar no vortex. Adicionar mais $4 \mathrm{ml}$ de etanol, tampar e voltar ao vortex. Um precipitado de amido vai se formar. Deixar descansar à temperatura ambiente por 15 minutos (ou durante a noite se necessário).

Centrifugar os tubos a 3.000 g por 10 minutos e desprezar o sobrenadante. Verter os tubos sobre papel absorvente por 10 min para certificar a completa remoção do etanol. Utilizar o sedimento na subsequente determinação de amilose e de amido. 
Adicionar $2 \mathrm{~mL}$ de DMSO ao amido sedimentar e agitar no vortex. Colocar o tubo em água fervente por 15 minutos. Certifique-se de que não existem pedaços gelatinosos.

Ao retirar os tubos do banho, imediatamente adicione $4 \mathrm{ml}$ de Con A solvente (concentração de trabalho), misture bem e, em seguida, transferir quantitativamente o conteúdo do tubo (por repetidas lavagens com Con A solvente), para um balão volumétrico de $25 \mathrm{~mL}$ (Solução A).

NOTA: Esta solução deve ser analisada dentro de $\mathbf{2}$ h.

\section{2 - Precipitação de amilopectina e determinação de amilose}

Transferir 1,0 mL da Solução A, para um Eppendorf de 2,0 ml. Adicionar 0,50 ml de reagente Con A. Tampar o Eppendorf e misturar delicadamente por inversão repetida. Evite a formação de espuma na amostra .

Deixar em repouso à temperatura ambiente durante $1 \mathrm{~h}$. Centrifugar a $14000 \mathrm{~g}$ durante 10 minutos em uma microcentrífuga.

Transferir $1 \mathrm{ml}$ do sobrenadante para um tubo falcon de $15 \mathrm{~mL}$. Adicionar $3 \mathrm{ml} \mathrm{de}$ tampão de acetato de sódio $100 \mathrm{mM}, \mathrm{pH} 4,5$. Este reduz o pH para 5. Misturar no vortex e aquecer em um banho de água fervente por 5 min para desnaturar a Con A.

Colocar o tubo em banho-maria a $40^{\circ} \mathrm{C}$ e deixar equilibrar durante $5 \mathrm{~min}$. Adicionar $0,1 \mathrm{ml}$ de enzima amiloglucosidase $/ \alpha$ - amilase e incubar a $40^{\circ} \mathrm{C}$ durante $30 \mathrm{~min}$. Centrifugar á $3.000 \mathrm{~g}$, durante $5 \mathrm{~min}$.

Retirar em triplicata alícotas de 1,0 mLdo sobrenadante e adicionar $4 \mathrm{ml}$ de GodPod Reagente. Incubar a $40^{\circ} \mathrm{C}$ durante $20 \mathrm{~min}$. Incubar um branco e os controles de Dglicose simultaneamente.

\section{NOTA:}

$O$ branco é preparado por adição de $1,0 \mathrm{~mL}$ de $100 \mathrm{mM}$ tampão de acetato de sódio a 4,0 $\mathrm{mL}$ de GodPod Reagente e incubando a $40^{\circ} \mathrm{C}$ durante $20 \mathrm{~min}$.

Os controles de D-glicose (em duplicata) compreendem $0,1 \mathrm{ml}$ de $D$ glucose solução padrão com $0,9 \mathrm{ml}$ de tampão de acetato de sódio e $4,0 \mathrm{ml}$ de GodPod reagente. Este valor não é utilizado no cálculo, no entanto, sugerem que ela é realizada para assegurar que não existem problemas com esta parte do ensaio.

Leia a absorvância de cada amostra e os controles de D-glucose a $510 \mathrm{~nm}$ contra o branco de reagente.

\section{3 - Determinação do amido total}

Misturar 0,5 ml da Solução A com 4 mL de acetato de sódio 100 mM tampão, pH 4,5 .

Adicionar $0,1 \mathrm{ml}$ de solução de amiloglucosidase/ $\alpha$-amilase e incubar a mistura a $40^{\circ} \mathrm{C}$ durante $10 \mathrm{~min}$.

Transferir 1,0 mL de alíquotas (em duplicata) desta solução para tubos de ensaio, adicionar $4 \mathrm{ml}$ de GodPod Reagente e misturar bem. Incubar a $40^{\circ} \mathrm{C}$ durante $20 \mathrm{~min}$. 
Esta incubação deve ser realizada simultaneamente com as amostras e os padrões de Seção B acima.

Leia a absorbância de cada amostra a $510 \mathrm{~nm}$ contra o branco de reagente.

\section{- Cálculo}

Amilose, \% (w/w):

(Absorbância Amilose / Absorbância Amido Total) x 66.8 


\section{ANEXO IX \\ Procedimento para Preparo de Extratos com Compostos Bioativos}

\section{- Referências Normativas}

Singleton, V. L., \& Rossi, J. A. (1965). Colorimetry of total phenolics with phosphomolybdic phosphotungstic acid reagents. American Journal of Enology and Viticulture, 16, 144-158.

\section{- Materiais}

Tubos falcon de $15 \mathrm{~mL}$

Tubos falcon de $50 \mathrm{~mL}$

Balão volumétrico de $50 \mathrm{~mL}$

Funil de $30 \mathrm{~mL}$

Vidro âmbar de $50 \mathrm{~mL}$

Pipetas automáticas com ponteiras de $10 \mathrm{~mL}$

- Preparo das soluções:

Solução metanol $70 \%$ acidificado com $1 \% \mathrm{HCl}$ :

Em balão volumétrico de $1 \mathrm{~L}$, adicionar $690 \mathrm{~mL}$ de álcool metílico; adicionar água destilada, depois adicionar $10 \mathrm{~mL}$ de ácido clorídrico e completar o volume para $1.0 \mathrm{~L}$ com água destilada, homogeneizar e transferir para um frasco de vidro devidamente etiquetado. Armazenar em temperatura ambiente por tempo indeterminado

Solução acetona $70 \%$

Em balão volumétrico de $1 \mathrm{~L}$, adicionar $700 \mathrm{~mL}$ de acetona; completar o volume para $1.0 \mathrm{~mL}$ com água destilada, homogeneizar e transferir para um frasco de vidro devidamente etiquetado. Armazenar em temperatura ambiente por tempo indeterminado.

\section{- Procedimento:}

Em um falcon de $15 \mathrm{~mL}$, pesar 0,5 g de amostra. Anotar o peso exato.

Adicionar $10 \mathrm{~mL}$ de metanol $70 \% 1 \% \mathrm{HCl}$, homogeinizar em mesa agitadora por 2 horas e manter em repouso overnight.

No dia seguinte, centrifugar a $4000 \mathrm{rpm}$ por 10 minutos.

Recolher o sobrenadante para um falcon de $50 \mathrm{ml}$.

Adicionar $10 \mathrm{~mL}$ de metanol $70 \% 1 \% \mathrm{HCl}$ ao resíduo da primeira extração (no falcon de $15 \mathrm{~mL}$ ).

Homogeinizar em mesa agitadora por 30 minutos. 
Centrifugar a $4.000 \mathrm{rpm}$ por 10 minutos e recolher o sobrenadante para o falcon de $50 \mathrm{~mL}$.

Repetir a extração com acetona $70 \%(10 \mathrm{~mL})$ duas vezes, totalizando quatro extrações.

Transferir o conteúdo do falcon de $50 \mathrm{~mL}$ para um balão volumétrico de $50 \mathrm{~mL}$ com auxílio de um funil. Avolumar com água destilada.

Transferir o conteúdo do balão para o vidro âmbar com o auxílio de um funil, filtrando o extrato com lã de vidro.

Manter o extrato congelado até o momento das análises. 


\section{ANEXO X \\ Procedimento para Análise de Fenólicos Totais}

\section{- Referências Normativas}

LARRAURI, J.A./ RUP[EREZ, P.; SAURA-CALIXTO, F. Effect of drying temperature on the stability of polyphenols and antioxidant activity of red grape pomace peels. J. Agric Food Chem. v.45, p. 1390-1393 (1997).

\section{- Materiais}

Espectrofotômetro com cubetas

Tubos de ensaio

Pipetas automáticas com ponteiras $(100 \mathrm{uL}, 1 \mathrm{~mL}, 10 \mathrm{~mL})$

\section{- Preparo das soluções:}

Solução de carbonato de sódio a $20 \%$

Pesar em um béquer de $100 \mathrm{~mL} 20 \mathrm{~g}$ de carbonato de sódio. Transferir para um balão de $100 \mathrm{~mL}$ com auxilio de 1 funil e de água destilada. Lavar o béquer 3 vezes com pequenas porções da água destilada. Completar o volume. Deixar descansar por 12 horas, filtrar e transferir para um frasco plástico. Armazenar em temperatura ambiente por tempo indeterminado.

\section{Folin-Ciocateau 1:3}

Em uma proveta, medir $50 \mathrm{~mL}$ do reagente Folin Ciocalteau e transferir para um frasco âmbar. Na mesma proveta, medir $150 \mathrm{~mL}$ de água destilada e acrescentar no mesmo frasco. Preparar no dia da análise.

\section{- Curva Padrão de Ácido gálico}

Todos os procedimentos devem ser feitos ao abrigo da Luz.

Pesar 0,01g de ácido gálico. Transferir cuidadosamente para um balão volumétrico de $100 \mathrm{~mL}$. Esta é a solução mãe $(100 \mu \mathrm{g} / \mathrm{mL})$. Avolumar com água.

A partir da solução mãe, preparar diluições em triplicatas variando a concentração de 10 a $100 \mu \mathrm{g} / \mathrm{mL}$. 
Tabela 1. Curva padrão de ácido gálico

\begin{tabular}{cccc}
\hline $\begin{array}{c}\text { Concentração } \\
(\mu \mathrm{g} / \mathrm{mL})\end{array}$ & $\begin{array}{c}\text { Solução de ácido } \\
\text { gálico }(\mu \mathrm{L})\end{array}$ & $\begin{array}{c}\text { Água destilada } \\
(\mu \mathrm{L})\end{array}$ & Abs média \\
\hline 10 & 500 & 4500 & 0,178 \\
20 & 1000 & 4000 & 0,360 \\
30 & 1500 & 3500 & 0,528 \\
40 & 2000 & 3000 & 0,685 \\
50 & 2500 & 2500 & 0,868 \\
60 & 3000 & 2000 & 1,033 \\
70 & 3500 & 1500 & 1,194 \\
80 & 4000 & 1000 & 1,313 \\
\hline
\end{tabular}

Pipetar em triplicata $1 \mathrm{~mL}$ de cada diluição.

Pipetar $1 \mathrm{~mL}$ da solução Folin em cada repetição e no branco $(1 \mathrm{ml}$ de água destilada)

Incubar por 1 minuto.

Adicionar 2,0 mL de carbonato de sódio a $20 \%$ e $2 \mathrm{~mL}$ de água destilada.

Incubar por 30 minutos a temperatura ambiente ao abrigo da luz.

Ler a absorbância a 700nm usar água destilada como branco.

Plotar em planilha as concentrações de ácido gálico $(\mu \mathrm{g} / \mathrm{mL})$ no eixo $\mathrm{X}$ e as respectivas absorbâncias no eixo $\mathrm{Y}$ e calcular a equação da reta.

Equação da reta: $y=0,0164 x+0,03, R^{2}=0,998$

\section{- Procedimento:}

Pipetar em triplicata $1 \mathrm{~mL}$ da amostra.

Pipetar $1 \mathrm{~mL}$ da solução Folin em cada repetição e no branco $(1 \mathrm{ml}$ de água destilada).

Incubar por 1 minuto.

Adicionar 2,0 $\mathrm{mL}$ de carbonato de sódio a $20 \%$ e $2 \mathrm{~mL}$ de água destilada.

Homogeneizar e incubar por 30 minutos a temperatura ambiente ao abrigo da luz.

Ler a absorbância a 700nm, usando água destilada como branco.

A partir das absorbâncias obtidas, substitui-las na equação (X) e obter o resultado $\mathrm{em} \mathrm{mg} / \mathrm{mL}$. 


\section{ANEXO XI \\ Procedimento para Análise de Taninos Totais}

\section{- Objetivo}

Determinação colorimétrica de proantocianidinas pelo método dmac.

\section{- Referências Normativas}

PRIOR, R.L.; FAN, E.; JI, H.; HOWELL, A.; NIO, C.; PAYNE, M.J.; REED, J. Multi-laboratory validation of a standard method for quantifying proanthocyanidins in cranberry powders. Journal of the Science of Food and Agriculture, v.90, p. 1473-1478, 2010.

\section{- Materiais}

Balão volumétrico de $10 \mathrm{ml}$.

Becker

Pipeta de $100 \mu \mathrm{L}$

Pipeta de $1 \mathrm{~mL}$

microplaca de poliestireno com 96 cavidades

Espectrofotômetro de microplaca

- Reagentes

Etanol absoluto

Padrão antocianidina B2

DMAC (4-dimethylsminocinnamaldehyde)

$\mathrm{HCl}$

\section{- Preparo das soluções}

Preparar solução DMAC $(0,1 \%)$

Pesar 50mg de reagente DMAC. Dissolver completando o volume com etanol em um balão de 50ml. Em um vidro ambar, adicionar 37,5ml desta solução com 6,25ml de a'gua destilada e $6,25 \mathrm{ml}$ de $\mathrm{HCl}$ (Adicionar o $\mathrm{HCl}$ na capela). Esta é a solução DMAC 0,1\% em etanol: água: ácido clorídrico (75: 12,5: $12,5 \mathrm{v} / \mathrm{v} / \mathrm{v})$.

\section{- Curva Padrão de Proantocianidina B2}

Pesar $1000 \mu \mathrm{g}(1 \mathrm{mg})$ de proantocianidina B2 e dissolver em etanol em um balão volumétrico de $10 \mathrm{ml}$ (esta é a solução mãe).

Fazer as diluições conforme tabela abaixo: 
Tabela 1. Curva padrão de procianidina

\begin{tabular}{cccc}
\hline $\begin{array}{c}\text { Concentração } \\
\text { (Proantocianidina) }\end{array}$ & $\begin{array}{c}\text { Solução de } \\
\text { Proantocianidin } \\
\text { a }(100 \mu \mathrm{g} / \mathrm{ml})\end{array}$ & $\begin{array}{c}\text { Volume de } \\
\text { etanol }(\mu \mathrm{L})\end{array}$ & $\begin{array}{c}\text { Absorbância } \\
\text { média }\end{array}$ \\
\hline 10 & 200 & 1800 & 0,178 \\
20 & 400 & 1600 & 0,360 \\
30 & 600 & 1400 & 0,528 \\
40 & 800 & 1200 & 0,685 \\
50 & 1000 & 1000 & 0,868 \\
80 & 1600 & 400 & 1,033 \\
100 & 2000 & 0 & 1,194 \\
\hline
\end{tabular}

Pipetar em triplicata $70 \mu \mathrm{L}$ de cada concentração e adicionar $210 \mu \mathrm{L}$ do reagente DMAC na microplaca de poliestireno com 96 cavidades.

Preparar o branco com $70 \mu \mathrm{L}$ de etanol e $210 \mu \mathrm{L}$ do reagente DMAC.

Colocar no espectrofotômetro de placa, aguardar 25 minutos e realizar leitura em espectrofotômetro a $630 \mathrm{~nm}$, zerando o equipamento com o branco.

Tabular dados para obter valor de $\mathrm{R}^{2}$ e equação da reta.

$$
y=0,016 x+0,038 R^{2}=0,998
$$

\section{- Procedimento}

Pipetar na microplaca de polietileno, em triplicata, $70 \mu \mathrm{L}$ de cada extrato e adicionar $210 \mu \mathrm{L}$ do reagente DMAC.

Colocar no espectrofotômetro de placa, aguardar 25 minutos e realizar leitura em espectrofotômetro a $630 \mathrm{~nm}$, zerando o equipamento com o branco.

A partir das absorbâncias obtidas, substitui-las na equação (X) e obter o resultado em $\mathrm{mg} / \mathrm{mL}$. 


\section{ANEXO XII \\ Procedimento para Análise da Atividade antioxidante por DPPH}

\section{- Referências Normativas}

BRAND-WILIAMS, W.; CUVELIER, M.E.; BERSET, C. Use of a free radical method to evaluate antioxidant activity. Food Science and Technology,Londres, v.28, p.25-30. 1995. Com modificações.

\section{- Preparo das soluções}

Solução de DPPH 0,06mM

Dissolver 2,4 mg de DPPH em álcool metílico e completar o volume para 100 $\mathrm{mL}$ em um balão volumétrico com álcool metílico, homogeneizar e transferir para um frasco de vidro âmbar, devidamente etiquetado. Preparar e usar apenas no dia da análise.

\section{- Curva Padrão de TROLOX}

Pesar $0,0125 \mathrm{~g}$ de Trolox em béquer de $10 \mathrm{~mL}$

Transferir quantitativamente (lavar o béquer com metanol 3 vezes) para balão de $50 \mathrm{~mL}$ (concentração de $998,84 \mu \mathrm{M}$ ) e completar o volume com metanol. Esta é a solução Mãe

Diluir a solução mãe para obter as concentrações da Tabela 1

Tabela 1: curva padrão de Trolox

\begin{tabular}{|c|c|c|c|}
\hline $\begin{array}{l}\text { Solução de Trolox } \\
(\mathrm{mL})\end{array}$ & $\begin{array}{l}\text { Solução de álcool } \\
\text { Metílico (mL) }\end{array}$ & Concentração $\mu \mathrm{M}$ & Abs média \\
\hline 0,25 & 3,75 & 50 & 0,662 \\
\hline 0,5 & 3,5 & 100 & 0,623 \\
\hline 1,0 & 3,0 & 200 & 0,551 \\
\hline 1,5 & 2,5 & 300 & 0,470 \\
\hline 2,0 & 2,0 & 400 & 0,402 \\
\hline 2,5 & 1,5 & 500 & 0,354 \\
\hline 3,0 & 1,0 & 600 & 0,272 \\
\hline 3,5 & 0,5 & 700 & 0,219 \\
\hline 4,0 & 0,0 & 800 & 0,172 \\
\hline
\end{tabular}

Cada diluição deverá ser pipetada e lida em triplicata 
Para cada concentração, pipetar $0,1 \mathrm{~mL}$ da diluição $+3,9 \mathrm{~mL}$ de solução DPPH $(0,06 \mathrm{mM})$, incubar pelo tempo determinado no EC50 e ler as absorbâncias.

Usar 4 cubetas, sendo 1 para o branco

BRANCO $=0,1 \mathrm{~mL}$ de água destilada $+3,9 \mathrm{~mL}$ de metanol

TUBO CONTROLE: $0,1 \mathrm{~mL}$ de água destilada e $3,9 \mathrm{~mL}$ de DPPH $0,06 \mathrm{mM}$. Ler a absorbância.

Para determinar a curva padrão de trolox, encontrar o \% de Inibição de cada diluição da solução mãe com o auxilio da equação abaixo:

$$
\% \text { Inibição }=(\text { AbsDPPH }- \text { Absconcentração }) \times 100
$$

Onde, AbsDPPH é a absorbância do tubo controle e Absconcentração é a absorbância média da concentração usada para construir a curva padrão. Realizar esse cálculo para todas as diluições.

Plotar as concentrações de Trolox no eixo $\mathrm{X}$ e os \% de inibição no eixo Y para encontrar a curva padrão.

$$
\text { Equação da reta: } y=0,098 x-1,485, R^{2}=0,996
$$

\section{- Determinação do tempo EC50}

Em ambiente escuro, transferir uma alíquota de $0,1 \mathrm{~mL}$ da diluição adequada do extrato para tubos de ensaio com $3,9 \mathrm{~mL}$ de DPPH $(0,06 \mathrm{mM})$ e homogeneizar em agitador de tubos.

Realizar leitura da absorbância da solução controle.

Utilizar álcool metílico, como branco, para calibrar o espectrofotômetro.

As leituras das absorbâncias $(515 \mathrm{~nm})$ devem ser monitoradas a cada cinco minutos, onde é observada a redução da absorbância até sua estabilização. A leitura da absorbância final para o cálculo do EC50 só deve ser feita após a estabilização da absorbância (tempo EC50). Neste caso, as leituras foram realizadas após 30 minutos.

Para experimentos posteriores, com uma mesma amostra, a leitura pode ser feita apenas no tempo estabelecido anteriormente (tempo EC50), acompanhado, também, da leitura inicial do controle.

\section{- Procedimento}

Pipetar $0,1 \mathrm{~mL}$ da amostra $+3,9 \mathrm{~mL}$ de solução DPPH $(0,06 \mathrm{mM})$, incubar pelo tempo determinado no EC50 (30 minutos) e ler as absorbâncias.

A partir da absorbância do tubo controle, determinar o \% de inibição do extrato. Utilizar o \% de inibição das amostras e a equação da reta de Trolox para encontrar a concentração de Trolox equivalente presente na amostra. 
A atividade antioxidante total (AAT) será expressa em $\mu$ mol de trolox equivalente/g de matéria fresca $(\mu \mathrm{mol}$ TE.g-1 MF).

\section{ANEXO XIII \\ Procedimento para Análise DA Atividade antioxidante Total por FRAP}

\section{- Referências Normativas}

PULIDO, R.; BRAVO, L.; SAURA-CALIXTO, F. Antioxidant activity of dietary as determined by a modified ferric reducing/ antioxidant power assay. Journal Agriculture and Food Chemistry, v. 48, p. 3396-3402, 2000.

\section{- Preparo das soluções}

Solução de $\mathrm{HCl}$ 40mM

Adicionar 3,34 mL de $\mathrm{HCl}$ concentrado em balão volumétrico de $1 \mathrm{~L}$ e completar o volume com água destilada. Homogeneizar e armazenar em temperatura ambiente por tempo indeterminado.

Solução de TPTZ 10mM

Pesar 312mg de TPTZ e avolumar em balão volumétrico de $100 \mathrm{~mL}$ com $\mathrm{HCl}(40 \mathrm{mM})$. Homogeneizar e armazenar sob refrigeração por até 1 mês.

Solução de Cloreto Férrico 20mM

Dissolver 540mg de cloreto férrico em água destilada, transferir para um balão volumétrico de $100 \mathrm{~mL}$ e completar até o volume final com água destilada. Homogeneizar e armazenar sob refrigeração por até 1 mês.

Tampão acetato $0,3 \mathrm{M}, \mathrm{pH} 3,6$

Em um béquer de $1000 \mathrm{~mL}$, dissolver 40,8 g de acetato de sódio em 16 $\mathrm{mL}$ de ácido acético glacial. Adicionar $800 \mathrm{~mL}$ de água destilada e verificar o pH em pHâmetro. Se necessário, ajustar pH com solução HCl 40mM. Transferir para um balão volumétrico de $1 \mathrm{~L}$ e completar o volume final com água destilada. Homogeneizar e armazenar sobre refrigeração por tempo indeterminado.

Solução de reagente FRAP

Preparar o Reagente FRAP no momento da análise.

$O$ reagente FRAP é obtido a partir da combinação: 
- $25 \mathrm{~mL}$ de tampão acetato $0,3 \mathrm{M}$

- $2,5 \mathrm{~mL}$ de solução TPTZ $10 \mathrm{mM}$

- $2,5 \mathrm{~mL}$ de solução aquosa de cloreto férrico $20 \mathrm{mM}$

\section{- Curva de calibração de TROLOX}

Pesar 0,01 g de Trolox em béquer de $10 \mathrm{~mL}$

Transferir quantitativamente (lavar o béquer com metanol 3 vezes) para balão de 50 mL (concentração de $800 \mu \mathrm{M}$ ) e completar o volume com metanol . Esta é a solução Mãe

Diluir a solução mãe para obter as concentrações da Tabela 1

Tabela 1: curva padrão de Trolox

\begin{tabular}{llll}
\hline $\begin{array}{l}\text { Concentração } \\
\mu \mathrm{M}\end{array}$ & $\begin{array}{l}\text { Solução de Trolox } \\
(\mathrm{mL})\end{array}$ & $\begin{array}{l}\text { Solução de álcool } \\
\text { Metílico }(\mathrm{mL})\end{array}$ & Abs média \\
\hline 50 & 0,25 & 3,75 & 0,058 \\
100 & 0,5 & 3,5 & 0,149 \\
200 & 1,0 & 3,0 & 0,286 \\
300 & 1,5 & 2,5 & 0,418 \\
500 & 2,5 & 1,5 & 0,655 \\
800 & 4,0 & 0 & 1,081 \\
\hline
\end{tabular}
de ensaio.

Transferir, em triplicata, uma alíquota de $90 \mu \mathrm{L}$ de cada concentração para tubos

Acrescentar $270 \mu \mathrm{L}$ de água destilada;

Misturar 2,7mL de reagente FRAP;

Homogeneizar e manter em banho-maria a $37^{\circ} \mathrm{C}$ por 30 minutos.

Realizar leitura a $595 \mathrm{~nm}$, utilizando o reagente FRAP como branco.

Plotar em planilhas as concentrações de Trolox $(\mu \mathrm{M})$ no eixo $\mathrm{X}$, e as respectivas absorbâncias no eixo Y e calcular a equação da reta;

$$
\text { Equação da reta: } \mathrm{y}=0,001 \mathrm{x}+0,013, \mathrm{R}^{2}=0,989
$$

\section{- Procedimento}

Todos os procedimentos devem ser realizados ao abrigo da luz.

Diluir os extratos conforme seja necessário.

Transferir uma alíquota de $90 \mu \mathrm{L}$ de cada diluição do extrato para tubos de ensaio (em triplicata)

Acrescentar $270 \mu \mathrm{L}$ de água destilada;

Misturar 2,7mL de reagente FRAP;

Homogeneizar e manter em banho-maria a $37^{\circ} \mathrm{C}$ por 30 minutos.

Realizar leitura a 595nm, utilizando o reagente FRAP como branco.

Para encontrar a concentração de trolox equivalente referente à atividade antioxidante por FRAP na diluição do extrato, substituir a média das absorbâncias de cada amostra na variável y da equação da reta da curva padrão. 
Os resultados da atividade antioxidante são expressos em $\mu$ Mol de Trolox equivalente/g. 


\section{APÊNDICE I}

Ficha técnica do pão sem glúten:

\begin{tabular}{|c|c|c|c|c|c|c|}
\hline INGREDIENTES & $\begin{array}{c}\text { PESO } \\
\text { BRUTO }(\mathrm{g})\end{array}$ & $\begin{array}{c}\text { PESO } \\
\text { LÍQUIDO(g) }\end{array}$ & FC & $\begin{array}{c}\text { PER } \\
\text { CAPITA }(g)\end{array}$ & $\begin{array}{l}\text { CUSTO TOTAL } \\
(\mathbf{R} \$)\end{array}$ & MODO DE PREPARO \\
\hline Farinha de sorgo & 122 & 122 & 1 & 10,2 & $6,54^{*}$ & \multirow{15}{*}{$\begin{array}{l}\text { Regenerar o fermento biológico seco por } \\
10 \text { minutos de pré-fermentação a } 40^{\circ} \mathrm{C} \text { em } \\
\text { água e açúcar. Em uma batedeira, com } \\
\text { uma ferramenta de pá (raquete) a uma } \\
\text { velocidade lenta (nível } 1 \text { e } 2 \text { ) misturar as } \\
\text { farinhas, a goma xantana, o sal, açúcar e } \\
\text { a gelatina. Adicionar a água morna junto } \\
\text { com o óleo. Posteriormente o ovo inteiro e } \\
\text { a clara foram adicionados até que a } \\
\text { mistura ficasse homogênea. Por último } \\
\text { adicionar o fermento levedado e misturado } \\
\text { em velocidade baixa. Quando a mistura } \\
\text { ficar homogênea colocar na formas } \\
\text { previamente untadas e deixar fermentar } \\
\text { em local morno por } 30 \text { minutos (até dobrar } \\
\text { de volume). Assar o pão em forno pré- } \\
\text { aquecido a } 200^{\circ} \mathrm{C} \text { e por } 30 \text { minutos. } \\
\text { Deixar esfriar, desenformar e servir. }\end{array}$} \\
\hline Fécula de batata & 56 & 56 & 1 & 4,72 & 1,43 & \\
\hline Polvilho doce & 22 & 22 & 1 & 1,81 & 0,22 & \\
\hline Gelatina em pó sem sabor & 2 & 2 & 1 & 0,17 & 0,20 & \\
\hline Goma xantanta & 2 & 2 & 1 & 0,17 & 0,44 & \\
\hline Açúcar mascavo & 16 & 16 & 1 & 1,33 & 0,15 & \\
\hline Sal & 2 & 2 & 1 & 0,17 & 0,00 & \\
\hline Óleo de Girassol & 15 & 15 & 1 & 1,25 & 0,10 & \\
\hline Água morna & 150 & 150 & 1 & 12,5 & - & \\
\hline Ovo inteiro & 77 & 66 & 0,86 & 5,50 & 0,60 & \\
\hline Clara de ovo & 32 & 32 & 1 & 2,67 & 0,30 & \\
\hline Fermento biológico seco & 5 & 5 & 1 & 0,42 & 0,27 & \\
\hline Açúcar mascavo (para fermento) & 5 & 5 & 1 & 0,42 & 0,05 & \\
\hline Água (para fermento) & 60 & 60 & 1 & 5,00 & - & \\
\hline \multicolumn{6}{|c|}{$\begin{array}{l}\text { Rendimento: } 472 \mathrm{~g} \\
\text { Fator de Cocção: } 0,85 \\
\text { VET: } 950 \text { kcal } \\
\text { CHO: } 66 \% \\
\text { PTN: } 11 \% \\
\text { LIP: } 23 \% \\
\text { Fibras (Total): } 21 \mathrm{~g} \\
\text { Porção: } 1 \text { fatia com aproximadamente } 39 \mathrm{~g} \\
\text { *Farinha de sorgo Comercial Importada }\end{array}$} & \\
\hline
\end{tabular}


